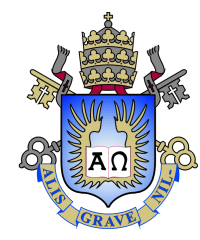

Victor de Rezende Cunha

\title{
Otimização de junção de topo de InGaP em células solares de junção tripla para aplicação espacial
}

Dissertação de Mestrado

Dissertação apresentada como requisito parcial para obtenção do grau de Mestre pelo Programa de Pós-graduação em Engenharia Elétrica do Departamento de Engenharia Elétrica do Centro Técnico Científico da PUC-Rio.

Orientador : Profa . Patrícia Lustoza de Souza Co-orientador: Prof. Daniel Neves Micha 


\section{Pontifícia Universidade Católica \\ DO RIO DE JANEIRO}

Victor de Rezende Cunha

Otimização da junção de topo de InGaP em células solares de junção tripla para aplicação espacial

Dissertação apresentada como requisito parcial para obtenção do grau de Mestre pelo Programa de Pós-Graduação em Engenharia Elétrica da PUC-Rio. Aprovada pela Comissão Examinadora abaixo assinada.

Prof.- Patrícia Lustoza de Souza

Orientadora

Centro de Estudos em Telecomunicações - PUC-Rio

Prof. Daniel Neves Micha

Co-Orientador

CEFET/RJ

Prof. Rodrigo Prioli Menezes

Departamento de Física - PUC-Rio

Prof. - Leila Rosa de Oliveira Cruz

IME

Prof. Márcio da Silveira Carvalho

Coordenador Setorial do Centro

Técnico Científico - PUC-Rio

Rio de Janeiro, 10 de outubro de 2018. 
Todos os direitos reservados. É proibida a reprodução total ou parcial do trabalho sem autorização do autor, da orientadora e da universidade.

\section{Victor de Rezende Cunha}

Formado em Bacharel em Nanotecnologia pela Universidade Federal do Rio de Janeiro (UFRJ) em 2016. Atua em pesquisa no LabSem PUC-Rio com semicondutores III-V para a produção de células solares. Faz parte da equipe de implementação da Sala limpa.

Ficha Catalográfica

Cunha, Victor de Rezende

Otimização de junção de topo de InGaP em células solares de junção tripla para aplicação espacial / Victor de Rezende Cunha ; orientador: Patrícia Lustoza de Souza ; co-orientador: Daniel Neves Micha. - 2018.

100 f. : il. color. ; $30 \mathrm{~cm}$

Dissertação (mestrado)-Pontifícia Universidade Católica do Rio de Janeiro, Departamento de Engenharia Elétrica, 2018.

Inclui bibliografia

1. Engenharia Elétrica - Teses. 2. Células solares. 3. Semicondutores. 4. Simulações. 5. Múltiplas junções. 6. Espacial. I. Souza, Patrícia Lustoza de. II. Micha, Daniel Neves. III. Pontifícia Universidade Católica do Rio de Janeiro. Departamento de Engenharia Elétrica. IV. Título. 
Para minha esposa, meus pais e irmão, pelo suporte e cuidado em todo o tempo. 


\section{Agradecimentos}

Primeiro eu agradeço a Deus, criador de tudo que existe. Obrigado pela vida, por poder estudar, trabalhar. Muito obrigado pelo cuidado e direção. Louvor e honra sejam dados a Ti.

A você minha maravilhosa esposa Livia. Muito obrigado por tudo, eu não consigo nem descrever o quanto eu sou grato a você por ter me ajudado tanto mesmo sem saber. Obrigado por estar ao meu lado, por cuidar de mim e ser compreensiva em tantos momentos. Você é um presente de Deus na minha vida e sou muito feliz por ter você ao meu lado. Te amo!!

Meus pais e meu irmão. Muito obrigado por serem minha base, meus modelos. Amo muito vocês e sem vocês eu não teria chegado tão longe. Obrigado pelo incentivo, pelo cuidado e pelas orações. Vocês são fundamentais na minha vida. Minha orientadora Patrícia muito obrigado por tudo. Não poderia ter tido uma pessoa melhor para me orientar. Obrigado por toda orientação, todas as dúvidas sanadas, todas as puxadas de orelha. Obrigado por ser uma pessoa tão íntegra, você é um modelo pra mim com certeza. Agradeço muito a Deus pela sua vida.

Meu co-orientador Daniel muito obrigado pela paciência, pelas discussões, pelos ensinamentos.

As minha tias, primas e primos que sempre tem sido tão presente na minha vida. Muito obrigado por cuidarem de mim. Vocês são maravilhosos. Meus sogros que também sempre apoiaram.

Rudy, cara não sei como te agradecer. Você foi excepcional no meu trabalho. Muito obrigado por toda ajuda com a montagem dos equipamentos, com as discussões sobre tantas coisas principalmente quanto a MOVPE. Desculpa ter te perturbado tanto. Valeu mesmo e como um símbolo da minha gratidão vou te dar uma coxinha.

Muito obrigado Mauricio, por toda ajuda que você me deu. Foi quase um orientador também.

Meus amigos do LabSem muito obrigado pela companhia, por tudo que aprendi com vocês.

Muito obrigado ao Pr. José e meus irmãos da IBPP. Que sempre estiveram presentes na minha vida e me apoiaram tanto.

Agradeço aos meus amigos que sempre estiveram ao meu lado, obrigado pela paciência.

Agradeço ao Prof. Sampaio e Renato do CBPF pelos fotorresistes que fizeram com que esse trabalho pudesse prosseguir. 
Agradeço aos Profs. Leila e Carlos do IME por terem disposto de tempo para tentarmos metalizar minhas amostras. Agradeço também aos alunos do IME que me ajudaram.

Agradeço muito ao Prof. Alain da USP, por ter me recebido, ter me permitido utilizar suas instalações e pelas dicas de processamento. Obrigado aos alunos do LNMS por terem me recebido tão bem e me ajudado em tudo que precisei. Agradeço à PUC-Rio e ao Departamento de Engenharia Elétrica pela oportunidade de fazer o mestrado.

O presente trabalho foi realizado com apoio da Coordenação de Aperfeiçoamento de Pessoal de Nível Superior - Brasil (CAPES) - código de financiamento 001. 


\section{Resumo}

Cunha, Victor de Rezende; de Souza, Patrícia Lustoza; Micha, Daniel Neves. Otimização de junção de topo de InGaP em células solares de junção tripla para aplicação espacial. Rio de Janeiro, 2018. 100p. Dissertação de Mestrado - Departamento de Engenharia Elétrica , Pontifícia Universidade Católica do Rio de Janeiro.

As células solares de junções múltiplas detém os atuais recordes mundiais de eficiência de conversão fotovoltaica. Uma dificuldade técnica que existe nestes dispositivos é que a corrente destes dispositivos é limitada pela menor dentre as geradas por cada uma das junções. No caso da célula solar de junção tripla de InGaP/InGaAs/Ge, a célula padrão para aplicações espaciais, a limitação é na célula intermediária. Existe uma proposta de uso de poços quânticos na junção para aumentar a corrente produzida pela célula intermediária, sendo assim, as outras junções pn que compõem a célula tripla precisam ser redesenhadas para que haja um casamento de corrente. O presente trabalho tem como objetivo apresentar um design otimizado para a célula solar de InGaP que é a junção pn do topo. O intuito é encontrar uma estrutura otimizada para o casamento de corrente através de simulações e fabricar a célula solar. As amostras foram crescidas em um reator de deposição epitaxial de metalorgânicos em fase de vapor e os dados utilizados no crescimento das camadas, a saber: espessura e dopagem, foram obtidos a partir das simulações realizadas. Para verificação da qualidade ótica, estrutural e elétrica das camadas crescidas, foram feitos experimentos de fotoluminescência, difração de raio-x e efeito Hall. São apresentadas curvas de resistividade obtidas pelo método da linha de transmissão, curva de corrente-tensão e eletroluminescência que dão um diagnóstico da qualidade do dispositivo produzido.

\section{Palavras-chave}

Células Solares; Semicondutores; Simulações; Múltiplas Junções; AM0; Espacial. 


\section{Abstract}

Cunha, Victor de Rezende; de Souza, Patrícia Lustoza (Advisor); Micha, Daniel Neves (Co-Advisor). Optimization of the top InGaP junction in triple junction solar cells for spatial applications. Rio de Janeiro, 2018. 100p. Dissertação de Mestrado Departamento de Engenharia Elétrica , Pontifícia Universidade Católica do Rio de Janeiro.

Multi-junction solar cells hold the current world records of photovoltaic conversion efficiency. A technical difficulty that exists in these devices is that the current of these devices is limited by the smaller of those generated by each of the joints. In the case of the triple junction solar cell of InGaP / InGaAs / Ge, the standard cell for spatial applications, the limitation is on the intermediate cell. There is a proposal to use quantum wells at the junction to increase the current produced by the intermediate cell, so the other $p n$ junctions that make up the triple cell need to be redesigned to have a current match. The present work aims to present an optimized design for the InGaP solar cell which is the top $p n$ junction. The intention is to find an optimized structure for the current matching through simulations and fabricate the solar cell. The samples were grown in a vapor phase epitaxial deposition reactor and the data used in the growth of the layers, namely thickness and doping, were obtained from the simulations. To verify the optical, structural and electrical quality of the grown layers, photoluminescence, x-ray diffraction and Hall effect experiments were performed. Resistivity curves obtained by the transmission line method, current-voltage curve and electroluminescence are presented, which give a diagnosis of the quality of the device produced.

\section{Keywords}

Solar Cell; Semiconductors; Simulations; Multiple Junctions; AM0; Spatial. 


\section{Sumário}

1 Introdução $\quad 17$

2 Aspectos teóricos $\quad 23$

2.1 Junção pn 23

2.2 Células solares 25

$\begin{array}{ll}2.3 \text { Modelagem eletrônica } & 27\end{array}$

2.4 Espectro solar 31

2.4.1 AM0 - Espectro extraterrestre $\quad 32$

2.5 Limite de eficiência 32

3 Simulações $\quad 33$

3.1 Programa 33

3.2 Método de solução 34

$\begin{array}{lll}3.3 & \text { Dados e estrutura } & 36\end{array}$

3.4 Otimização e resultados 37

3.4.1 Emissor - InGaP-n 39

3.4.2 Base - InGaP-p 40

3.4.3 Janela - AIGalnP-n 41

3.4.4 BSF - AIGalnP-p 42

4 Fabricação dos dispositivos $\quad 45$

4.1 Crescimento $\quad 45$

4.1.1 Metalorganics Vapor Phase Epitaxy $\quad 45$

$\begin{array}{ll}\text { 4.1.2 Difração de raios-X } & 49\end{array}$

4.1.3 Fotoluminescência $\quad 50$

4.1.4 Efeito Hall 52

4.1.5 Perfil eletroquímico de capacitância-tensão 53

4.2 Processamento $\quad 54$

$\begin{array}{lll}4.2 .1 & \text { TLM } & 59\end{array}$

4.3 Resultados 60

4.3.1 Crescimento 60

$\begin{array}{lll}\text { 4.3.2 Processamento } & 70\end{array}$

5 Caracterização do dispositivo $\quad \mathbf{7 4}$

$\begin{array}{lll}5.1 & \text { Técnicas de caracterização } & 74\end{array}$

5.1.1 Curva corrente vs tensão sob iluminação 74

$\begin{array}{ll}\text { 5.1.2 Curva corrente vs tensão no escuro } & 75\end{array}$

$\begin{array}{lll}5.1 .3 & \text { Eletroluminescência } & 76\end{array}$

$\begin{array}{lll}5.2 \text { Resultados } & 77\end{array}$

5.2.1 Curva corrente vs tensão sob iluminação 77

5.2.2 Curva corrente vs tensão no escuro 82

$\begin{array}{lll}5.2 .3 & \text { Eletroluminescência } & 85\end{array}$

$\begin{array}{lll}6 & \text { Conclusões e trabalhos futuros } & 87\end{array}$ 
$7 \quad$ Referências bibliográficas $\quad 89$

A Software de simulação $\quad 94$

B Processamento $\quad 99$ 


\section{Lista de figuras}

Figura 1.1 Evolução dos recordes de eficiências dos diversos

tipos de células solares ao longo do tempo.

Figura 1.2 Esquema de célula tripla e espectro solar.

Figura 1.3 Eficiências limites de células solar para diferente números de junções.

Figura 2.1 Representação dos tipos de impurezas em uma rede cristalina.

Figura 2.2 Esquema de formação da junção pn.

Figura 2.3 Curva característica de um diodo.

Figura 2.4 Representação de corrente em uma célula solar sob iluminação.

Figura 2.5 Diferente situações de operação de uma junção pn.

Figura 2.6 Circuito equivalente de uma célula solar.

Figura 2.7 Curva IV e curva de potência.

Figura 2.8 Influência dos efeitos resistivos

Figura 3.1 Fluxograma do algoritmo utilizado pelo SCAPS para resolver as equações.

Figura 3.2 Estrutura da célula escolhida para simulação.

Figura 3.3 Estrutura de camadas escolhida para otimização.

Figura 3.4 Densidade de corrente vs espessura de InGaP.

Figura 3.5 Resultados obtidos através do COMSOL.

Figura 3.6 Curva de Jsc vs Espessura do emissor.

Figura 3.7 Curva de Jsc vs Dopagem do emissor.

Figura 3.8 Resultado da simulação para a camada-p.

Figura 3.9 Resultado da simulação para a camada da janela.

Figura 3.10 Resultado da simulação para o BSF.

Figura 3.11 Representação da estrutura final definida através dos resultados das simulações. 
Figura 3.12 Curva JV obtida na simulação da estrutura final juntamente com as figuras de mérito obtidas.

Figura 4.1 Esquema simplificado do funcionamento do reator de MOVPE.

Figura 4.2 Representação das etapas do processo químico que ocorre na câmara do reator.

Figura 4.3 Gráfico clássico de optoeletrônica que relaciona o gap

dos semicondutores com o respectivo parâmetro de rede.

Figura 4.4 Esquema da montagem experimental utilizada na medida de difração de raio-x.

Figura 4.5 Representação de um difratograma genérico.

Figura 4.6 Representação esquemática da montagem utilizada na medição de fotoluminescência.

Figura 4.7 Preparação e configuração dos contatos seguindo o método de Van der Pauw.

Figura 4.8 Representação da montagem experimental utilizada para a medição de efeito Hall.

Figura 4.9 Célula eletroquímica utilizada para medidas de CV.

Figura 4.10 Resumo dos procedimentos de fotolitografia para os processos positivo e negativo.

Figura 4.11 Fotografia das máscaras utilizadas no processamento.

Figura 4.12 Padrão de pads utilizados para produzir os contatos para a medida de TLM.

Figura 4.13 Curva de resistência vs distância obtida a partir das curvas IV feitas.

Figura 4.14 Espectro de difração de raio-x de InGaP não dopado.

Figura 4.15 Descasamento vs razão gálio sobre grupo III para amostras crescidas de InGaP não dopado.

Figura 4.16 Concentração de dopantes vs razão do fluxo de dopantes sobre o grupo III para calibração da camada de InGaP tipo-n.

Figura 4.17 Descasamento vs razão do fluxo de gálio sobre o grupo III para calibração do InGaP tipo-p. 
Figura 4.18 Dopagem vs razão do fluxo de dopantes sobre o grupo III para calibração do InGaP tipo-p.

Figura 4.19 Defeitos na superfície da amostra final crescida.

Figura 4.20 Espectros de PL obtidos para amostras de InGaP-n.

Figura 4.21 Espectros de PL obtidos para amostras de InGaP-p.

Figura 4.22 Recorte do gráfico de gap vs parâmetro de rede.

Figura 4.23 Dopagem vs razão do fluxo de dopantes sobre grupo III para calibração do AlGaInP tipo-n.

Figura 4.24 Representação das amostras crescidas a partir da estrutura escolhida. Com modificação na camada do emissor.

Figura 4.25 Microscopia ótica das figuras de TLM obtidas através no processo de fotolitografia.

Figura 4.26 Perfis da altura corroída das camadas obtidos no perfilômetro mecânico.

Figura 4.27 Curva de resistência vs distância, obtidas a partir das medidas de TLM para o contato $n$.

Figura 4.28 Curva de resistência vs distância, obtidas a partir das medidas de TLM para o contato p.

Figura 5.1 Esquema da montagem utilizada para medir a curva IV.

Figura 5.2 Curva ilustrativa da corrente de escuro de uma célula solar com as indicações das regiões das resistências e os fatores de idealidade.

Figura 5.3 Esquema da montagem utilizada para obter as imagens de eletroluminescência.

Figura 5.4 Curva JV para a amostra produzida no LabSem.

Figura 5.5 Curvas JV de amostras processadas no LNMS.

Figura 5.6 Curva Jsc vs espessura de InGaP-n resultado de nova simulação realizada com o aumento da mobilidade da camada.

Figura 5.7 Curva JV referente a amostras 2-07-120 com as indicações das regiões onde foram calculadas Rs e Rsh.

Figura 5.8 Corrente de escuro da célula processada no LabSem. 
Figura 5.9 Corrente de escuro das células processadas no LNMS.

Figura 5.10 Eletroluminescência das células 1-08-60 e 2-04-80. 85

Figura 5.11 Eletroluminescência das células 1-10-60 e 2-10-80. 86

Figura A.1 Tela inicial do software SCAPS, onde são feitas as configurações gerais das condições nas quais o dispositivo ira operar.

Figura A.2 Nesta tela é possível adicionar as camadas que compõem a célula e configurar a natureza elétrica dos contatos.

Figura A.3 Nesta tela é possível configurar as características do material adicionado.

Figura A.4 Tela de apresentação do resultado da simulação.

Figura A.5 Nesta tela é possível configurar uma bateria de simulações.

Figura A.6 Nesta tela é possível configurar as figuras de mérito à serem gravadas durante a simulação.

Figura A.7 Tela onde são apresentados os resultados obtidos no record da simulação. 


\section{Lista de tabelas}

Tabela 4.1 Recorte da tabela periódica mostrando com materiais semicondutores.

Tabela 4.2 Nesta tabela estão apresentados os processos com os fotorresistes e máscaras correspondentes.

Tabela 4.3 Resultado da calibração da fotolitografia parte 1 .

Tabela 4.4 Resultado da calibração da fotolitografia parte 2 .

Tabela 4.5 Contatos metálicos produzidos.

Tabela 4.6 Resumo dos resultados do crescimento do material quaternário.

Tabela 4.7 Resumo dos resultados da calibração do crescimento do quaternário tipo p.

Tabela 4.8 Resumo dos resultados das calibrações.

Tabela 4.9 Melhores valores de resistências de contato obtidas através da medida de TLM.

Tabela 5.1 Figuras de mérito obtidas das células processadas no LabSem.

Tabela 5.2 Valores de resistências das amostras processadas no LabSem.

Tabela 5.3 Figuras de mérito das células processadas no LNMS.

Tabela 5.4 Resistências em série e shunt das amostras processadas no LNMS. 
1. Os céus proclamam a glória de Deus; o firmamento demonstra a habilidade de suas mãos.

2. Dia após dia, eles continuam a falar; noite após noite, eles o tornam conhecido. Não há som nem palavras, nunca se ouve o que eles dizem.

3. Ou não há discurso nem linguagem em que não se ouça sua voz.

4. Sua mensagem, porém, chegou a toda a terra, e suas palavras, aos confins do mundo. Deus preparou no céu uma morada para o sol. 5. Dela o sol irrompe como o noivo depois do casamento; alegra-se como o valente guerreiro em seu caminho.

6. O sol nasce numa extremidade do céu e realiza seu trajeto até a outra extremidade; nada pode se esconder de seu calor.

7. A lei do Senhor é perfeita e revigora a alma. Os decretos do Senhor são dignos de confiança e dão sabedoria aos ingênuos.

Davi, Salmos 19. 


\section{Introdução}

A demanda por energia elétrica aumenta constantemente, e até 2040 deve aumentar em aproximadamente 30\%(1). Diariamente somos bombardeados por cerca de $1367 \mathrm{Wm}^{-2}$, dos quais $70 \%$ estão disponíveis para utilização como fonte de energia térmica ou elétrica e $30 \%$ são refletidos pela nossa atmosfera(2). A energia solar, em comparação com outras fontes de energia, é abundante e sustentável, pois tem baixo impacto ambiental em sua produção, utilização e descarte. Além disso é totalmente capaz de fornecer energia suficiente para suprir a demanda de energia elétrica mundial(2). Tendo em vista a demanda a ser suprida e a capacidade de fornecimento energético do sol, a utilização de células solares (dispositivos fotovoltaicos) como conversores da energia luminosa em energia elétrica é considerada uma ótima alternativa(3).

Células solares são dispositivos eletrônicos formados por uma junção pn. As junções pn são camadas de materiais semicondutores que possuem dois tipos de impurezas: tipo- $p$ (ricas em buracos) e tipo- $n$ (ricas em elétrons). Quando duas camadas, cada uma com um tipo dessas impurezas, estão em contato, formam uma junção. E quando a junção é iluminada produz tensão e corrente elétricas, gerando uma potência elétrica que pode alimentar uma carga.

O fenômeno que acontece na interação da luz com junção é chamado de efeito fotovoltaico, que foi descoberto por Edmund Becquerel em 1839 (4). Esse processo acontece quando o fóton com energia maior ou igual ao gap do material semicondutor interage com a junção, sendo absorvido criando pares elétron-buraco que, por sua vez, são separados pelo campo elétrico interno existente na junção gerando uma corrente contínua.

A fim de padronizar a caracterização das células solares de acordo com sua aplicação, foram definidos espectros solares de referência com diferentes características: o ângulo de incidência e quantas atmosferas a radiação tem que passar até o dispositivo. Para aplicações terrestres são utilizados o AM1.5G e o AM1.5D, que são os espectros que atravessam a atmosfera com o ângulo de aproximadamente $48,2^{\circ}$. O primeiro considera a luz difusa e o segundo não. Já para aplicação espacial é utilizado como referência o espectro AM0, que não atravessa a atmosfera. Este também conhecido como espectro extraterrestre. 
A primeira célula solar moderna data de 1953, produzida por Calvin Fuller e Gerald Pearson, quando ambos trabalhavam nos Laboratórios Bell nos Estados Unidos. A eficiência dessa célula era em torno de 4\%. Na época era algo impressionante, pois um dispositivo fotovoltaico à base de selênio possuía eficiência abaixo de 1\% (4). Pouco tempo depois os cientistas, a partir de algumas melhorias, conseguiram produzir uma célula que tinha eficiência de aproximadamente $6 \%(5)$.

Em março de 1958 a primeira célula que saiu da Terra era uma junção pn de silício que possuía uma eficiência de 10\% (6). O módulo solar associado ao satélite Vanguard I possuía dois transmissores de rádio, um era alimentado utilizando energia solar, o outro era alimentado por baterias. O transmissor utilizando bateria funcionou apenas por 20 dias, porém o transmissor que utilizou uma célula solar funcionou até 1964, e acredita-se que o funcionamento falhou devido a problemas no circuito transmissor. Este feito provou o valor da utilização da energia solar em aplicações espaciais.(4)

As células solares se tornaram alvo de muitas pesquisas com o intuito de conseguir um dispositivo que pudesse atingir eficiências mais altas para que o custo de produção, que era muito alto, pudesse ser compensado. Em 1961 William Shockley e Hans J. Queisser demonstraram que com uma junção pn simples não seria possível atingir uma eficiência acima de $33 \%$ (7), onde os principais problemas pontuados foram: 1) apenas fótons com energia maior ou igual ao gap podem produzir corrente, logo, todo o resto é desperdiçado por transmissão; 2) a diferença entre a energia do fóton que incide com energia muito maior que o gap do material e a energia do gap se converte em calor em um fenômeno denominado termalização.

Para transpor este limite estabelecido por Shockley-Queisser foram propostas alternativas de composição de células solares que fossem mais eficientes. Algumas dessas alternativas são: Células Solares de Junções Múltiplas (Multiple Junction Solar Cell - MJSC)(8), Células Solares de Banda Intermediária(9), entre outras. As MJSC possuem um grande potencial de ultrapassar $46 \%$ de eficiência que é o atual record(10).

O Laboratório Nacional de Energias Renováveis (National Renewable Energy Laboratory - NREL), dos Estados Unidos da América, atualiza anualmente o gráfico da figura 1.1 onde estão mantidos todos os recordes de eficiências alcançados até hoje por todos os tipos de células solares. É possível perceber que as células solares mais eficientes da atualidade utilizam a tecnologia de junções múltiplas.

As MJSC são dispositivos compostos por duas ou mais junções $p n$, empilhadas, com o objetivo de coletar a maior porção do espectro solar, a 


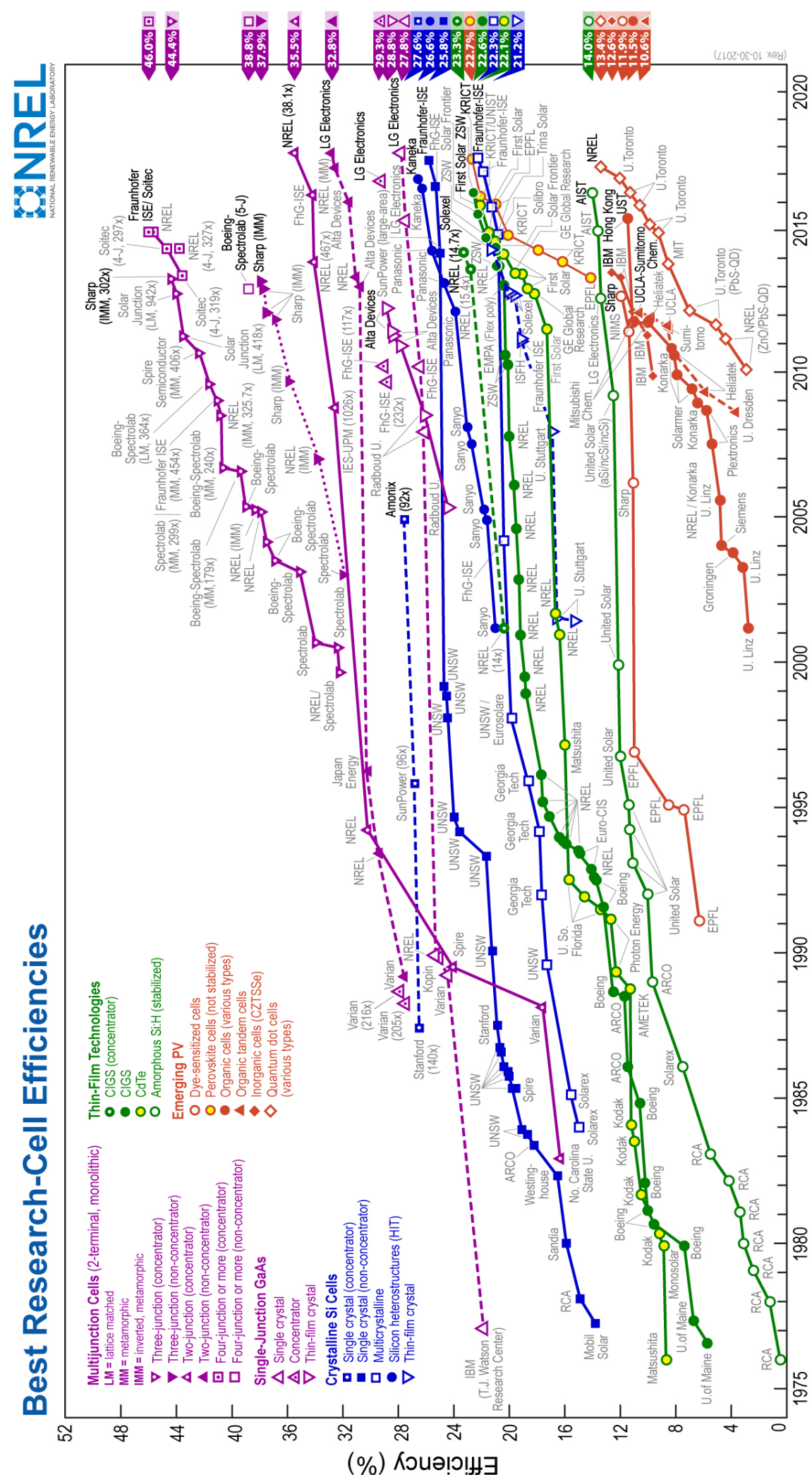

Figura 1.1: Evolução dos recordes de eficiência dos diversos tipos de células solares ao longo dos anos. Fonte: (11)

fim de minimizar os efeitos espectrais pontuados por Shockley-Queisser. Estão apresentados na figura 1.2 o espectro solar e o esquema de uma MJSC. Como 
pode ser observado cada célula que compõe a MJSC absorve em um intervalo específico de comprimentos de onda. Por ter três junções que compõem a sua estrutura, essa célula também é chamado de célula solar de tripla junção (TJSC do inglês Triple Junction Solar Cell).

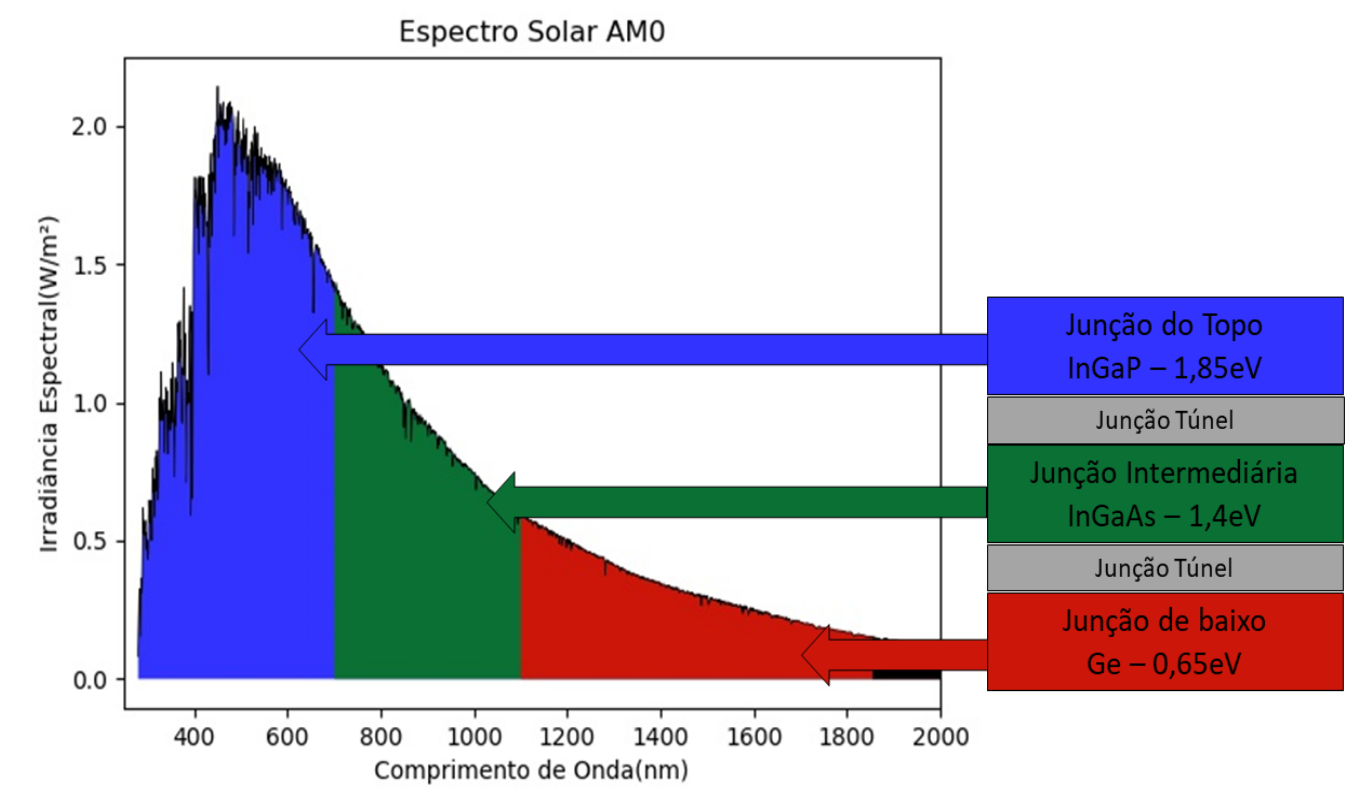

Figura 1.2: Esquema de uma célula de junção tripla e a faixa do espectro que cada uma das junções é capaz de coletar. Adaptado de (12)

Para atingir a máxima eficiência as células que compõem a TJSC precisam ter diversas características como: casamento dos parâmetros de rede dos materiais empilhados, equilíbrio na absorção dos fótons solares e, em particular para a aplicação espacial, resistência à radiação cósmica. O casamento dos parâmetros de rede é necessário para evitar a formação de defeitos pelo acúmulo de tensão na estrutura. O equilíbrio na absorção dos fótons pelas junções deve ocorrer para que todas gerem uma corrente elétrica similar, evitando perdas na conexão em série. Por fim, a resistência à radiação é importante, pois as partículas energéticas que existem no espaço provocam danos que degradam a eficiência dos dispositivos (13).

A TJSC utilizada por padrão em missões espaciais é composta pela célula de germânio (Ge) na base, pela célula intermediária de arseneto de gálio e índio (InGaAs) e no topo a célula de fosfeto de gálio e índio (InGaP). Estes materiais preenchem os requisitos de parâmetro de rede e resistência à radiação, porém falham no casamento da corrente, pois a célula de InGaAs não consegue fornecer a mesma corrente que as demais (14) e isto faz com que toda a corrente produzida pelo dispositivo seja limitada por ela. Para que o 
casamento de corrente ocorra é preciso que os gaps dos materiais que compõem o dispositivos sejam otimizados. Na figura 1.3 está apresentada um gráfico de otimização de eficiência em função da quantidade de junções de uma MJSC.

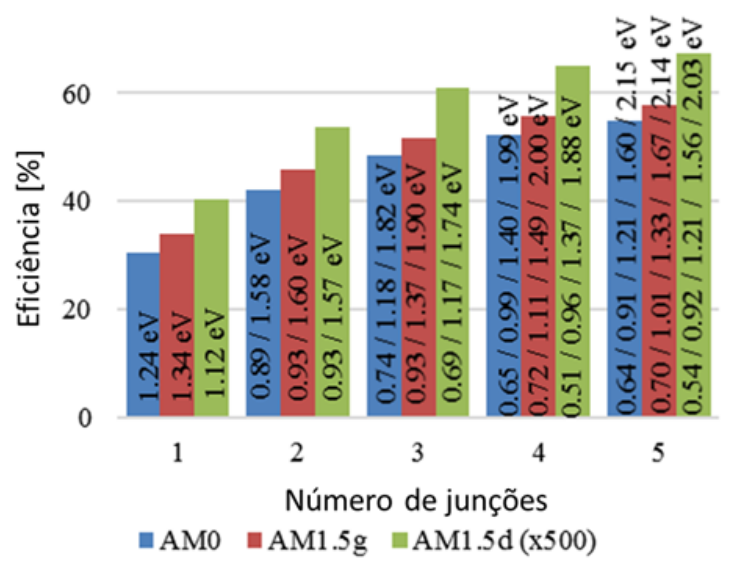

Figura 1.3: Eficiências limites de células solares de múltiplas junções para diferentes números de junções e espectros calculadas através do modelo de balanço detalhado.(15)

Como podemos observar para uma célula com três junções os gaps ótimos são 1,82 / 1,18 / 0,74. Como mencionado, os materiais ótimos para as junções do topo e inferior são contemplados pelo $\operatorname{In}_{0,5} \mathrm{Ga}_{0,5} \mathrm{P}$ e o $\mathrm{Ge}$, respectivamente. Porém, não existe material casado com estes com um gap de 1,18 eV. Para resolver o problema do gap da célula intermediária, existe uma proposta de uma nova configuração utilizando poços quânticos múltiplos de InGaAs/InGaP (16). Esta proposta implica em um aumento na corrente produzida pela célula intermediária. Consequentemente, as outras células precisam de um novo design otimizado para que haja o casamento de corrente e a eficiência do dispositivo todo seja melhorada.

A presente dissertação tem como objetivo apresentar um novo design otimizado para a célula de InGaP realizado através de simulações computacionais, para que haja o casamento de corrente entre todas as três células da tripla junção. Busca também apresentar o estudo dos materiais que compõem as camadas circunvizinhas à junção pn ativa, tais como a camada janela e a camada de Back Surface Field, responsáveis por otimizar a absorção dos fótons e transporte dos portadores até os contatos. Em particular, o material fosfeto de alumínio, índio e gálio (AlGaInP) foi utilizado por ser muito atrativo para aplicação em células solares como janela óptica devido a sua característica de ajuste do gap em uma composição que esteja com o parâmetro de rede casado com GaAs/Ge.

Inicialmente foram realizadas simulações com o intuito de encontrar valores de espessura e dopagem para as camadas que compõem o dispositivo 
a fim de produzir uma corrente maior para compor a nova formação da célula tripla. A partir dos valores encontrados nas simulações (espessura e dopagem), iniciou-se a produção das amostras com a calibração dos crescimentos que foram feitos, utilizando a técnica de MOVPE (crescimento Epitaxial usando MetalOrgânicos em Fase Vapor). A caracterização das amostras foi feita através das técnicas de fotoluminescência, difração de raios-x e medidas de efeito Hall. Tendo o dispositivo pronto, foi feito o processamento a fim de transformar o filme crescido em uma célula solar. A maior parte do trabalho foi desenvolvido no Laboratório de Semicondutores(LabSem) da PUC-Rio, a saber as simulações, crescimentos dos filmes, e as caracterizações. O processamento foi feito parte no LabSem e parte no laboratório de novos semicondutores (LNMS) da Universidade de São Paulo (USP).

Esta dissertação será dividida em seis capítulos, o primeiro sendo a introdução que apresenta o tema de células solares, a motivação e o objetivo do trabalho. O segundo capítulo trata dos aspectos teóricos estudados neste trabalho, onde são abordados os conceitos de junção pn, modelagem eletrônica do dispositivo e o espectro solar. No terceiro capítulo são apresentados: o processo de otimização da estrutura do dispositivo, resultados e as discussões a respeito das simulações. No capítulo quatro são apresentados os procedimentos experimentais para a fabricação do dispositivo. Neste capítulo passamos pelo processo de calibração do crescimento das amostras e o processamento do dispositivo, em sequência são apresentados os resultados e discussões desta etapa. No quinto capítulo são abordadas as técnicas utilizadas na caracterização dos dispositivos e os resultados e discussões pertinentes. Por fim o sexto capítulo traz as conclusões obtidas a partir dos resultados deste trabalho. 


\section{2}

\section{Aspectos teóricos}

Neste capítulo trataremos dos aspectos teóricos deste trabalho. Começaremos pela junção pn que é a parte fundamental para o funcionamento dos mais diversos dispositivos. Em seguida trataremos do funcionamento das células solares e como é feita a modelagem eletrônica. Por fim será apresentado o espectro solar utilizado neste trabalho e o limite teórico de eficiência.

\section{1}

\section{Junção pn}

A possibilidade de dopar diferentes regiões de materiais semicondutores com diferentes impurezas, permite a criação de uma grande variedade de dispositivos (17), por exemplo: transistores, diodos, etc. Esses dispositivos possuem uma base em comum que é a junção $p n$. Uma junção $p n$ é formada, quando um semicondutor que possui majoritariamente portadores de corrente do tipo- $p$ - os buracos - é produzido em contato com outro semicondutor que possui majoritariamente portadores de corrente do tipo- $n$ - os elétrons. Na figura 2.1 está representada uma rede cristalina simplificada com os dois tipos de dopagem.

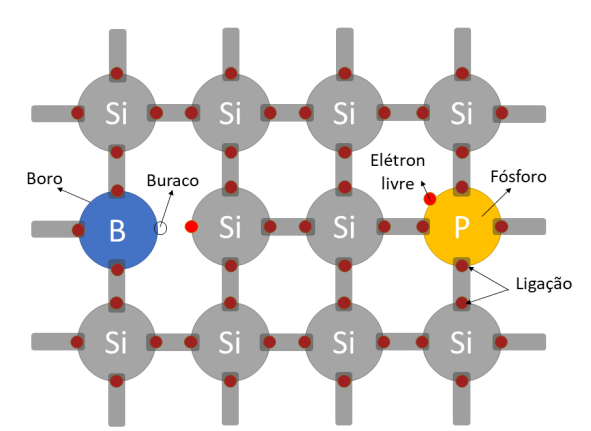

Figura 2.1: Representação dos tipos de impurezas em uma rede cristalina genérica de silício.

A figura 2.1 representa uma rede cristalina de silício, que faz quatro ligações. Ao inserir um átomo como o boro que possui 3 elétrons na camada de valência a região ficará deficiente de um elétron, pois o boro não completa as ligações de seus vizinhos. Este comportamento caracteriza o boro como uma 
impureza aceitadora. No caso da inserção do fósforo que, por possuir cinco elétrons na camada de valência, satisfaz as quatro ligações do Si e ainda lhe sobra um elétron, o qual pode ficar livre, assim aumentando a concentração de elétrons. Este comportamento caracteriza o fósforo com uma impureza doadora. Numa junção $p n$ as regiões com dopagens $p$ e $n$ são colocadas lado a lado, contíguas (13). Como é possível ver na figura 2.2, antes da junção ser formada, cada região está altamente concentrada com um tipo de portador.

Quando é feito o contato, elétrons se difundem para o lado $p$ e os buracos para o lado $n$ e essa tendência seria seguida até que suas concentrações fossem iguais em todo o material. Porém, ao se moverem deixam para trás cargas fixas, que por sua vez, vão gerar uma região que possui de um lado íons positivos e do outro íons negativos. Nessa região onde os íons estão presentes, gera-se um campo elétrico com direção de $n$ para $p$ que se contrapõe ao movimento das cargas, cessando a migração. Essa região é chamada de região de depleção, onde não existem portadores livres, pois todos são rapidamente retirados devido à ação do campo elétrico. Com o aparecimento deste campo, cria-se uma diferença de potencial na junção, essa tensão é chamada de barreira de potencial. Essa barreira de potencial previne a continuidade do transporte de portadores através da junção não polarizada.

(a)

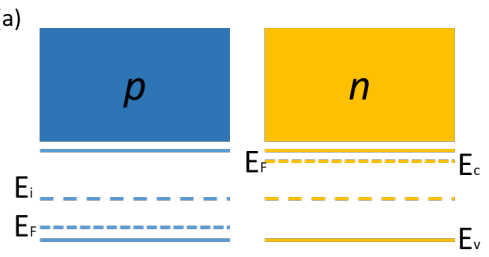

(b)

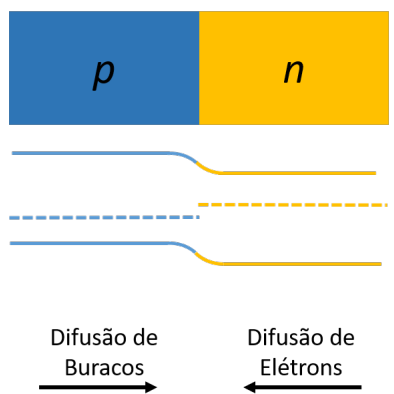

(c)

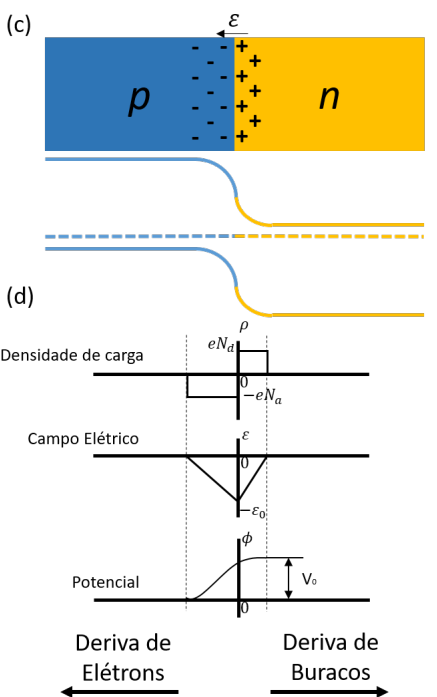

Figura 2.2: Formação de uma junção pn. Na parte (a) tem-se o momento que ainda não houve a junção. Em (b) é mostrado o instante em que é formada a junção e os portadores ainda estão apenas movimentando por difusão. Em (c) tem-se a junção completamente formada com a região de depleção, e os portadores já não têm mais apenas o movimento de difusão. Em (d) são apresentadas algumas das característica da junção, cargas, campo e potencial.

Aplicando um campo elétrico na junção pn obtemos o comportamento de diodo. Este comportamento é dado pela equação 2-1: 


$$
I=I_{0}\left(e^{\frac{q V a}{n k T}}-1\right)
$$

onde $I_{0}$ é a corrente de saturação do diodo, $\mathbf{q}$ a carga do elétron, $\mathbf{k}$ constante de Boltzmann, $\mathbf{T}$ temperatura e $\mathbf{V}_{a}$ tensão aplicada na junção.

Na figura 2.3 está apresentado a curva $I V$ característica do diodo.

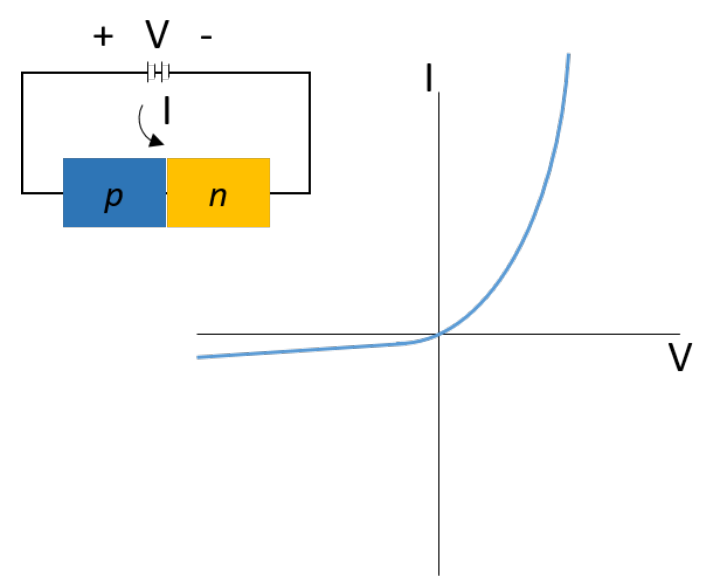

Figura 2.3: Curva de $I V$ característica de um diodo com uma incisão representando o circuito do diodo.

\section{2}

\section{Células solares}

Células solares são diodos semicondutores com a capacidade de absorver energia luminosa e uma porção dessa energia absorvida é convertida em energia elétrica (13). Quando uma célula está sob iluminação a curva $I V$ da figura 2.3 é deslocada do valor da fotocorrente gerada. A estrutura mais básica de uma célula é uma junção pn com contatos metálicos por onde é feita a coleta dos portadores. A figura 2.4 representa de forma básica o funcionamento de uma célula solar.

Quando um fóton cria um par elétron-buraco os portadores de carga sentem a influência do campo elétrico e são separados, sendo os buracos arrastados para o lado $p$ e os elétrons para o lado $n$. Esse fluxo de cargas define uma corrente na junção. O funcionamento de uma célula pode ser divido em três etapas:

1. A geração do par elétron-buraco devido à absorção da luz;

2. A separação dos portadores de carga devido ao campo elétrico gerado pela junção;

3. A coleta desses portadores de carga pelos respectivos eletrodos, esta- 


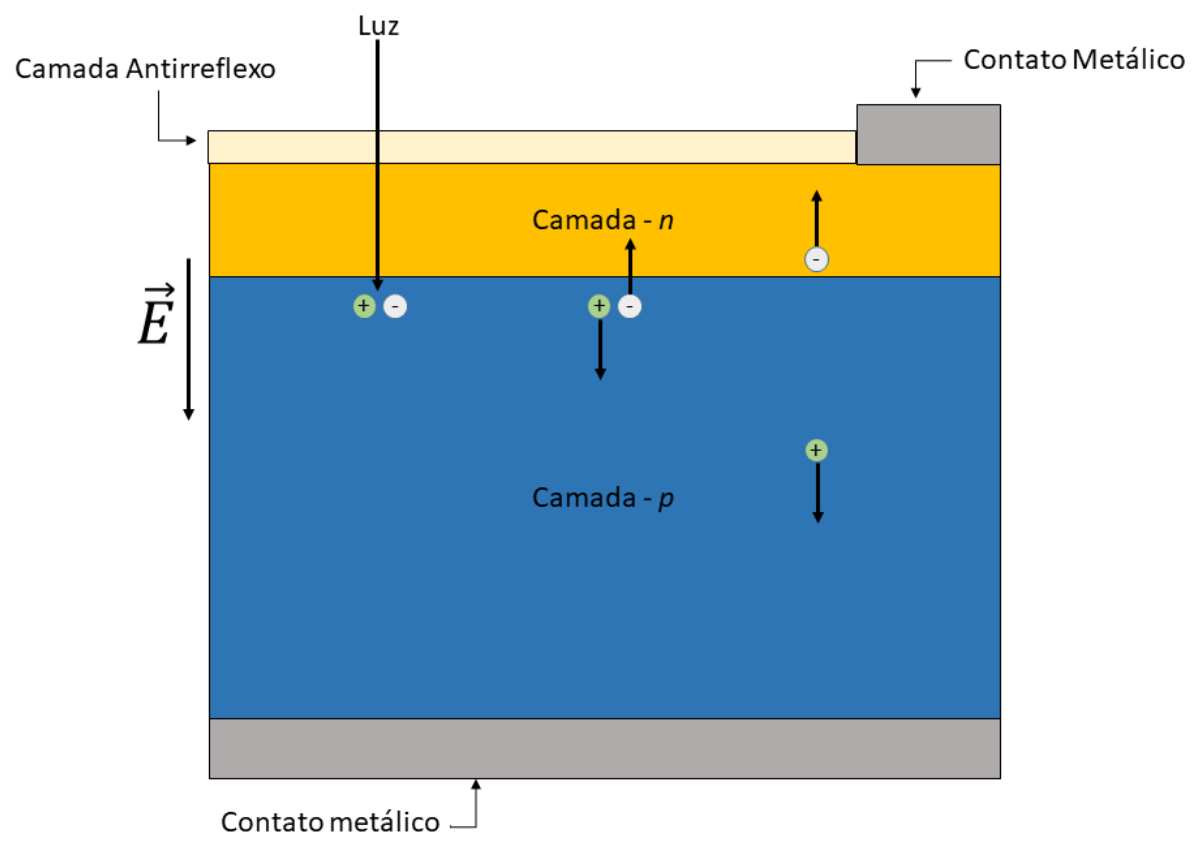

Figura 2.4: Representação da geração de corrente em uma célula solar sob iluminação.

belecendo uma corrente contínua.

A figura 2.4 é uma representação destas etapas. Os fótons absorvidos formam o par elétron-buraco, ou seja, excitam os elétrons da banda de valência para a banda de condução deixando um buraco na banda de valência. Esta formação por si só não gera corrente, pois o par pode se recombinar e emitir um fóton. Sem a ação de campo elétrico externo ou iluminação, os portadores estão em regime de equilíbrio na junção entre a corrente de difusão e deriva com o campo elétrico natural da junção. Sob iluminação, pares elétron-buraco são gerados e, na presença do campo elétrico intrínseco da junção pn, que vai do material $n$ para o $p$, são separados, gerando um fluxo de elétrons no sentido do lado $n$ para o lado $p$, ou seja, de um potencial menor para um potencial maior.

Na figura 2.5 temos a curva $I V$ da junção sob iluminação operando em três diferentes quadrantes.

Como podemos observar, em (a) e (b) temos o circuito externo fornecendo a potência para o dispositivo. Em (a) a corrente e tensão são positivas, a junção é polarizada diretamente e a corrente passa do maior potencial para o menor através da junção, de acordo com a figura 2.2(c). Em (b) a corrente e tensão são negativas, a junção é polarizada reversamente e a corrente flui do maior potencial para o menor. No entanto, em (c) não há polarização. No quarto quadrante é onde ocorre o funcionamento da célula solar, pois devido a tensão 

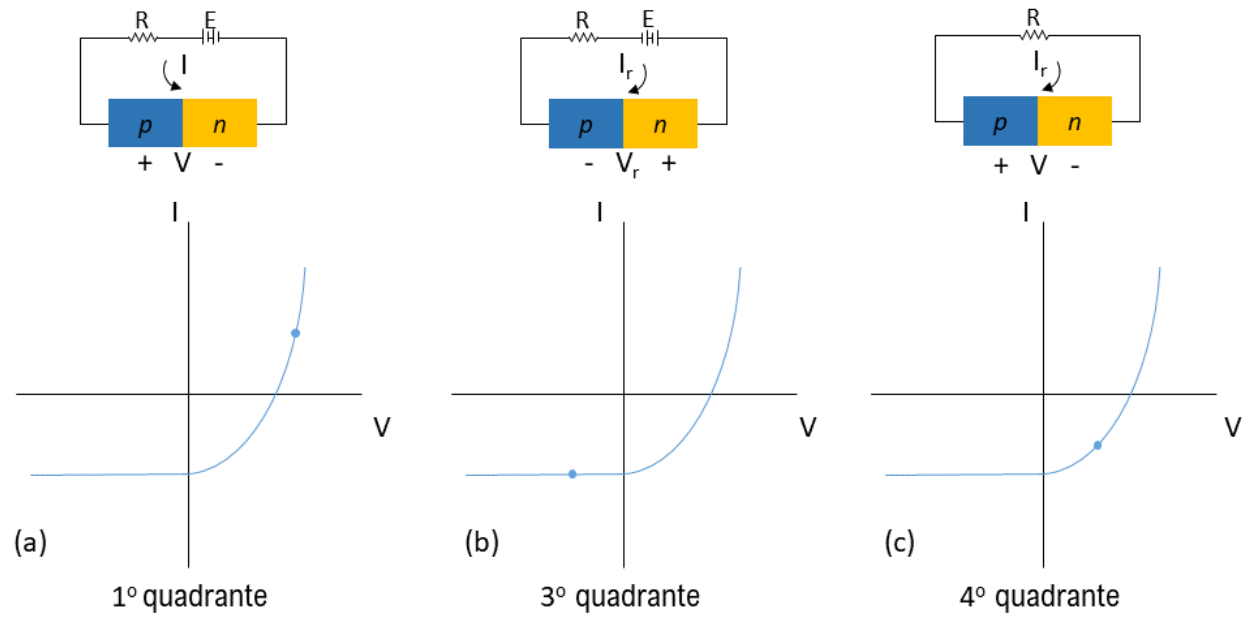

Figura 2.5: Junção pn operando sob iluminação em três diferentes quadrantes. Em (a) temos a curva $I V$ de uma junção $p n$ polarizada diretamente. Em (b) temos a curva $I V$ de uma junção pn polarizada inversamente. Em (c) temos a curva $I V$ de junção não polarizada. Adaptado de (18).

ser positiva e a corrente negativa esta característica faz com que a potência seja entregue ao circuito. Em (c) a corrente flui do menor potencial para o maior, ou seja, partindo da tensão negativa para um tensão positiva. Este comportamento é semelhante ao de uma bateria.

\section{3}

\section{Modelagem eletrônica}

O modelo utilizado para descrever o comportamento de uma célula solar, é um circuito equivalente com dois diodos em paralelo com uma fonte de corrente e a resistência shunt, tudo está em série com outra resistência que é chamada resistência em série como pode ser visto na figura 2.6.

A fonte de corrente representa a corrente gerada pela energia luminosa, o diodo 1 representa as recombinações nas regiões $p$ e $n$, o diodo 2 representa as recombinações na região de depleção, $\mathrm{R}_{s h}$ é a resistência shunt e $\mathrm{R}_{s}$ é a resistência em série. A corrente produzida por este circuito é dada pela equação $2-2$.

$$
I=I_{L}-I_{01}\left(e^{\frac{q\left(V+I R_{s}\right)}{k T}}-1\right)-I_{02}\left(e^{\frac{q\left(V+I R_{s}\right)}{2 k T}}-1\right)-\left(\frac{V+I R_{s}}{R_{s h}}\right)
$$

Onde: $\mathbf{I}_{L}$ é corrente da fonte de luz, $\mathbf{I}_{01}$ e $\mathbf{I}_{02}$ são as correntes de saturação dos diodos cujos fatores de idealidade são 1 e 2 respectivamente, $\mathbf{V}$ tensão gerada na saída do dispositivo. A célula solar ideal tem $\mathrm{I}_{02}$ e $\mathrm{R}_{s}$ iguais à zero e $\mathrm{R}_{s h}$ tendendo ao infinito. Porém, em uma célula real ocorrem muitas perdas 


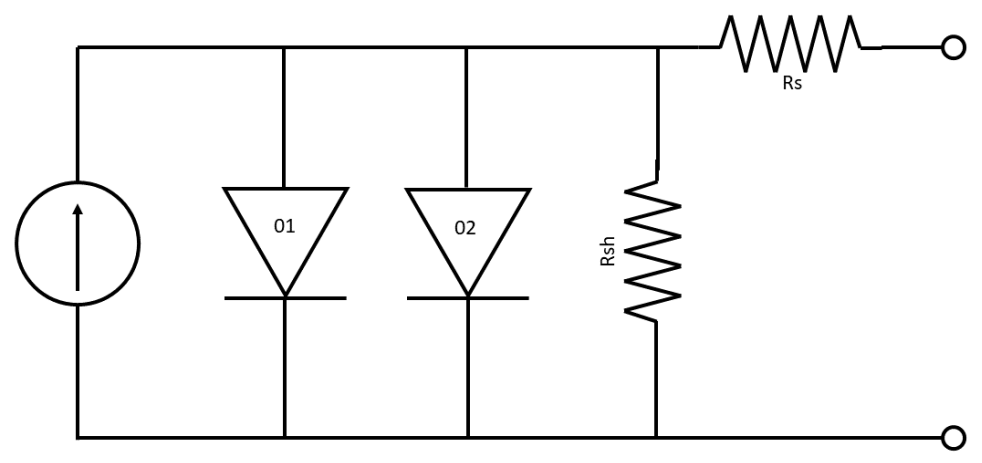

Figura 2.6: Circuito equivalente de uma célula solar. Onde a fonte de corrente representa a corrente fotogerada. Os dois diodos representam a junção e as regiões $p$ e $n$. E os efeitos de resistências estão representados pelas resistências em série e em paralelo. Adaptado de (19).

devidas ao processo de produção dos materiais e fabricação dos dispositivos. Frequentemente é mais conveniente escrever a equação 2-3.

$$
I=I_{L}-I_{0}\left(e^{\frac{q\left(V+I R_{s}\right)}{n k T}}-1\right)-\left(\frac{V+I R_{s}}{R_{s h}}\right)
$$

Onde $\mathbf{n}$ é o fator de idealidade entre 1 e 2 unificando os termos de recombinação em um diodo apenas com fator de idealidade $\mathbf{n}$.

Com a equação 2-3 é possível obter a curva corrente por tensão $(I V)$ que está apresentada na figura 2.7. A partir desta curva podem ser obtidas as figuras de mérito de uma célula solar.

Quando o dispositivo está sob iluminação, duas situações ocorrem: quando a corrente é zero, a condição é de circuito aberto, onde existe apenas uma diferença de potencial que é chamada de tensão de circuito aberto $\left(V_{o c}\right)$.

Quando a tensão é zero a situação é de curto circuito, a corrente é máxima e é chamada de corrente de curto circuito $\left(I_{s c}\right)$. Sob a condição de curto-circuito não há acúmulo de cargas, então os portadores podem ser coletados como uma corrente fotogerada.

A partir da curva $I V$ também obtemos o fator de preenchimento ( $F F$ do inglês Fill Factor) que é a razão entre a área do retângulo interno e a área do retângulo externo.

O FF pode ser calculado utilizando a equação 2-4 onde $I_{m p}$ e $V_{m p}$ são os 


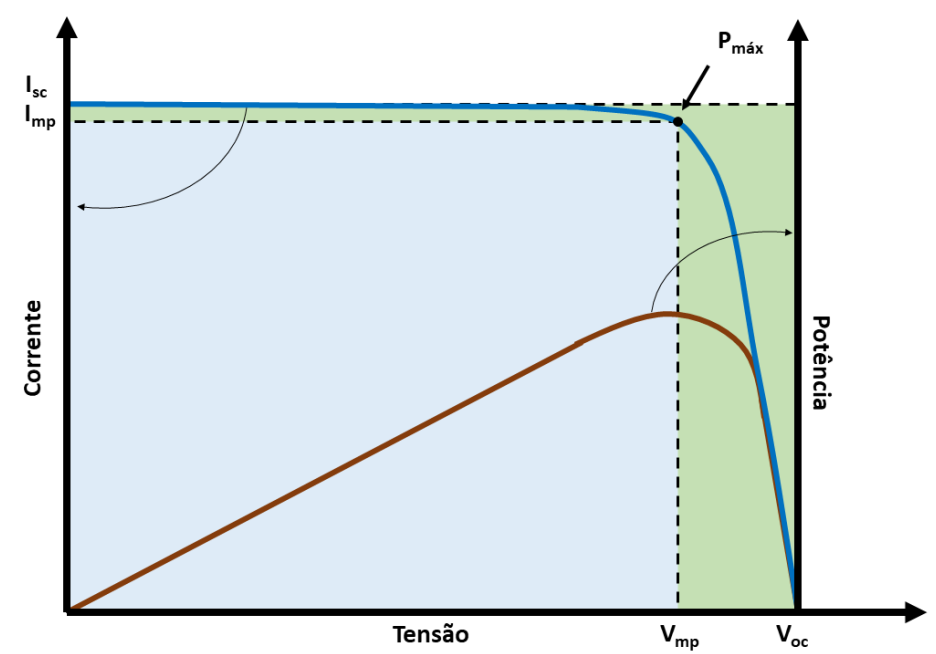

Figura 2.7: Curva característica de dispositivos fotovoltaicos. Em azul a curva $I V$ e em marrom a curva de potência fornecida.

pontos de corrente e tensão tais que geram máxima potência respectivamente. A potência máxima gerada pode ser calculada utilizando a equação 2-5. A curva marrom na figura 2.7 representa a curva de potência do dispositivo.

$$
\begin{aligned}
& F F=\frac{V_{m p} I_{m p}}{V_{o c} I_{s c}} \\
& P_{\text {máx }}=I_{s c} V_{o c} F F=V_{m p} I_{m p}
\end{aligned}
$$

Os valores de $I_{s c}$ e $V_{o c}$ podem ser obtidos através da equação 2-3 fazendo as considerações de curto circuito e circuito aberto.

$$
I_{s c}=I_{L}-I_{0}\left(e^{\frac{q\left(I_{s c} R_{s}\right)}{n k T}}-1\right)-\left(\frac{I_{s c} R_{s}}{R_{s h}}\right)
$$

$$
V_{o c}=\frac{n k T}{q} \ln \left(\frac{I_{s c}}{I_{0}}+1\right)
$$

A eficiência da célula é calculada pela razão entre o produto da potência máxima sobre a potência de luz incidente.

$$
\eta=\frac{P_{o u t}}{P_{\text {in }}}=\frac{I_{s c} V_{o c} F F}{P_{\text {in }}}
$$

Os componentes eletrônicos que compõem o modelo da célula solar possuem uma origem física. Os mecanismos de recombinação (diodos) e efeitos resistivos $\left(R_{s h}\right.$ e $\left.R_{s}\right)$ que serão explicados mais adiante impactam o funcio- 
namento da células. Os três principais tipos de recombinação são: Radiativa, Schockley-Read-Hall (SRH) e Auger.

Recombinação radiativa é o mecanismo oposto ao da geração, onde um elétron da banda de condução perde energia ao emitir um fóton e decai para a banda de valência recombinando com o buraco. Este é o mecanismo presente nos diodos emissores de luz (LEDs) e lasers.

A recombinação SRH acontece devido a defeitos na estrutura do material, e o processo ocorre em duas etapas. Inicialmente um elétron (ou buraco) cai em uma armadilha de um estado de energia da região proibida do gap, então, se um buraco (ou elétron) se mover para o mesmo estado de energia antes que o elétron seja termicamente reemitido para a banda de condução, ocorre ali a recombinação.

A recombinação Auger envolve três portadores. Inicialmente é similar à recombinação radiativa, onde o par é formado e recombina emitindo um fóton ou um fônon. Porém, ao invés desta energia sair do dispositivo ela é fornecida a um terceiro portador, no caso um elétron que será excitado para o topo da banda de condução e depois termalizará até a parte inferior da mesma banda.

As resistências shunt e em série são responsáveis pelos efeitos resistivos que também representam perdas. A resistência shunt representa as perdas por fuga provenientes de qualidade do processamento ou da produção do material, por exemplo.

Idealmente o valor da $\mathrm{R}_{s h}$ seria infinito, pois de acordo com o modelo eletrônico se essa resistência não for elevada, por aquele ponto do circuito haverá uma alternativa para a passagem da corrente. Menos corrente chegará até os terminais do dispositivo, acarretando uma perda na $\mathrm{V}_{o c}$. Na situação de tensões menores, os efeitos resistivos de $\mathrm{R}_{s h}$ causam ainda mais impacto no resultado da célula. A equação 2-9, obtida a partir da equação 2-3, expressa o efeito da $\mathrm{R}_{s h}$ na $\mathrm{V}_{o c}$, na situação de circuito aberto. E graficamente pode ser visto na figura 2.8 (a).

$$
\frac{V_{o c}}{R_{s h}}=I_{s c}-I_{0} e^{\frac{q V_{o c}}{n k T}}
$$

A resistência em série é composta por três condições: resistência do próprio material semicondutor, entre as camadas do dispositivo e entre o semicondutor e os contatos metálicos. No caso ideal, seu valor é nulo. A $\mathrm{R}_{s}$ afeta diretamente o FF. Porém para $\mathrm{R}_{s}$ com valores altos a corrente $\mathrm{I}_{s c}$ sofre uma redução. A equação 2-10 expressa o efeito da $\mathrm{R}_{s}$ na $\mathrm{I}_{s c}$, na situação de curto circuito. $\mathrm{O}$ efeito provocado pela $\mathrm{R}_{s}$ na curva $I V$ pode ser observado na 
figura 2.8 (b).

$$
I_{s c} R_{s}=\frac{n k T}{q} \ln \left(\frac{I_{0} e^{\frac{q V_{o c}}{n k T}}-I_{s c}}{I_{0}}\right)
$$
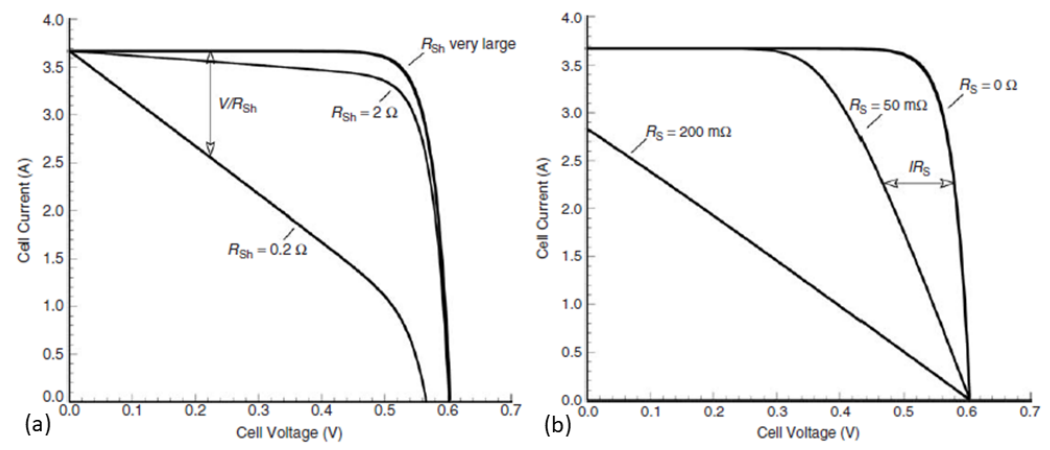

Figura 2.8: Influência dos efeitos resistivos na curva $I V$. A figura(a) mostra a influência da resistência shunt. A figura (b) mostra a influência da resistência em série. Fonte: (13)

\section{4}

\section{Espectro solar}

A equação 2-11 descreve a taxa de geração dos pares elétron-buraco.

$$
G(x)=(1-s) \int_{\lambda}(1-r(\lambda)) f(\lambda) \alpha(\lambda) e^{-\alpha x} d \lambda
$$

onde $\mathbf{s}$ é o sombreamento causado pelos contatos metálicos, $\mathbf{r}(\lambda)$ é a reflectância da superfície frontal, $\alpha(\lambda)$ é o coeficiente de absorção do material ativo e $\mathbf{f}(\lambda)$ é fluxo de fótons incidente (número de fótons incidentes por área por segundo por comprimento de onda).

O espectro solar utilizado define qual tipo de aplicação e condições a célula solar será submetida. A American Society for Testing and Materials (ASTM) padronizou os espectros para a caracterização das células solares. A massa de ar (AM - Air Mass) é o caminho óptico que a luz faz através da atmosfera. AM quantifica a perda de potência da luz quando passa pela atmosfera. A AM é definida através da equação 2-12.

$$
A M=\frac{1}{\cos (\theta)}
$$

onde $\theta$ é o ângulo de incidência em relação ao zenith (ângulo vertical). Quando o sol está no ponto mais acima AM é 1 . 


\subsection{1}

\section{AM0 - Espectro extraterrestre}

Identificar um espectro como espectro extraterrestre ou AM0 significa que não houve passagem por nenhuma massa de ar. Este é utilizado para aplicações espaciais. O espectro AM0 possui uma potência de $1366 \mathrm{Wm}^{-2}$, potência esta, maior que dos espectros que atravessam a atmosfera. Devido à interação com a atmosfera, ocorrem perdas de energia devido à absorção. Estas perdas ocorrem principalmente na região de mais altas energias (ultravioleta). O espectro AM0 é rico em ultravioleta e azul, ou seja, possui grande quantidade de fótons de maior energia. Por possuir um número de fótons maior, a utilização desse espectro faz com que a corrente produzida por uma célula solar seja maior. No entanto, a eficiência do dispositivo não é necessariamente maior, ela tende a ser menor devido à maior quantidade de termalização existente no dispositivo.

\section{5}

\section{Limite de eficiência}

Os efeitos espectrais são grandes fatores limitantes para que a eficiência dos dispositivos fotovoltaicos possa ser maior. Schokley-Queisser descreveram os efeitos limitantes para a eficiência de uma junção $p n$ simples (7). No limite do balanço detalhado eles fazem as seguintes colocações:

- Qualquer material acima do zero absoluto emite radiação. Por isso, uma célula à temperatura ambiente já está perdendo energia, reduzindo assim a eficiência do dispositivo.

- A absorção de um fóton gera um par elétron-buraco, que pode gerar uma corrente elétrica. No entanto, existe também o efeito oposto que entra no chamado balanço detalhado, onde um par elétron-buraco pode se recombinar emitindo um fóton. Isso também acaba por reduzir a eficiência.

O modelo de Schokley-Queisser aplicado a células de múltiplas junções, resulta no gráfico de barras de eficência por número de gaps que foi apresentado na figura 1.3. 


\section{3}

\section{Simulações}

Este capítulo trata sobre as simulações e o processo de otimização realizado. Serão apresentados os resultados obtidos pelo SCAPS, bem como alguns resultados obtidos através do COMSOL.

\section{1}

\section{Programa}

Começamos a utilizar o COMSOL Multiphysics (20). Este é um programa multipropósito, ou seja, serve para os mais diversos tipos de simulações. Também é possível utilizá-lo para células solares, pois possui um módulo que trata de semicondutores. Algo interessante sobre o COMSOL é que, por ser multipropósito, é possível montar as simulações inserindo funções e aplicando diversas condições, característica essa que outros softwares não permitem.

As simulações inicialmente foram realizadas no COMSOL, e isso foi de grande aprendizado, devido à necessidade de implementar equações para tratar o modelo da célula solar. No entanto o COMSOL não foi utilizado no processo de otimização, por conta de alguns problemas com o tratamento da luz na interação com o semicondutor. Seria possível resolver esse problema com o auxílio do suporte técnico, no entanto, para isso havia a necessidade de comprar uma nova licença, o que não foi possível devido ao alto custo da mesma e falta de recursos no momento da pesquisa. As simulações foram transferidas para o SCAPS, programa utilizado para encontrar a estrutura otimizada. Esse software foi desenvolvido no Departamento de Eletrônica e Sistemas de informação (ELIS) da Universidade de Gent na Bélgica (21).

SCAPS é um acrônimo para Simulador de Capacitância de Células Solares (Solar Cell Capacitance Simulator do inglês). É um software voltado para simulação de células solares e, por isso, ele possui ferramentas já implementadas que retornam os resultados da maneira mais conveniente na apresentação das figuras de mérito, etc. O software foi desenvolvido por: Alex Niemegeers, Marc Burgelman, Koen Decock, Stefaan Degrave, Johan Verschraegen, continua mantido por Marc Burgelman, e está disponível no site ${ }^{1}$ da universidade. O software tem licença livre para utilização, por isso é aberto à comunidade

\footnotetext{
${ }^{1}$ Disponível em <http://scaps.elis.ugent.be/>
} 
científica. Inicialmente o programa foi desenvolvido para simulação de células da família de $\mathrm{CuInSe}_{2}$ e CdTe. No entanto, recentes upgrades do programa, permitem a sua aplicação em células solares cristalinas (família de Si e GaAs) e amorfas (a-Si e Si micro-amorfo) (21). O software é de fácil utilização, permite uma configuração detalhada do modelo a ser simulado. Além disso oferece uma diversidade de resultados: curvas $J V$, figuras de mérito, eficiência quântica externa, etc. No apêndice A está uma breve apresentação do software.

\section{2}

\section{Método de solução}

O funcionamento de dispositivos semicondutores é descrito pelas chamadas equações dos semicondutores. Esse conjunto de equações é composto pela equação de Poisson, apresentada na equação 3-1, e pelas equações de continuidade, apresentadas na equação 3-2 (apresentadas de forma unidimensional para compatibilidade com o programa):

$$
\begin{gathered}
\frac{\partial E}{\partial x}=\frac{-q}{\varepsilon}\left(p(x)-n(x)+N_{D}^{+}-N_{A}^{-}\right) \\
\left\{\begin{array}{l}
-\frac{\partial j_{n}}{\partial x}+G-U_{n}(n, p)=0 \\
-\frac{\partial j_{p}}{\partial x}+G-U_{p}(n, p)=0
\end{array}\right.
\end{gathered}
$$

onde $q$ é a carga do portador, $\epsilon$ é a permissividade do material, $\boldsymbol{p}, \boldsymbol{n}(\mathbf{x})$ são as densidades dos portadores em $x$ e $\mathbf{N}_{D}$ e $\mathbf{N}_{A}$ são as concentrações dos dopantes doadores e aceitadores respectivamente, $j$ é a densidade de corrente para cada portador $(n, p), \mathbf{G}$ é o termo de geração dos pares e $\mathbf{U}$ é o termo que contém todas as recombinações. Esta equação é igual a zero, pois o cálculo feito não considera variação da concentração dos portadores no tempo.

Para tratar do transporte dos portadores essas equações são resolvidas para as correntes de difusão e deriva de buracos e elétrons apresentadas na equação 3-3:

$$
\left\{\begin{array}{l}
J_{n, p}=-q D_{n, p} \frac{\partial d_{n, p}}{\partial d x} \\
J_{n, p}=-q \mu_{n, p} n, p(x) E
\end{array}\right.
$$

Onde $\mathbf{D}$ é coeficiente de difusão para cada portador, $\mu$ é a mobilidade do portador. 
A partir dessas equações é possível modelar um dispositivo. O SCAPS resolve essas equações utilizando o método de iterações de Gummel com subpassos de Newton-Raphson em situação de steady state (que não varia no tempo).

Devido ao acoplamento entre as equações (3-1 e 3-2), o método de iteração de Gummel (23) é uma estratégia de solução onde o próprio programa faz um palpite inicial para solução da equação de Poisson. O método de Gummel tem bons resultados de convergência, se o palpite inicial for próximo de um valor aceitável, caso contrário a simulação divergirá, o que constitui um problema. O SCAPS utiliza em conjunto com método de Gummel, o método de Newton-Raphson (23). Esse método faz a parte numérica que de fato resolve uma matriz para os valores de $\phi, n$ e $p$.

O SCAPS não solicita ao usuário inserir um palpite inicial, ele o obtém através do cálculo das seguintes situações: o sistema em equilíbrio e no escuro e a corrente de curto circuito, com o resultado desses cálculos, inicia a solução do sistema de equações. Na figura 3.1 está apresentado o fluxograma do procedimento adotado pelo SCAPS para realizar uma simulação.

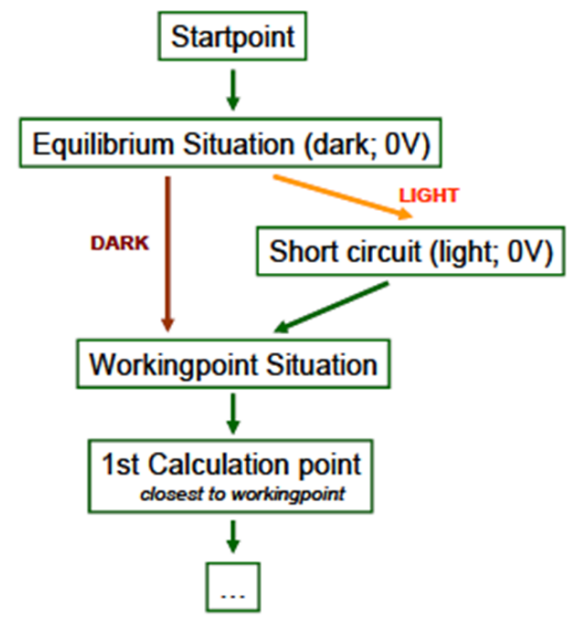

Figura 3.1: Fluxograma do algoritmo utilizado pelo SCAPS para resolver as equações. Fonte: (22)

Para resolver a interação da luz com o material, o SCAPS utiliza a equação 2-11 para calcular a geração dos pares elétron-buraco e utiliza a equação 3-4 para interagir os fótons provenientes do espetro com as camadas do dispositivo. O SCAPS não possui apenas espectros solares, mas também possui outros arquivos, como corpo negro e luz monocromática dentro do seu banco de dados. Este é o modelo de transição padrão do programa. Entretanto, é possível utilizar outros modelos de transição. 


$$
\alpha(\lambda)=\left(A+\frac{B}{h \nu}\right) \sqrt{h \nu-E_{g}}
$$

Onde A e B são constantes de absorção.

\section{3}

\section{Dados e estrutura}

Os dados dos materiais utilizados para modelar a célula foram obtidos de diversas fontes $(24,25)$. E como ponto de partida utilizamos a estrutura publicada por Takamoto et al (26). A estrutura da célula solar escolhida como base para as simulações está apresentada na figura 3.2.

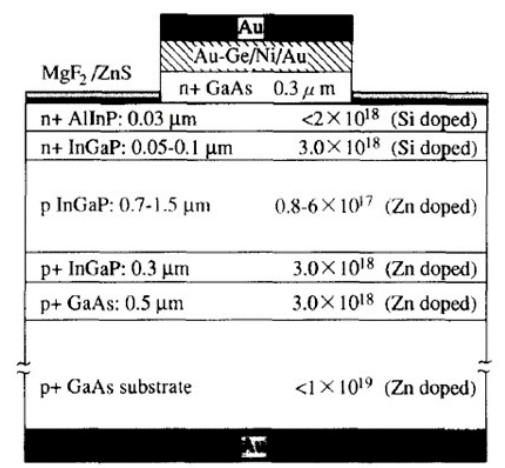

Figura 3.2: Estrutura da célula escolhida como base para simulação. Fonte: (26)

Esta estrutura é composta: pelo emissor, base, janela e retro campo na superfície traseira (BSF - back surface field). A camada ativa é composta pelo emissor e pela base cujo material é o InGaP. A janela cujo material é o AlInP, serve como uma camada passivadora para diminuir as recombinações na interface do dispositivo com o ar. O BSF tem a função de ser um campo com direção contrária ao campo da junção para melhorar a separação do par elétron-buraco a fim de diminuir a recombinação, o material desta camada é o InGaP. Nas duas extremidades estão as camadas de contato que servem para facilitar a coleta de portadores minoritários. Na interface com o ar, normalmente é colocada uma camada anti-reflexiva, para diminuir a perda de fótons por reflexão, porém, neste trabalho essa camada não foi estudada.

Depois de algumas tentativas de crescimento do AlInP devido a problemas com a dopagem ${ }^{2}$, o material ternário foi substituído pelo quaternário AlGaInP com parâmetro de rede casado com GaAs, este possui um gap grande

\footnotetext{
${ }^{2}$ Materiais com grande concentração de $\mathrm{Al}$ na sua composição apresentam grande dificuldade em atingir uma alta dopagem (28).
} 
e ajustável (27) para funcionar como janela. Por fim a estrutura que foi otimizada ficou conforme apresentado na figura 3.3.

\begin{tabular}{|l|l|}
\hline Contato & GaAs- $n$ \\
\hline Janela & AlGalnP- $n$ \\
\hline Emissor & InGaP- $n+$ \\
\hline Base & InGaP- $p$ \\
\hline BSF & AlGalnP- $p$ \\
\hline Contato & GaAs- $p$ \\
\hline
\end{tabular}

Figura 3.3: Estrutura das camadas escolhidas para simulação. A linha pontilha significa que não há material, ou seja, é o local por onde entra a luz.

\section{4}

\section{Otimização e resultados}

Com a escolha da estrutura a ser otimizada, foi dado início ao processo de otimização da célula de InGaP, cujo objetivo é maximizar a corrente produzida, para que haja o casamento com a corrente das demais células da TJSC. Para estimar a condição de balanceamento de corrente, utilizamos a equação 3-5, para calcular o número total de fótons disponível no espectro AM0. Considerando que cada fóton absorvido é convertido em um par elétronburaco e todos os portadores são coletados, a corrente elétrica máxima é a quantidade de fótons multiplicada pela carga do elétron. Podemos calcular o número total de fótons ao integrar a irradiância espectral $\mathrm{I}(\lambda)$ para AM0 de zero ao comprimento de onda limite de absorção, que coincide com o comprimento de onda de corte do Ge.

$$
\# \text { ótons }=\left(\frac{I \lambda 10^{-9}}{h c}\right)
$$

As células que compõem a TJSC estão conectadas em série, logo, as correntes são iguais. Para que haja o balanceamento desejável da corrente, os fótons devem ser absorvidos em quantidades iguais por cada junção. Dessa forma, divide-se a densidade de corrente máxima que seria gerada no dispositivo (aproximadamente $78 \mathrm{~mA} / \mathrm{cm}^{2}$ ) caso as três junções fossem conectadas em paralelo. Além disso, não se pode desconsiderar uma perda fundamental que é a reflexão na superfície. Estimando uma perda de $10 \%$ por 
reflexão, a corrente elétrica por junção é da ordem de $23 \mathrm{~mA} / \mathrm{cm}^{2}$, que foi o valor que usamos como objetivo em nossas simulações.

A fim de saber qual a espessura aproximada de InGaP poderia fornecer a corrente esperada, fizemos um cálculo baseado no balanço detalhado. $\mathrm{O}$ resultado deste cálculo está apresentado na curva de $J_{s c}$ vs espessura de InGaP apresentada na figura 3.4.

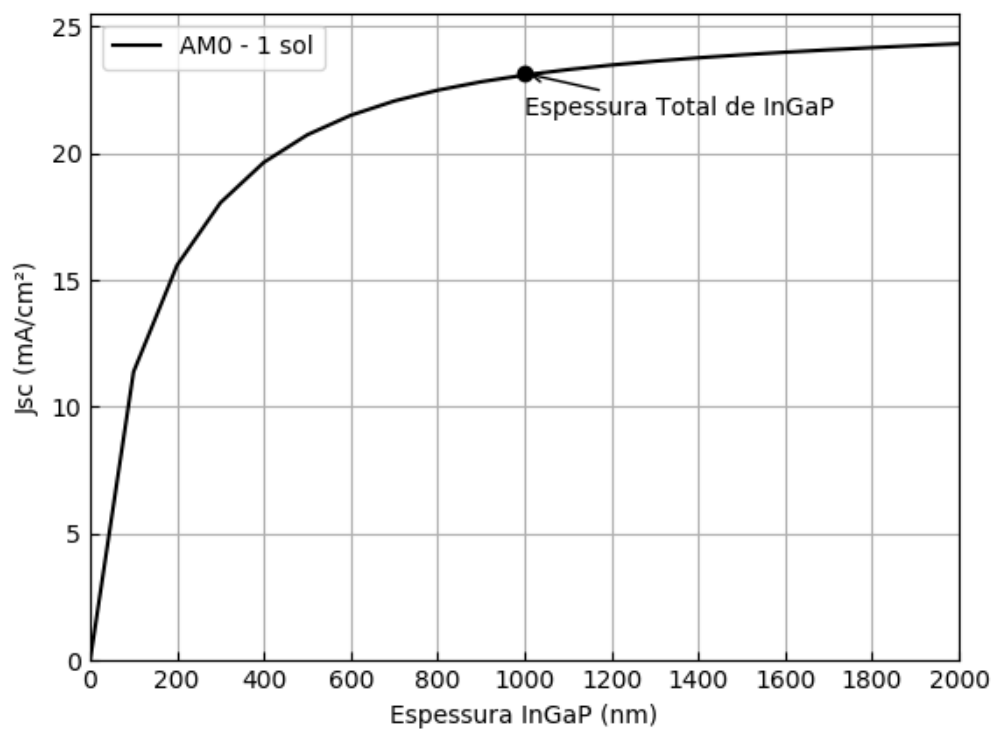

Figura 3.4: Densidade de corrente que pode ser obtida em função da espessura de InGaP utilizando o espectro AM0.

As primeiras simulações foram realizadas com os parâmetros da estrutura da figura 3.3, além de também outras estruturas da literatura, a fim de verificar o funcionamento do programa. Estas simulações foram realizadas no COMSOL. Realizamos variações na espessura de cada camada, para então selecionar os melhores resultados. Escolhida uma configuração, foram realizadas as simulações seguindo a ordem InGaP- $n$, InGaP- $p$, AlGaInP- $n$ e AlGaInP- $p$. Após cada simulação foi verificado o valor que apresentou o melhor resultado e esse valor era adicionado na estrutura. A figura 3.4 também foi utilizada para que pudéssemos escolher um valor aproximado da espessura da região ativa de acordo com a corrente que esperamos obter.

A camada $n$ é mais fina e muito dopada, já a camada $p$ é muito espessa, porém, menos dopada. Esse compromisso é devido ao comprimento de difusão do portador minoritário que, por sua vez está relacionado com a mobilidade e o tempo de vida do portador. Quando o par elétron-buraco é formado na região de depleção, devido ao campo elétrico, ele será imediatamente separado. Porém, a luz gera portadores em outras partes do material. 


\subsection{1}

\section{Emissor - InGaP-n}

Como a camada $n$ é muito dopada, isso afeta diretamente o comprimento de difusão, logo, ela precisa ser muito fina para que o percurso dos pares gerados nela seja pequeno o suficiente para chegar até o campo da junção a fim de serem separados, caso contrário o par se recombinará e a energia será perdida.

Realizamos simulações para cada camada da região ativa com valores entre 80 e $2000 \mathrm{~nm}$, pois com intervalo, menor não era possível verificar o comportamento da espessura das camadas. Os resultados apresentavam incoerências e flutuações muito grandes. A figura 3.5 apresenta os primeiros resultados referentes à camada $n$, obtidos no COMSOL.

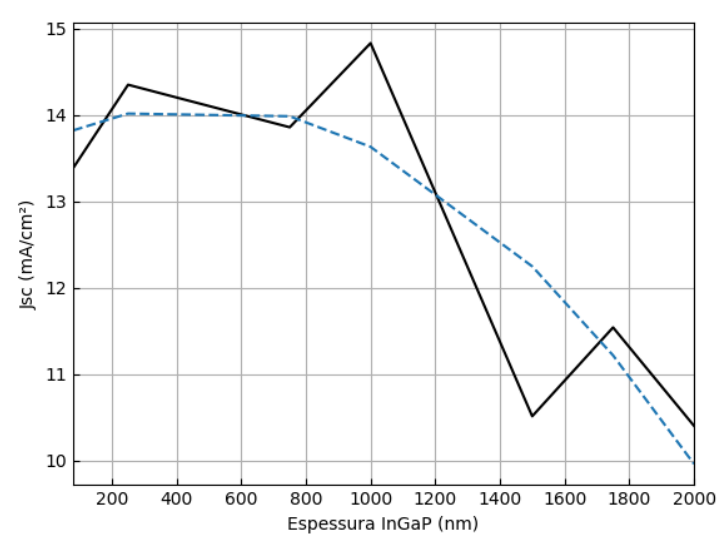

Figura 3.5: Resultados das primeiras simulações utilizando o COMSOL. Apenas fazendo um fitting é possível perceber uma tendência no comportamento da curva.

Devido a essas inconstâncias encontradas, as simulações foram transferidas para o SCAPS. É possível que esses erros sejam devido à montagem do problema, logo, o modo com que o COMSOL resolve a interação luz semicondutor causa variações na absorção. Os dados obtidos através do SCAPS possuem um comportamento mais coerente. A figura 3.6 apresenta a simulação do dispositivo para as diferentes espessuras da camada $n$.

A espessura de $80 \mathrm{~nm}$ foi a que forneceu uma maior corrente, e a dopagem desta camada continuou a mesma da estrutura base $3 \times 10^{18} \mathrm{~cm}^{-3}$. Em seguida, foram realizadas simulações variando a dopagem. A figura 3.7 apresenta os valores obtidos.

Nestas simulações podemos ver que dopagens menores fornecem uma maior corrente. De acordo com a literatura (29), existe a possibilidade de uma configuração não tradicional, onde a camada $n$ é menos dopada e mais espessa 


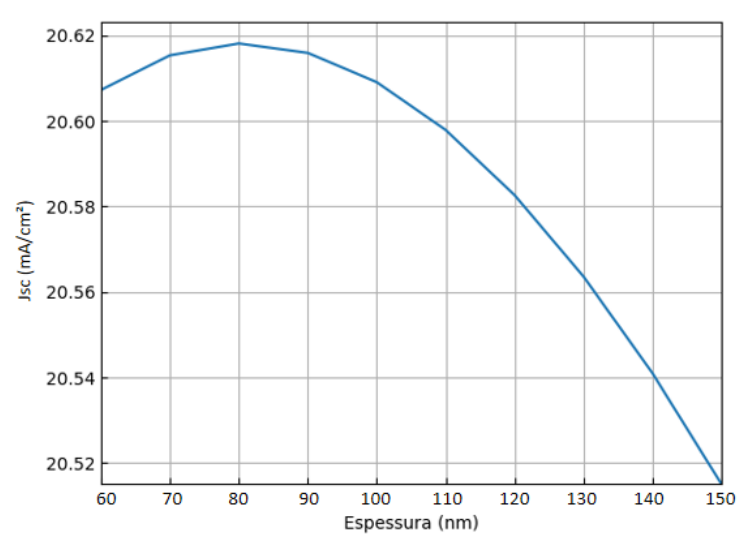

Figura 3.6: Curva de $\mathrm{J}_{s c}$ vs Espessura da camada do emissor.

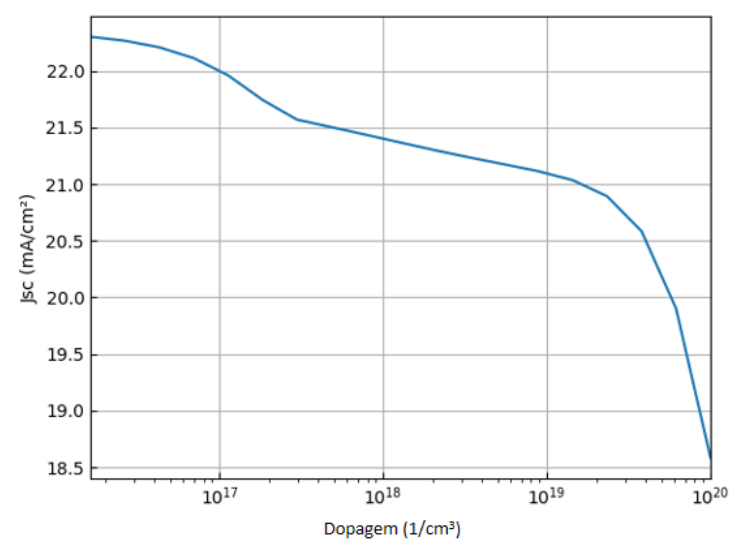

Figura 3.7: Curva $\mathrm{J}_{s c}$ vs dopagem para a camada do emissor.

que a camada $p$. Porém, como o objetivo é o casamento de corrente com as células TJSC, mantivemos a estrutura tradicional (camada $n$ mais dopada e mais fina que a camada $p$ ), e então fixamos o valor da dopagem em $3 x 10^{18} \mathrm{~cm}^{-3}$, pois a dopagem mais alta aumenta a $V_{o c}$.

\section{4 .2}

\section{Base - InGaP-p}

A camada $p$, logo, precisa ser bem menos dopada para que o portador tenha maior mobilidade. Devido a essas características a região de depleção fica mais para o lado $p$ da junção. Na camada $p$ ocorrerá a maior parte da absorção e por ser menos dopada, o comprimento de difusão é maior, característica esta que diminui a probabilidade de recombinação.

Passemos agora às simulações da camada InGaP-p. A figura 3.8 apresenta as variações de espessura e dopagem, respectivamente, para a camada $p$.

Através dessa figura podemos observar que o comportamento desta camada é como o esperado, ou seja, quanto mais espessa e com menor dopagem, maior corrente é fornecida. A dopagem escolhida foi de $2 x 10^{17} \mathrm{~cm}^{-3}$ devido a 


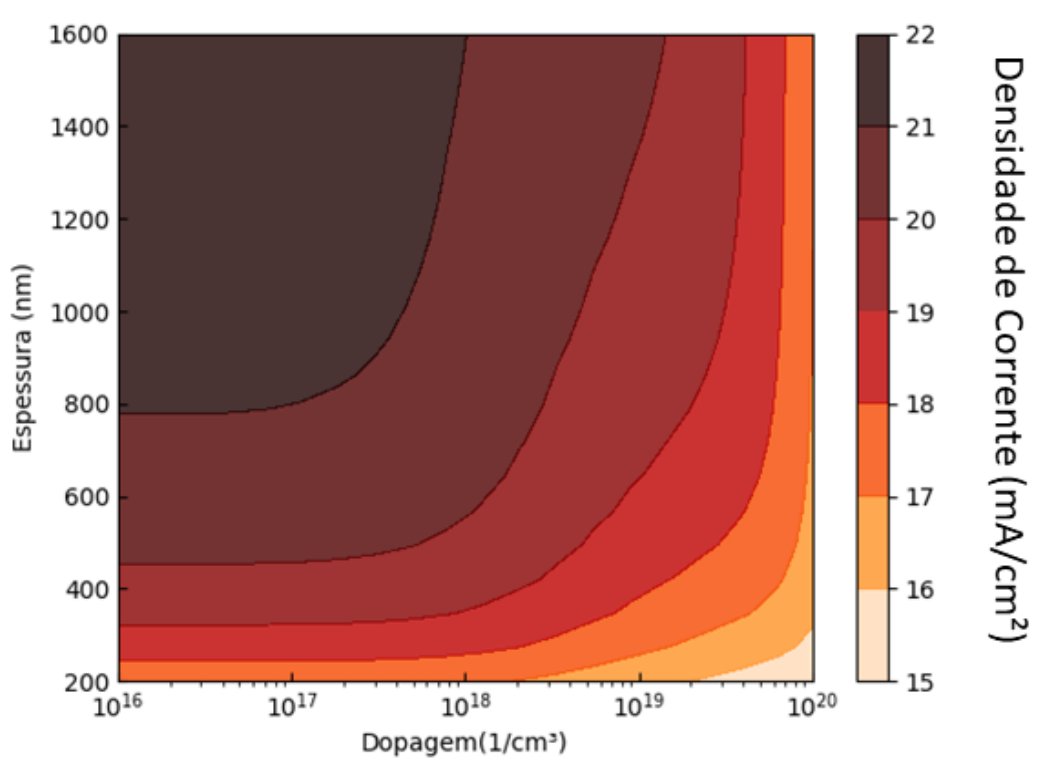

Figura 3.8: Resultado da simulação para a camada- $p$. A partir desta figura podemos obter a densidade de corrente do dispositivo em função da variação da espessura e dopagem da base.

fatores do crescimento do material que serão discutidos no próximo capítulo. O valor escolhido para a espessura foi de $1000 \mathrm{~nm}$. O critério utilizado para definir a espessura foi que o ganho de corrente por aumento de espessura não compensava o gasto de material no crescimento.

\section{4 .3}

\section{Janela - AIGalnP-n}

A camada seguinte a ser simulada foi a janela. Esta tem papel muito importante na estrutura da célula, pois sua presença faz com que a absorção seja mais longe da superfície e com isso, perdas por recombinação na superfície do dispositivo venham a ser minimizadas. Existe uma relação de compromisso para a espessura dessa camada, logo, não deve ser muito fina nem muito espessa. Quanto mais fina maior a transmissão da luz para a junção, pois não ocorreria a absorção nesta camada, porém, a junção ficaria muito próxima da superfície e o problema não será evitado. Se for muito espessa, a janela poderá absorver a luz e com isso a energia será desperdiçada. A transmissão da janela é muito importante, pois precisa ser transparente para a maioria dos comprimentos de onda do espectro solar, principalmente aqueles que serão absorvido pela junção. Com um gap acima de $60 \mathrm{meV}$, já é suficiente para que a janela seja transparente, o gap do AlGaInP utilizado nas simulações foi de 2,02 $\mathrm{eV}$ que é aproximadamente o gap do material obtido através de crescimentos anteriores. A figura 3.9 apresenta as simulações para a camada 
da janela.

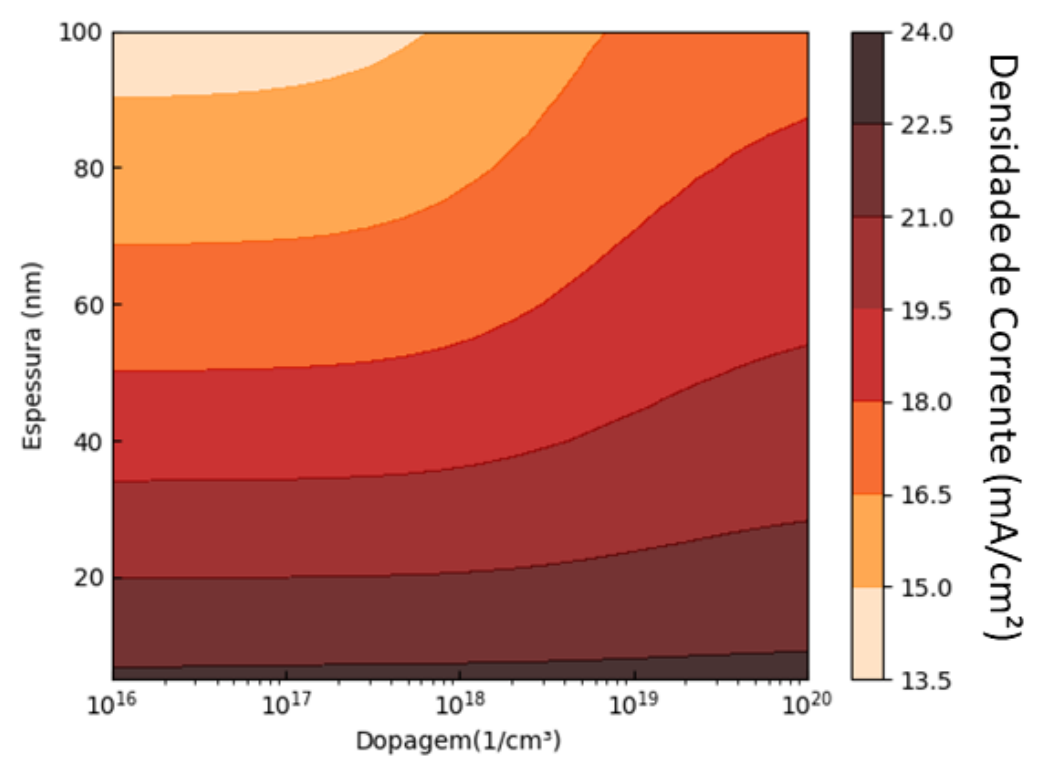

Figura 3.9: Resultado da simulação para a camada da janela. A partir desta figura podemos obter a densidade de corrente do dispositivo em função da variação da espessura e dopagem da janela.

Os valores escolhidos para espessura e dopagem foram $20 \mathrm{~nm}$ e $2 \times 10^{18} \mathrm{~cm}^{-3}$, respectivamente. De acordo com a figura 3.9 , quanto menor a espessura da camada, maior corrente é fornecida, porém ela é limitada inferiormente em função do problema da junção ficar muito próxima da superfície. Dopagens muito altas afetam diretamente a mobilidade e o software não trata a mobilidade em função da dopagem. Então esse valor de dopagem foi escolhido, levando em consideração o valor da mobilidade obtido na calibração desta camada. Visto que foi crescida uma camada de AlGaInP- $n$ com dopagem da ordem de $6 x 10^{18} \mathrm{~cm}^{-3}$ e a mobilidade foi menor.

\subsection{4}

\section{BSF - AIGalnP-p}

A espessura da camada de InGaP- $p$ escolhida foi de $1000 \mathrm{~nm}$, esta é uma camada muito espessa e a probabilidade de coleta do portador leva em consideração a profundidade que o par elétron-buraco é gerado. Os pares que são gerados a mais de um comprimento de difusão tem um percurso mais longo até sentirem a ação do campo elétrico. Essa distância favorece a recombinação nessa região $p$, pois o portador terá um caminho maior que o comprimento de difusão para percorrer. A utilização de uma camada de BSF produz um campo elétrico contrário ao da junção, favorecendo a separação do par, pois neste caso favorece a passagem de buracos para o contato inferior e afasta os 
elétrons de modo que estes tenham maior probabilidade de sentir o campo da junção e serem varridos para o contato superior. Essa dopagem faz com que a utilização do BSF aumente a diferença de potencial ao longo do dispositivo e, por conseguinte, produz um aumento na $\mathrm{V}_{o c}$. Porém, a sua espessura não tem um papel crucial nas figuras de mérito. Está apresentado na figura 3.10 as simulações do dispositivo variando a espessura e a dopagem da camada de BSF.

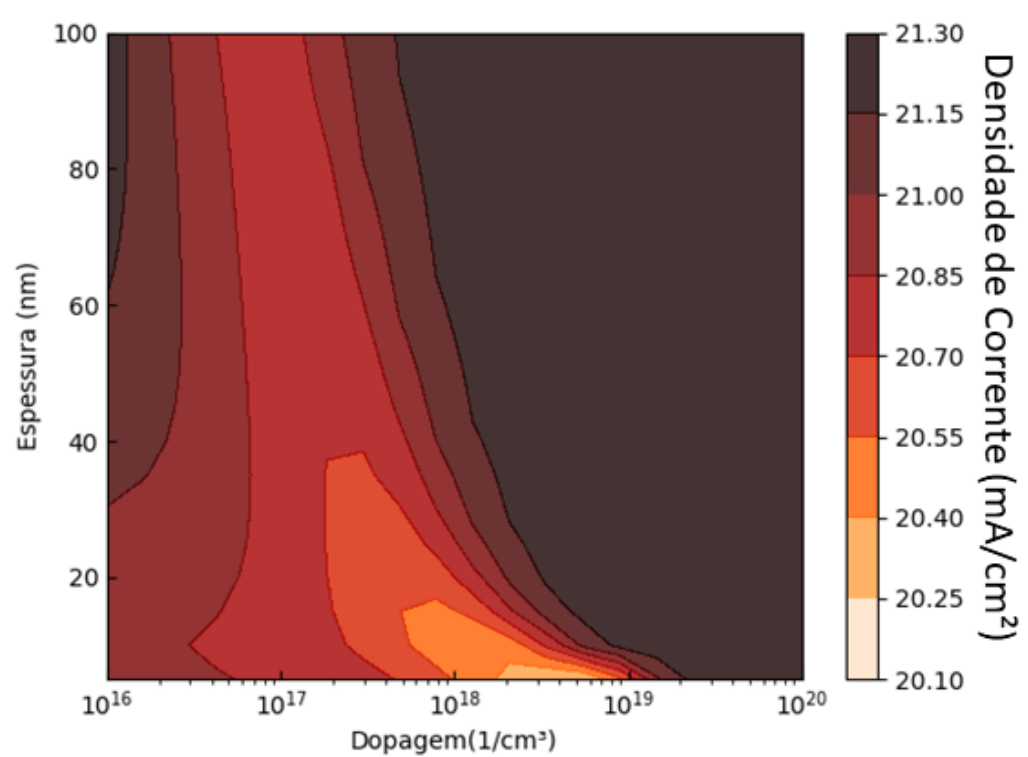

Figura 3.10: Resultado da simulação para a camada de BSF. A partir desta figura podemos obter a densidade de corrente do dispositivo em função da variação da espessura e dopagem do BSF.

Os valores de espessura e dopagem escolhidos para o BSF foram $30 \mathrm{~nm}$ e $3 x 10^{18} \mathrm{~cm}^{-3}$. Uma dopagem mais alta seria melhor, mas o critério utilizado foi levando em consideração limitações no crescimento em relação à dopagem de materiais com Al na composição.

As camadas de contato não necessitam de otimização. Sua característica é a alta dopagem para aumentar a mobilidade do portador majoritário favorecendo a formação de um contato ôhmico com o metal. Os valores de dopagem das camadas de contato estão diretamente ligados com a limitação da fabricação. Os valores de espessura foram obtidos de outros trabalhos de células solares produzidos em nosso laboratório. Para o caso da TJSC a camada de contato- $p$ será substituída por um diodo túnel.

De acordo com o resultado obtido das simulações de cada uma das camadas, foi possível escolher uma estrutura que deve fornecer uma corrente casada com as correntes das demais células. A estrutura escolhida está apresentada 
na figura 3.11. A curva $I V$ está apresentada na figura $3.12 \mathrm{com}$ suas figuras de mérito.

\begin{tabular}{|l|ll|}
\hline GaAs- $n$ & $100[\mathrm{~nm}]$ & $5 \mathrm{e} 18\left[\mathrm{~cm}^{-3}\right]$ \\
\hline AlGalnP- $n$ & $20[\mathrm{~nm}]$ & $2 \mathrm{e} 18\left[\mathrm{~cm}^{-3}\right]$ \\
\hline InGaP- $n+$ & $80[\mathrm{~nm}]$ & $3 \mathrm{e} 18\left[\mathrm{~cm}^{-3}\right]$ \\
\hline InGaP- $p$ & $1000[\mathrm{~nm}]$ & $2 \mathrm{e} 17\left[\mathrm{~cm}^{-3}\right]$ \\
\hline AlGalnP- $p$ & $30[\mathrm{~nm}]$ & $3 \mathrm{e} 18\left[\mathrm{~cm}^{-3}\right]$ \\
\hline GaAs- $p$ & $300[\mathrm{~nm}]$ & $7 \mathrm{e} 18\left[\mathrm{~cm}^{-3}\right]$ \\
\hline
\end{tabular}

Figura 3.11: Representação da estrutura final definida através dos resultados das simulações. Nesta representação estão colocados também os valores que foram utilizados para as camadas de contato.

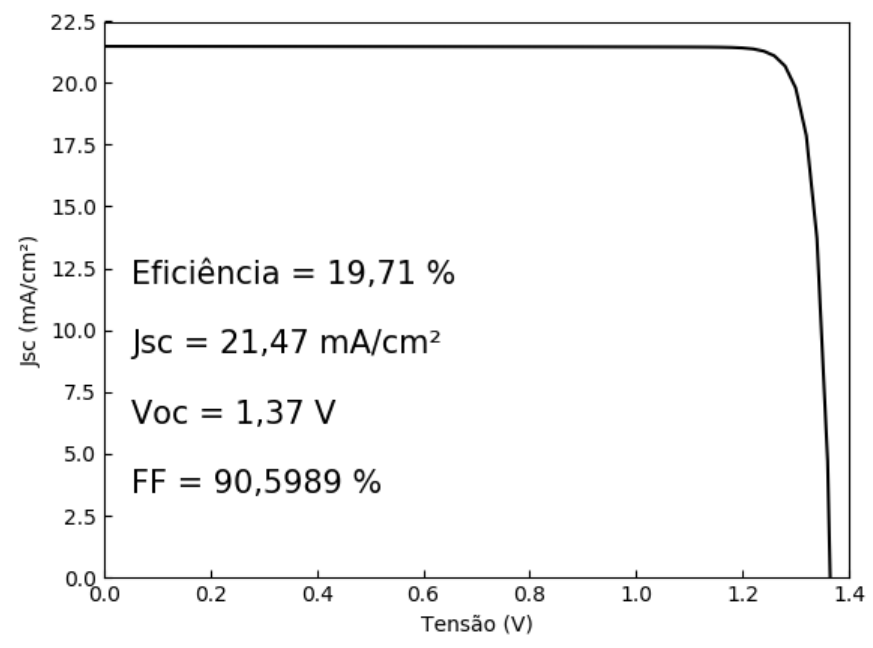

Figura 3.12: Curva $J V$ obtida na simulação da estrutura final juntamente com as figuras de mérito obtidas.

Os resultados das simulações são coerentes com o esperado. Fatores como mobilidade dos portadores, velocidade térmica, tempo de vida e etc. precisariam de um tratamento melhor, por exemplo aceitar que fosse adicionada uma curva de mobilidade por dopagem, então seria possível obter uma resposta mais precisa ao fazer variações de um determinado parâmetro. 


\section{4}

\section{Fabricação dos dispositivos}

Diversos materiais podem ser usados como fonte para a produção de dispositivos semicondutores. A tabela 4.1 é um recorte da tabela periódica com alguns desses materiais. Os materiais utilizados nesse trabalho fazem parte da chamada família III-V que como o próprio nome diz são materiais que estão nas colunas III e V.

\begin{tabular}{ccccc}
\hline II & III & IV & V & VI \\
\hline & $\mathrm{B}$ & $\mathrm{C}$ & $\mathrm{N}$ & $\mathrm{O}$ \\
& $\mathrm{Al}$ & $\mathrm{Si}$ & $\mathrm{P}$ & $\mathrm{S}$ \\
$\mathrm{Zn}$ & $\mathrm{Ga}$ & $\mathrm{Ge}$ & $\mathrm{As}$ & $\mathrm{Se}$ \\
$\mathrm{Cd}$ & $\mathrm{In}$ & $\mathrm{Sn}$ & $\mathrm{Sb}$ & $\mathrm{Te}$ \\
\hline
\end{tabular}

Tabela 4.1: Recorte da tabela periódica mostrando com materiais semicondutores.

Neste capítulo abordaremos o processo de fabricação do dispositivo, cuja definição de estrutura foi apresentada no capítulo anterior. O processo de fabricação pode ser dividido em duas etapas: o crescimento das camadas e o processamento. Essas etapas serão apresentadas e em sequência os resultados obtidos através das caracterizações feitas.

\section{1}

\section{Crescimento}

\subsection{1}

\section{Metalorganics Vapor Phase Epitaxy}

A técnica utilizada foi de crescimento Epitaxial usando MetalOrgânicos em Fase Vapor (MOVPE do inglês MetalOrganics Vapor Phase Epitaxy). A palavra epitaxia tem origem no grego, epi = "sobre" e taxis = "arranjo", ou seja, a técnica consiste no "arranjar" as moléculas que formam o semicondutor "sobre" o substrato aquecido. Os semicondutores produzidos por MOVPE tem ótima qualidade cristalina, pois os átomos se organizam de acordo com a orientação do substrato monocristalino. Essa técnica é amplamente utilizada 
na indústria, pois é possível produzir diversos tipos de dispositivos, como: diodo emissor de luz(LED), lasers, fotodetectores, etc.

A figura 4.1 é um esquema simplificado da estrutura de um sistema MOVPE. Nela podemos observar da esquerda para a direita: $\mathrm{H}_{2}$ gás de arraste e o $\mathrm{N}_{2}$ gás utilizado por segurança para abertura da câmara do reator, pois $\mathrm{H}_{2}$ é potencialmente explosivo em contato com o ar. Temos as fontes de hidretos e metalorgânicos, os hidretos são metais da família $\mathrm{V}$ que tem sua forma $\left(\mathrm{VH}_{3}\right)$ : fosfina $\mathrm{PH}_{3}$ e a arsina $\mathrm{AsH}_{3}$ e nesta parte da figura temos também a silana $\mathrm{SiH}_{4}$ que servirá como dopante tipo- $n$. Na parte correspondente aos metalorgânicos temos os metais da coluna III que são ligados a três radicais metil tendo a forma $\left(\left(\mathrm{CH}_{3}\right)_{3} \mathrm{III}\right)$ e são eles: trimetilíndio $\left(\left(\mathrm{CH}_{3}\right)_{3} \mathrm{In}\right)$, trimetilgálio $\left(\left(\mathrm{CH}_{3}\right)_{3} \mathrm{Ga}\right)$ e trimetilalumínio $\left(\left(\mathrm{CH}_{3}\right)_{3} \mathrm{Al}\right)$. E como fonte de dopante tipo- $p$ temos também o dimetilzinco $\left(\left(\mathrm{CH}_{3}\right)_{2} \mathrm{Zn}\right)$. Seguindo a linha dos fluxos temos à direita a câmara do reator, onde acontece a reação química. Conectado a câmara temos o scrubber que é um sistema de filtragem dos gases tóxicos. O scrubber converte os gases resultantes da reação em líquidos ou sólidos para o devido descarte.

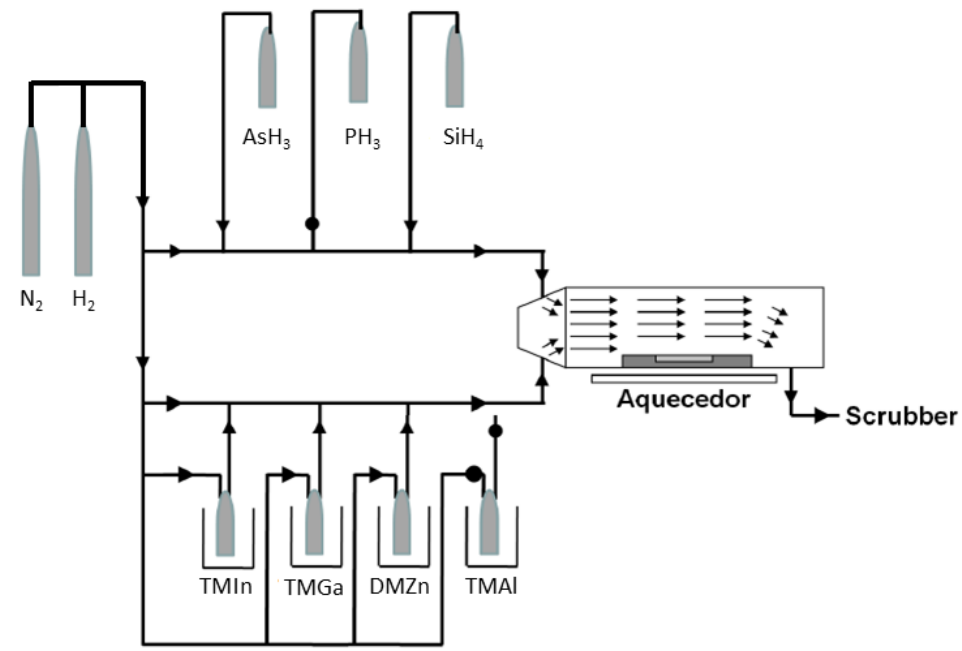

Figura 4.1: Esquema simplificado do funcionamento do reator de MOVPE. Onde estão representados o gás de arraste e as fontes de metalorgânicos. Adaptado de (30).

O ambiente para que a reação química possa acontecer precisa ser favorável. A temperatura e a pressão possuem um controle muito preciso, pois qualquer variação pode acarretar problemas para a cristalinidade da estrutura crescida. Para inserir os precursores na câmara, o gás de arraste borbulha dentro da fonte gerando um vapor do precursor. Este vapor é direcionado para dentro da câmara onde acontecerá a reação. Como visto na figura 4.1 os grupos não se misturam até que estejam dentro da câmara. 
A reação acontece, pois devido a alta temperatura, ocorre uma decomposição dos compostos na fase de vapor gerando espécies reativas. Estas espécies difundem para o substrato aquecido onde adsorvem e buscam um sítio que minimize sua energia. A última parte da reação é a formação do produto III-V que fica adsorvido no substrato e o agrupamento destas moléculas forma o filme.

O grupo metil liberado pelos metalorgânicos reage com o hidrogênio liberado pelos hidretos formando $\mathrm{CH}_{4}$ que é transportado pelo gás de arraste para o sistema de filtragem. A seguir é apresentada a reação química que acontece dentro da câmara juntamente com a figura que ilustra o processo.

$$
\left(\mathrm{CH}_{3}\right)_{3} \mathrm{III}+\mathrm{VH}_{3} \longrightarrow \mathrm{IIIV}+3 \mathrm{CH}_{4}
$$

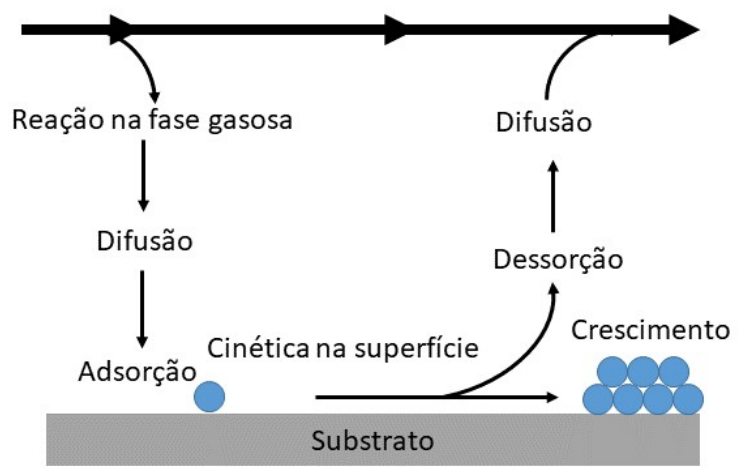

Figura 4.2: Representação das etapas do processo químico que ocorre na câmara do reator.

As amostras foram crescidas em substrato de GaAs semi-isolante, com direção cristalina (100). O GaAs foi escolhido, pois este tem parâmetro de rede semelhante ao Ge que é a base da célula tripla. Controlando o fluxo dos gases podemos controlar a composição e a dopagem dos semicondutores crescidos. A temperatura de crescimento é um fator muito importante, pois está estritamente relacionada com a cristalinidade do material crescido. Caso a temperatura seja muito baixa, a mobilidade dos átomos para encontrar seu sítio na superfície do substrato será menor, isto deve acarretar prejuízos na qualidade cristalina. A temperatura de crescimento estipulada foi de $675^{\circ} \mathrm{C}$, pois com este valor é possível crescer um InGaP com boa qualidade cristalina(31).

Os materiais III-V possuem a estrutura zinc-blende em sua célula unitária com a proporção 1:1, ou seja, um átomo do grupo III para um átomo do grupo V, isso quer dizer que cada grupo terá participação de 50\%. Então utilizaremos a notação de $\operatorname{In}_{x} \mathrm{Ga}_{1-x} \mathrm{P}$ omitindo os $50 \%$ referentes ao fósforo. 


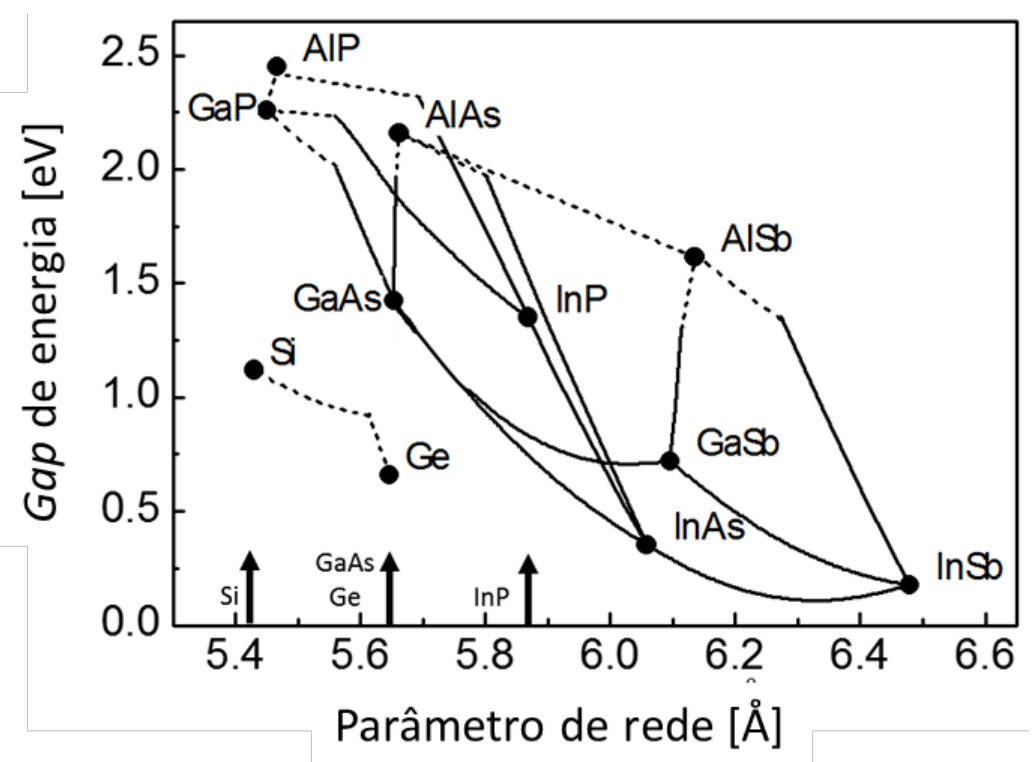

Figura 4.3: Gráfico clássico de optoeletrônica que relaciona o gap dos semicondutores com o respectivo parâmetro de rede.

Na figura 4.3 está apresentado um gráfico clássico em optoeletrônica, onde são mostradas as combinações dos materiais III-V e suas composições com seus parâmetros de rede e gaps associados.

O parâmetro de rede do substrato de GaAs é de 5,64 A. O casamento do parâmetro de rede acontece quando o filme crescido possui o mesmo parâmetro de rede do substrato, isso é feito para evitar tensões na rede cristalina.

A composição de InGaP, cujo parâmetro de rede é casado com GaAs, é de $48 \%$ de In, $52 \%$ de gálio ou como na notação $\operatorname{In}_{0,48} \mathrm{Ga}_{0,52} \mathrm{P}$. Por apenas esta composição ser casada com o GaAs normalmente os percentuais são omitidos. A composição de InGaP pode ser inferida utilizando o parâmetro de rede obtido através da técnica de difração de raio-x.

A formação do InGaP pode ser entendida como a reação entre dois binários, o InP e o GaP. No caso do quaternário de interesse, sua formação pode ser entendida como a reação entre três binários, ou de forma mais simples, a reação entre dois ternários, neste caso o InGaP e o AlInP que formam então o AlGaInP. Para encontrar a composição do quaternário é preciso utilizar a técnica de raio-x em conjunto com a técnica de fotoluminescência, pois este possui diversas composições que podem ser casadas com o GaAs.

A espessura é outro fator importante, esta é controlada pela taxa de deposição que por sua vez depende da temperatura, pressão e do fluxo total do grupo III. Antes do crescimento do dispositivo final, foram calibradas e crescidas separadamente cada camada que compõe o filme epitaxial. As calibrações e caracterizações deste processo serão discutidos nos próximos 
tópicos.

\subsection{2}

\section{Difração de raios- $X$}

Na calibração das camadas epitaxiais, uma das técnicas mais fundamentais é a difração de raios-X (DRx). A partir dela obtemos informações sobre a qualidade cristalina, espessura e parâmetro de rede do filme crescido. Com o parâmetro de rede é possível calcular a composição dos materiais crescidos. No caso dos quaternários, é utilizado o parâmetro de rede em conjunto com o pico obtido através da fotoluminescência para encontrar a composição.

A equação fundamental da análise de difração de raios-x é a lei de Bragg apresentada pela equação 4-1. Essa equação descreve a relação entre a distância interplanar das camadas atômicas $(d)$ com o ângulo de incidência $(\theta)$ de uma radiação de comprimento de onda $(\lambda)$. A distância $d$ fornece diretamente $o$ parâmetro de rede do material.

$$
n \lambda=2 d \operatorname{sen} \theta
$$

Foi utilizado o esquema de duplo cristal no experimento de difração de raio-x, pois este fornece uma melhor resolução. A figura 4.4 é a representação esquemática do equipamento. Como mostrado na figura, o primeiro cristal é utilizado para remover a dispersão dos comprimentos de onda, ou seja, agindo como colimador e monocromador (32) permitindo um cálculo mais preciso do parâmetro de rede da amostra.

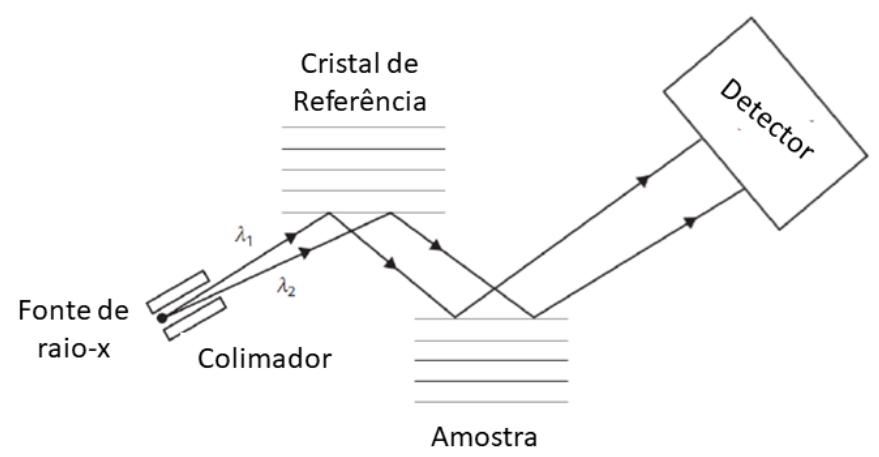

Figura 4.4: Esquema da montagem experimental utilizada na medida de difração de raio-x. Fonte: (30)

Quando a condição de Bragg é obedecida o feixe colimado incide sobre a amostra, gerando um pico de intensidade em função do ângulo. Na situação de casamento do parâmetro de rede os picos provenientes do filme crescido e do substrato estão superpostos formando um único pico largo. No caso dos 
parâmetros de rede não estarem casados (camada crescida e substrato com parâmetros de rede diferentes) ambos difratam em ângulos distintos.

O descasamento entre os picos é descrito pela equação 4-2 (32), a partir da qual é possível calcular o parâmetro de rede da camada crescida. Na figura 4.5 temos a representação do padrão de difração.

$$
\frac{\Delta d}{d}=-\cot \theta \cdot \Delta \theta
$$

onde $\Delta d$ é o descasamento e $\Delta \theta$ é a variação angular.

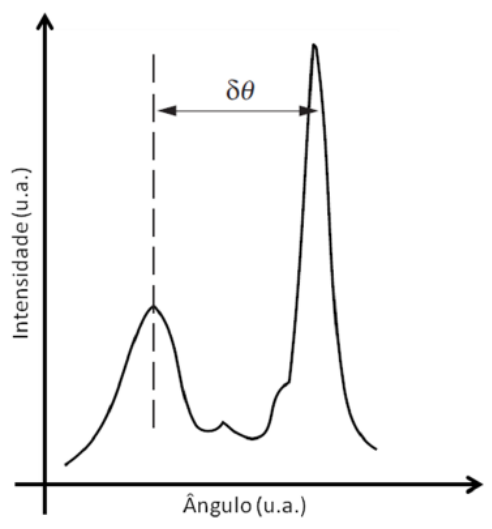

Figura 4.5: Representação de um difratograma genérico, onde o pico de mais alta intensidade representa o substrato e o pico de mais baixa intensidade representa a camada crescida.

A utilização do $\mathrm{Rx}$ é fundamental no processo de calibração, pois a partir das informações de composição e parâmetro de rede fornecidas podemos orientar os crescimentos subsequentes, a fim de casar o parâmetro de rede.

\subsection{3}

\section{Fotoluminescência}

A fotoluminescência (PL) é uma técnica de caracterização ótica capaz de fornecer a diferença entre o estado de energia mais alta na banda de valência e o estado de menor energia disponível na banda de condução. Com a PL podemos obter: a energia do gap do semicondutor, composição da liga, nível de energia de impurezas e defeitos, etc.

A PL é uma técnica não destrutiva e ocorre basicamente em duas etapas: um feixe de fótons com energia maior que o gap, incide sobre o semicondutor provocando uma transição do elétron da banda de valência para a banda de condução; o elétron termaliza e emite um fóton com a mesma energia do seu gap. 
A figura 4.6 apresenta um esquema da montagem experimental utilizada para medir a PL das amostras.

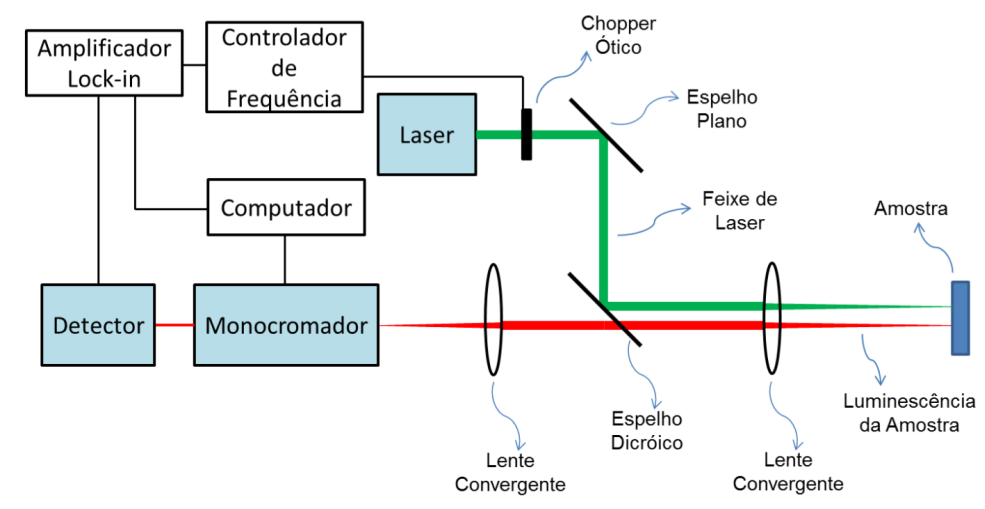

Figura 4.6: Representação esquemática da montagem utilizada na medição de fotoluminescência. Fonte: (33)

O laser utilizado foi um VERDI com comprimento de onda $532 \mathrm{~nm}(2,3$ eV). O feixe emitido sai do laser e passa por um chopper que possui uma frequência selecionada, esse feixe é focalizado sobre a amostra através de lentes, espelhos e filtros. A detecção do sinal da PL emitido pelo semicondutor é direcionado para um monocromador por filtros e lentes. O monocromador possui uma grade de difração que varre um espectro de comprimentos de ondas permitindo apenas que o sinal referente à luminescência do material chegue ao detector.

Esse sinal é então enviado para um detector que converte o sinal luminoso em elétrico. Neste experimento foi utilizada uma fotomultiplicadora ERMA II que possui faixa de operação entre $320 \mathrm{~nm}$ e $900 \mathrm{~nm}$. O sinal elétrico do detector é enviado para o lock-in e para um computador onde será salvo. A resolução do experimento varia de acordo com os parâmetros do monocromador, que são: abertura das fendas de entrada e saída, e passo do motor que controla a angulação da rede de difração. Na figura 4.6 o laser, em verde, é focalizado sobre a amostra através do conjunto ótico de espelhos e lentes. Em vermelho é a emissão da amostra, que é focada na entrada do monocromador também por espelhos, lentes e filtros de densidade neutra.

A caracterização elétrica das camadas crescidas foi realizada utilizando duas técnicas: a medida de efeito Hall e o perfil eletroquímico de capacitânciatensão (CV do inglês Capacitance-Voltage). O efeito Hall foi utilizado para as camadas: janela, emissor e base. O CV foi utilizado para a camada de BSF. 


\subsection{4}

\section{Efeito Hall}

O efeito Hall é conhecido desde 1879 quando foi descoberto por Edwin H. Hall (34). Basicamente esse efeito consiste em fornecer uma corrente elétrica ao material e medir a diferença de potencial perpendicularmente, ambos sobre o plano da amostra, com a inserção de um campo magnético perpendicular ao plano da amostra. A preparação das amostras é realizada de forma prática utilizando o método desenvolvido por Van der Pauw (35). Este método consiste na aplicação dos contatos metálicos para a coleta dos portadores no contorno da amostra. A figura 4.7 representa a preparação dos contatos e sua configuração.

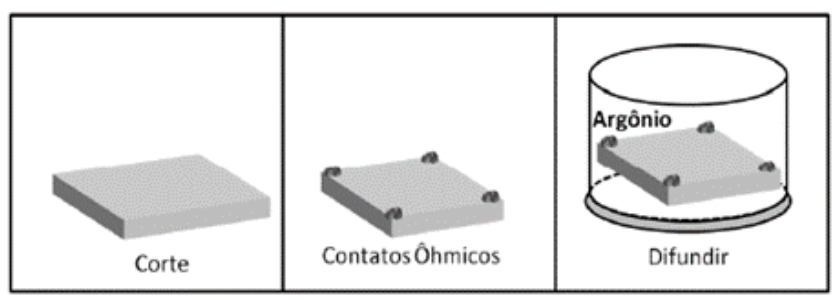

Figura 4.7: Preparação e configuração dos contatos seguindo o método de Van der Pauw. Fonte: (30)

A presença da corrente promove o deslocamento dos portadores e quando sob ação do campo magnético este sofrem a ação da força chamada força de Lorentz. Esse força produz um desvio no caminho dos portadores sendo acumulados na extremidade perpendicular a sua rota normal. Um desbalanceamento das cargas ocorre quando há o acumulo das cargas nas extremidades do material. Quando a força de Lorentz entra em equilíbrio com a força gerada pelo campo elétrico aparece uma diferença de potencial que é conhecida como tensão Hall. A tensão Hall é dada pela equação 4-3:

$$
V_{H}=\frac{-I B}{n q d}
$$

onde I é a corrente e B é o campo magnético aplicados sobre a amostra, $\mathbf{n}$ é a densidade portadores, $\mathbf{q}$ é a carga do elétron, $\mathbf{d}$ a largura do filme.

Na figura 4.8 está representada a montagem experimental e a configuração dos contatos.

A medida de efeito Hall nos fornece a definição do tipo dos portadores indicando se a amostra é dopada $n$ ou $p$ de acordo com o sinal da tensão Hall. Podemos obter a densidade superficial de portadores e a densidade volumétrica 


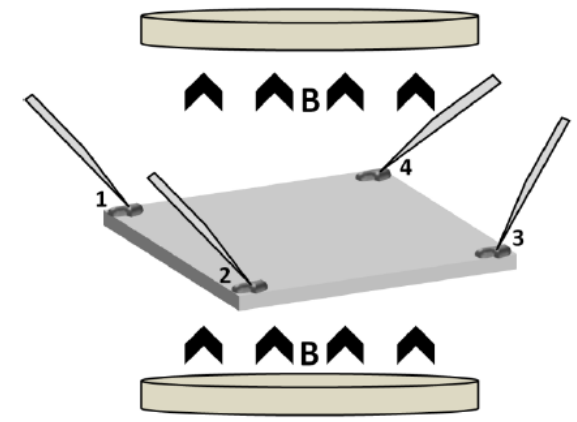

Figura 4.8: Representação da montagem experimental utilizada para a medição de efeito Hall. Fonte: (30).

que pode ser obtida utilizando a informação da espessura da camada crescida. Essa espessura pode ser obtida através da técnica de difração de raios-x.

Como representado na figura 4.8 a amostra é preparada na forma de Van der Pauw colocando o metal que fará o contato que neste caso é o índio-estanho para amostras tipo- $n$ e índio-zinco para as amostras tipo- $p$. A colocação dos contatos deve seguir duas condições importantes (a partir do método): a área do contato, deve ser pelo menos uma ordem de grandeza menor que a área da amostra; e que elas devem estar colocadas de forma que cada ponto seja o vértice de um quadrado.

Após a colocação dos contatos é feito um tratamento térmico com até $400^{\circ} \mathrm{C}$ dentro de um forno com atmosfera inerte (neste caso, a mistura era de 95\% Ar e 5\% H) para que a liga difunda um pouco no semicondutor e seja produzido um contato ôhmico.

O equipamento utilizado para fazer a medida é um sistema Hall da BIO RAD dedicado a medidas de transporte elétrico. Este sistema possui quatro ponteiras que devem ser colocadas em ordem sobre os contatos e possui também um imã de 0,3 tesla utilizado para aplicar o campo magnético.

\subsection{5}

\section{Perfil eletroquímico de capacitância-tensão}

Com uma abordagem e um método diferente, a técnica de perfil eletroquímico de capacitância-tensão, ou capacitância-voltagem (CV), é capaz de medir a dopagem de semicondutores assim como o efeito Hall. Porém o efeito Hall mede a dopagem através das cargas móveis, já o CV mede a concentração dos portadores a partir das cargas fixas em função de uma profundidade corroída. Devido à essa corrosão CV é uma técnica destrutiva. A figura 4.9 representa como é a montagem da célula eletroquímica do CV.

Essa montagem é colocada no equipamento BIO-RAD CV profiling utilizado para realizar o experimento. O perfil eletroquímico é feito de maneira 


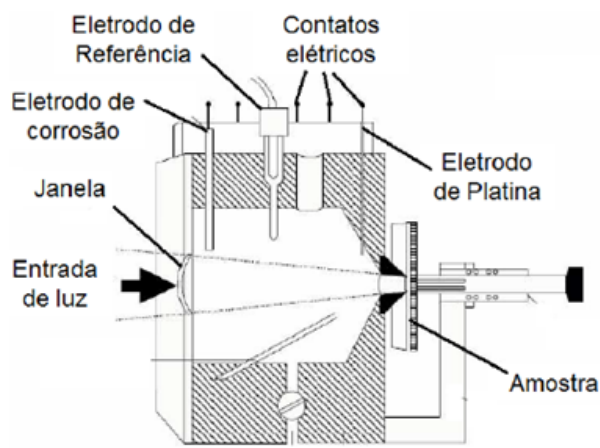

Figura 4.9: Célula eletroquímica utilizada para medidas de CV. Fonte: (33).

alternada entre a medida da concentração de portadores e a corrosão do material. A medida é realizada a partir de uma barreira Schottky formada no contato entre o semicondutor e o eletrólito. Esta barreira Schottky cria uma região de depleção que é desprezível no interior do eletrólito, ou seja, ela fica completamente dentro do semicondutor. Na região de depleção existe uma capacitância que é dependente da concentração do portador e da tensão reversa aplicada. Essa relação é dada pela equação 4-4:

$$
C=A\left[\frac{e N_{d, a} \epsilon}{2\left(V_{b i}-V_{a}\right)}\right]_{1 / 2}
$$

onde $\mathbf{A}$ é a área de contato entre o semicondutor e o eletrólito, $\epsilon$ é a constante dielétrica do semicondutor, $\mathbf{V}_{b i}$ o potencial de contato (built in) da junção, $\mathbf{N}_{d, a}$ a densidade de impurezas doadoras (ou aceitadoras) ionizadas e $\mathbf{V}_{a}$ uma tensão reversa aplicada sobre a junção.

A célula eletroquímica funciona em parte como um reservatório do eletrólito. A amostra é pressionada contra o anel de selamento, a área desse anel define a área de contato entre o eletrólito e o semicondutor. A região de depleção é criada devido à aplicação de uma tensão reversa $V_{a}$ entre o semicondutor e o eletro de platina. O eletrodo restante controla as corrente de corrosão, o sentido de aplicação de tensão de corrosão depende do tipo do semicondutor.

\section{2 \\ Processamento}

Posteriormente a calibração das camadas, é feito então o crescimento do dispositivo final, ou seja, crescendo todas camadas empilhadas. Porém para que a estrutura crescida funcione como um dispositivo é preciso passar pela etapa de processamento. Nesta etapa utilizamos técnicas de fotolitografia, 
corrosão química e metalização a fim de transformar a amostra crescida em um dispositivo funcional. Conseguimos fazer o processamento de uma amostra no LabSem, porém devido a problemas com nossa metalizadora, o processamento das demais amostras foi realizado no laboratório de novos materiais semicondutores (LNMS) da USP.

As etapas do processamento são: fotolitografia dos contatos superiores, metalização dos contato superior, lift-off, fotolitografia da mesa, corrosão das mesas, metalização do contato inferior, lift-off, corrosão camada de contato superior (Retirada da camada de contato GaAs). No apêndice B está o formulário utilizado para guiar o processamento.

A fotolitografia é o processo de gravação de um padrão sobre a amostra. Esse padrão é transferido, pois é utilizada uma resina fotossensível chamada de fotorresiste. A transferência do padrão (proveniente da máscara) segue alguns passos: colocação do fotorresiste sobre a amostra, cura, alinhamento do padrão, sensibilização do fotorresiste, revelação. Dois tipos de processos são possíveis: positivo e negativo. A figura 4.10 é uma representação simplificada dos dois tipos de processo de fotolitografia.

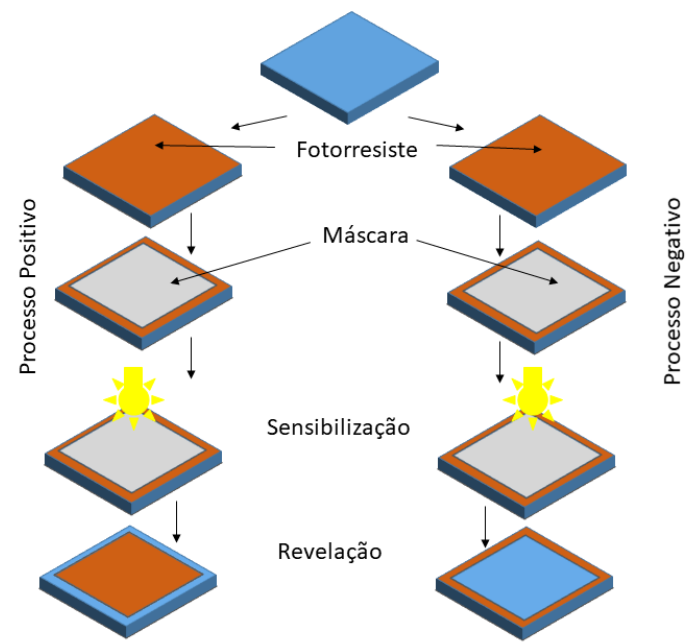

Figura 4.10: Resumo dos procedimentos de fotolitografia para os processos positivo e negativo.

No processo positivo a região de fotorresiste que foi exposta (à luz ultravioleta) sairá no momento da revelação. Diferente do processo negativo que a área exposta permanece após a revelação. Isso porque o fotorresiste negativo passa por um processo de cura após a exposição. Nesta etapa a região sensibilizada endurece de modo que permanece após a revelação. Vale ressaltar que o fotorresiste que possui a característica de reversão de imagem, quando utilizado para o processo negativo, depois de passar pela segunda etapa de 
cura, passa também por uma etapa de super exposição onde toda a amostra é exposta a luz. Esta etapa é a que promove a mudança nas suas propriedades.

No processamento deste trabalho foram utilizadas duas máscaras complementares. A primeira possui os padrões dos dedos ou fingers e a segunda possui os padrões das mesas. Estas máscaras precisam ser complementares, pois é feito o alinhamento entre elas para que a gravação do padrão seja feita de modo que a área do dispositivo seja corroída de forma correta e os contatos estejam dentro da região da mesa. Na figura 4.11 estão apresentadas as imagens das máscaras utilizadas.

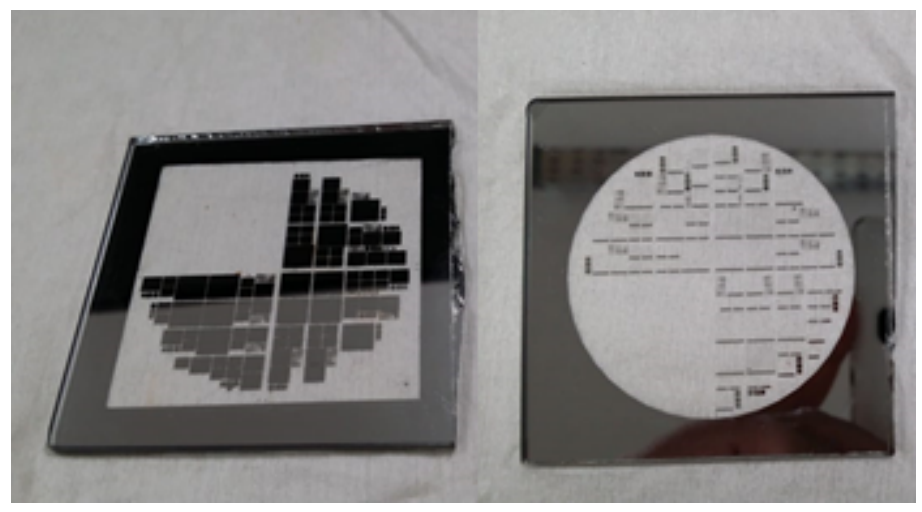

Figura 4.11: Fotografia das máscaras utilizadas no processamento.

Antes da gravação dos padrões na amostra final, foi realizada a calibração dos parâmetros de fotolitografia. Essa calibração visa encontrar os parâmetros de: deposição, sensibilização e revelação para cada fotorresiste em cada processo. Na etapa de deposição calibramos o tempo de rotação no spinner que afeta diretamente a espessura do fotorresiste e o tempo e temperatura de cura. $\mathrm{Na}$ etapa de sensibilização ajustamos o tempo de exposição do fotorresiste, pois é necessário que o filme de fotorresiste seja sensibilizado uniformemente. Na etapa de revelação calibramos o tempo de revelação e a concentração da solução reveladora, a fim de que obtenhamos um boa resolução do padrão transferido.

Foram utilizados três fotorresistes: AR-P3740, AR-N4400-10, AZ5214E. Os dois primeiros foram utilizados no processamento feito no LabSem, o ARP3740 foi utilizado no processo positivo e o AR-N4400-10 foi utilizado no processo negativo. O terceiro fotorresiste foi utilizado no processamento feito no LNMS e este serve para os dois processos, pois este resiste possui uma característica de reversão das suas propriedades. As tabelas a seguir são um resumo da etapa de fotolitografia.

A tabela 4.2 mostra os fotorresistes utilizados com as respectivas máscaras e o processo realizado. A primeira coluna serve como identificação, pois as próximas tabelas fazem referência aos processos e fotorresistes. 


\begin{tabular}{|c|c|c|c|}
\hline & Processo & Fotorresiste & Máscara \\
\hline 1 & Positivo & AR-P3740 & Mesa \\
\hline 2 & Positivo & AZ5214E & Mesa \\
\hline 3 & Negativo & AR-N4400-10 & fingers \\
\hline 4 & Negativo & AZ5214E & fingers \\
\hline
\end{tabular}

Tabela 4.2: Nesta tabela estão apresentados os processos com os fotorresistes e máscaras correspondentes.

A tabela 4.3 apresenta os dados da calibração da colocação do filme de fotorresiste sobre a amostra.

\begin{tabular}{|c|c|c|c|}
\hline & Espessura & Velocidade & Tempo \\
\hline 1 & $1,4 \mu \mathrm{m}$ & $4000 \mathrm{RPM}$ & $60 \mathrm{~s}$ \\
\hline 2 & $1,6 \mu \mathrm{m}$ & $4000 \mathrm{RPM}$ & $60 \mathrm{~s}$ \\
\hline 3 & $5,9 \mu \mathrm{m}$ & $4000 \mathrm{RPM}$ & $50 \mathrm{~s}$ \\
\hline 4 & $1,6 \mu \mathrm{m}$ & $4000 \mathrm{RPM}$ & $60 \mathrm{~s}$ \\
\hline
\end{tabular}

Tabela 4.3: Resultado da calibração da fotolitografia parte 1.

Na tabela 4.4 estão apresentados os dados de cura, exposição e revelação do fotorresiste.

\begin{tabular}{|c|c|c|c|c|c|}
\hline & Cura & Exposição & Crosslink & Sol. Rev. & Revelação \\
\hline 1 & $100{ }^{\circ} \mathrm{C} / 1 \mathrm{~min}$ & $360 \mathrm{~s}$ & - & $4 \% \mathrm{KOH}: \mathrm{H}_{2} \mathrm{O}$ & $60 \mathrm{~s}$ \\
\hline 2 & $100^{\circ} \mathrm{C} / 1 \mathrm{~min}$ & $7 \mathrm{~s}$ & - & AZ400 & $20 \mathrm{~s}$ \\
\hline 3 & $90^{\circ} \mathrm{C} / 4 \mathrm{~min}$ & $240 \mathrm{~s}$ & $100{ }^{\circ} \mathrm{C} / 3 \mathrm{~min}$ & $4 \% \mathrm{KOH}: \mathrm{H}_{2} \mathrm{O}$ & $150 \mathrm{~s}$ \\
\hline 4 & $90^{\circ} \mathrm{C} / 4 \mathrm{~min}$ & $3,2 \mathrm{~s} / 13,4 \mathrm{~s}$ & $100^{\circ} \mathrm{C} / 3 \mathrm{~min}$ & $\mathrm{AZ} 400$ & $20 \mathrm{~s}$ \\
\hline
\end{tabular}

Tabela 4.4: Resultado da calibração da fotolitografia parte 2 .

Vale ressaltar que, na tabela 4.4, nas linhas 1 e 3 da coluna solução reveladora, está apresentada a solução utilizada, porém, esta possui concentração diferente dependendo do processo. No processo positivo a concentração é de 1:4 4\% KOH: $\mathrm{H}_{2} \mathrm{O}$ e no processo negativo a concentração é de 1:2 4\% KOH: $\mathrm{H}_{2} \mathrm{O}$. A linha 4 na coluna exposição possui dois tempos de exposição, pois como foi dito este resiste pode funcionar para os dois processos, e no caso do processo negativo é preciso que haja uma super exposição sem a utilização de máscaras, para que então haja a reversão nas propriedades do material. Os tempos de exposição diferem devido a potência da lâmpada utilizada em cada fotoalinhadora.

Posterior à etapa de fotolitografia, fizemos a corrosão das mesas. Nesta etapa de corrosão foram utilizadas soluções que corroem seletivamente. Foram 
realizados testes de corrosão a fim de contabilizar o tempo de corrosão para evitar underetching, que seria uma corrosão que invade a área da mesa por baixo do fotorresiste.

As soluções utilizadas na corrosão da camada de contato foram: $\mathrm{H}_{2} \mathrm{SO}_{4}: \mathrm{H}_{2} \mathrm{O}_{2}: \mathrm{H}_{2} \mathrm{O}$ na concentração 1:8:40 e uma solução de Ác. Cítrico: $\mathrm{H}_{2} \mathrm{O}_{2}$ na concentração 3:1 estas soluções atacam apenas materiais que possuem o arsênio. A solução $\mathrm{H}_{2} \mathrm{SO}_{4}: \mathrm{H}_{2} \mathrm{O}_{2}: \mathrm{H}_{2} \mathrm{O}$ foi utilizada para corroer a camada de contato no momento da corrosão das mesas e com esta solução obtivemos uma taxa de corrosão de aproximadamente $1 \mu \mathrm{m} / \mathrm{min}$. Para corroer a região entre os fingers utilizamos a solução de ácido cítrico com uma taxa de aproximadamente $200 \mathrm{~nm} / \mathrm{min}$. Para as camadas de InGaP e AlGaInP utilizamos uma solução de $\mathrm{HCl}: \mathrm{H}_{2} \mathrm{O}$ que ataca apenas materiais com fósforo. Esta solução foi utilizada na concentração 3:1 e possui uma taxa de $800 \mathrm{~nm} / \mathrm{min}$. Nós escolhemos a corrosão seletiva, pois as amostras foram crescidas sobre substrato semi-isolante, e isso anula o risco de corroer uma profundidade maior do que o esperado e ultrapassar a camada de contato.

A última etapa do processamento das amostras é a metalização dos contatos. Nesta etapa foi feita a calibração para deposição dos metais. Nesta calibração foi realizado: ajuste do tooling factor e a definição da corrente de deposição. O tooling factor é um fator geométrico que está relacionado com a posição do cristal de quartzo. Neste processo foram realizadas algumas deposições e a verificação das espessuras foram realizadas utilizando um perfilômetro. A equação 4-5 é utilizada para o ajuste do tooling factor.

$$
T F_{f}=T F_{i} \frac{\text { Espessura }}{\text { Espessura }_{\text {esperada }}}
$$

Onde $\mathrm{TF}_{f}, \mathrm{TF}_{i}$ são respectivamente o tooling factor final e o inicial.

Antes de cada metalização foi utilizada uma solução de $\mathrm{HCl}: \mathrm{H}_{2} \mathrm{O}$ para remoção de óxido. No caso das amostras finais foi utilizada uma solução de HF com o mesmo objetivo.

A tabela 4.5 apresenta os metais utilizados para os respectivos contatos juntamente com as espessuras depositadas.

\begin{tabular}{|c|c|c|}
\hline Tipo contato & Metais & Espessuras $($ nm $)$ \\
\hline$n$ & $\mathrm{Ni} / \mathrm{Ge} / \mathrm{Au}$ & $30 / 50 / 250$ \\
\hline$p$ & $\mathrm{Ti} / \mathrm{Pt} / \mathrm{Au}$ & $20 / 50 / 200$ \\
\hline$p$ & $\mathrm{Ti} / \mathrm{Pt} / \mathrm{Au}$ & $20 / 100 / 200$ \\
\hline
\end{tabular}

Tabela 4.5: Contatos metálicos produzidos. 
A tabela 4.5 possui dois contatos $p$, onde o primeiro com $50 \mathrm{~nm}$ de platina foi feito no LabSem e o segundo no LNMS. A fim de verificar a qualidade dos contatos produzidos utilizamos a técnica de TLM que será abordada no próximo tópico.

\subsection{1}

TLM

O método de linha de transmissão (TLM - Transmission Line Measurement) pode fornecer muitas informações sobre os contatos produzidos, por exemplo: resistência metal-semicondutor, resistência de folha, resistividade do contato, etc.

Para fazer a medida de TLM é preciso utilizar um conjunto de estruturas de contatos com dimensões e distância conhecidas. A figura 4.12 mostra figuras de TLM utilizadas na medida. Para cada par de pads (AB, BC, CD, DE e EF) fazemos uma curva $I V$, onde calculando o inverso da inclinação $(1 / \alpha)$ de cada curva obtemos a resistência entre os pads. Plotando estas resistências entre os pads em função da distância entre eles, podemos obter a resistência de contato entre o metal e o semicondutor, através do coeficiente linear da curva. A figura 4.13 representa a curva de TLM.

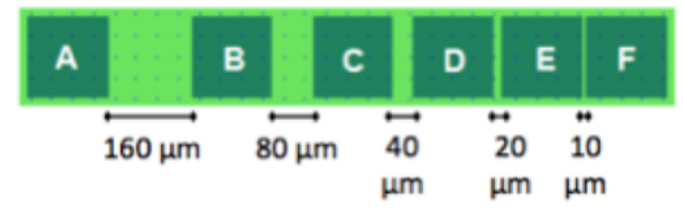

Figura 4.12: Padrão de pads utilizados para produzir os contatos para a medida de TLM. Este padrão está presente na máscara de fingers. Fonte: (36).

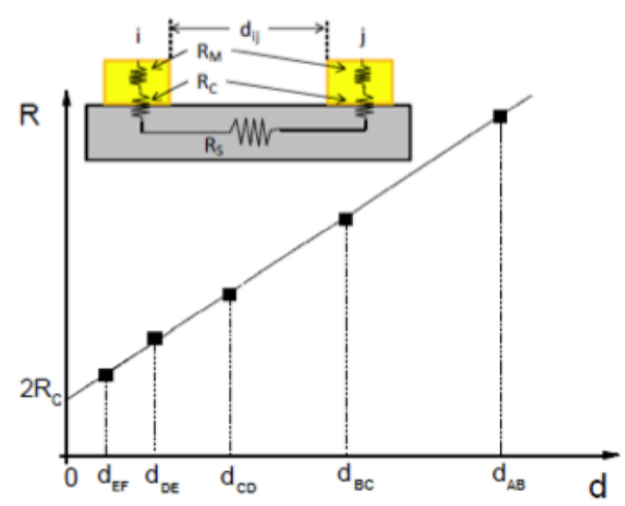

Figura 4.13: Curva de resistência vs distância obtida a partir das curvas $I V$ feitas. A incisão é uma representação da medida de TLM. Fonte: (36). 
A equação 4-6 é utilizada para fazer o fitting da curva da figura 4.13;

$$
R(d)=2 R_{m}+2 R_{c}+R_{s} d
$$

onde $\mathrm{R}_{m}$ é a resistência do metal, $\mathrm{R}_{c}$ é a resistência do contato entre o metal e o semicondutor, e $\mathrm{R}_{s}$ é a resistência do semicondutor. $\mathrm{R}_{m}$ por ser muito menor que as demais pode ser desprezada, e então a equação 4-6 pode ser reescrita na forma:

$$
R_{T}=2 R_{C}+\left(\frac{R_{S H}}{W}\right) d R(d)=2 R_{c}+R_{s}=2 R_{c}+\frac{\rho_{s}}{l} d_{i j}
$$

onde $\rho_{s}$ é a resistividade de folha do semicondutor, $l$ é o tamanho do contato e $d_{i j}$ é a distância entre dois contatos. Através da curva de TLM podemos obter a $\mathrm{R}_{c}$ através do coeficiente linear, ou seja, quando a reta toca no eixo y e através do coeficiente angular podemos obter $\rho_{s}$.

\section{3}

\section{Resultados}

\subsection{1}

\section{Crescimento}

Nesta seção serão apresentados os resultados obtidos da calibração do crescimento das camadas, onde serão apresentados os dados da difração de raios-x $(\mathrm{Rx})$, fotoluminescência (PL), efeito Hall (Hall) e perfil eletroquímico de capacitância-voltagem (CV) para as amostras fabricadas.

No processo de calibração do crescimento, são produzidas duas ou mais amostras para cada camada a ser calibrada, pois o ajuste dos parâmetros do crescimento é feito de forma empírica. De acordo com resultados obtidos, por exemplo, sobre o descasamento do parâmetro de rede de uma certa camada, podemos escolher novos parâmetros de crescimento para os crescimentos subsequentes de forma a obter camadas casadas com o substrato de GaAs. Para facilitar a calibração são mantidos constantes os fluxos de $\mathrm{PH}_{3}$ e TMIn, e os parâmetros de temperatura e pressão. A primeira caracterização feita após o crescimento de uma amostra é o DRx. Como foi dito, a partir desta medida obtemos muitas informações sobre o que foi crescido.

Começamos crescendo uma amostra de InGaP sem dopante utilizando como base os parâmetros de um crescimento de InGaP já realizado no LabSem. O resultado foi uma amostra com um pequeno descasamento para a direita do pico do substrato, isso indica que um maior percentual de Gálio foi incorporado. Está apresentado na figura 4.14 o difratograma obtido. 


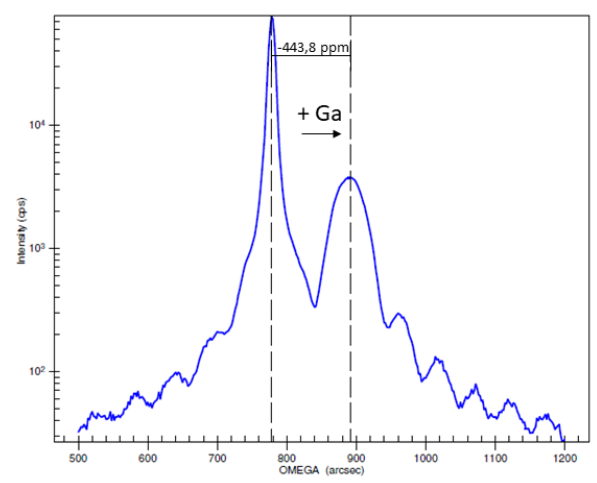

Figura 4.14: Espectro de difração de raio-x de InGaP não dopado. A seta indica a influência do gálio sobre o descasamento do material ternário.

Fizemos um segundo crescimento diminuindo o fluxo de Ga de 4,05 (utilizado no crescimento anterior) para 3,96 sccm. Como resultado da segunda amostra, obtivemos um descasamento para esquerda do pico do substrato, o que indica que um maior percentual de In foi incorporado. Foi feito um gráfico descasamento vs razão Ga sobre grupo III que está apresentado na figura 4.15.

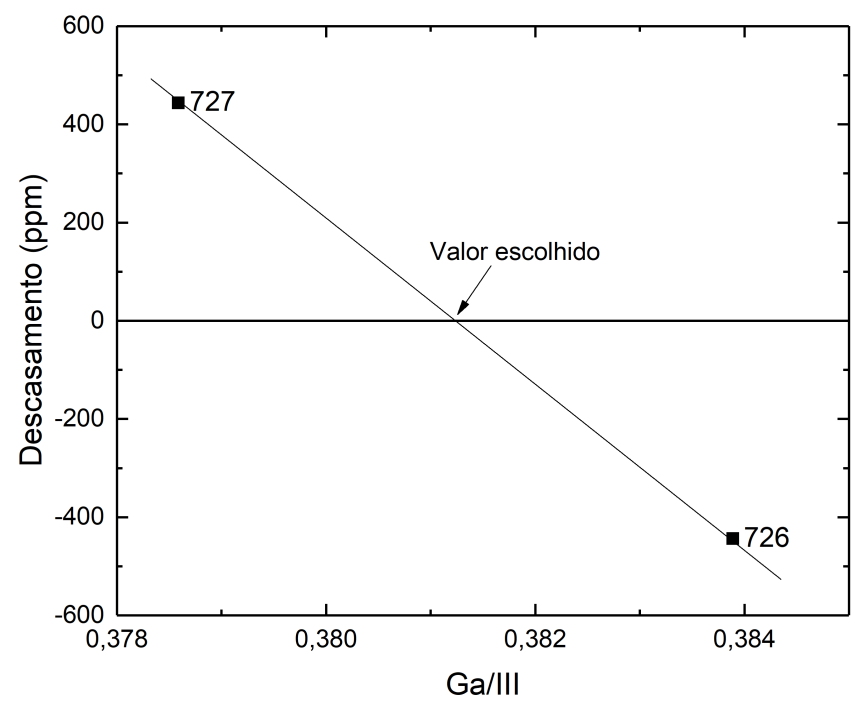

Figura 4.15: Descasamento vs razão gálio sobre grupo III para amostras crescidas de InGaP não dopado.

Neste gráfico traçamos uma reta que conecta as duas amostras. O ponto dessa reta que representa o zero de descasamento é o novo valor de fluxo de Ga utilizado para crescer a próxima amostra a fim de casar o parâmetro de rede.

A partir da calibração da amostra não dopada iniciamos a calibração das amostras dopadas. Primeiro foi a camada do emissor que possui dopagem tipo- 
n. Lembrando que a composição casada do $\operatorname{InGaP}$ é $\operatorname{In}_{0,48} \mathrm{Ga}_{0,52} \mathrm{P}$, podemos considerar que uma amostra com diferença de $1 \%$ na composição está dentro do erro do cálculo e por isso pode ser considerada aproximadamente casada. A composição da primeira amostra dopada foi de 48,6\% de In, apenas $0,6 \%$ maior que a composição casada. Nesta amostra fizemos a medida de efeito Hall para obter a concentração de dopantes. A dopagem resultou em $1,4 x 10^{18} \mathrm{~cm}^{-3}$ que está abaixo do esperado que seria da ordem de $3 \times 10^{18} \mathrm{~cm}^{-3}$ de acordo com a simulação. Uma segunda amostra foi crescida aumentando o fluxo do dopante em dez vezes. Porém, a dopagem obtida foi da ordem de $5 \times 10^{18} \mathrm{~cm}^{-3}$. Para encontrar o fluxo de dopante que forneça a concentração desejada, fizemos o processo semelhante ao anterior, no qual plotamos concentração do dopante vs fluxo de dopante sobre grupo III. Este gráfico está apresentado na figura 4.16.

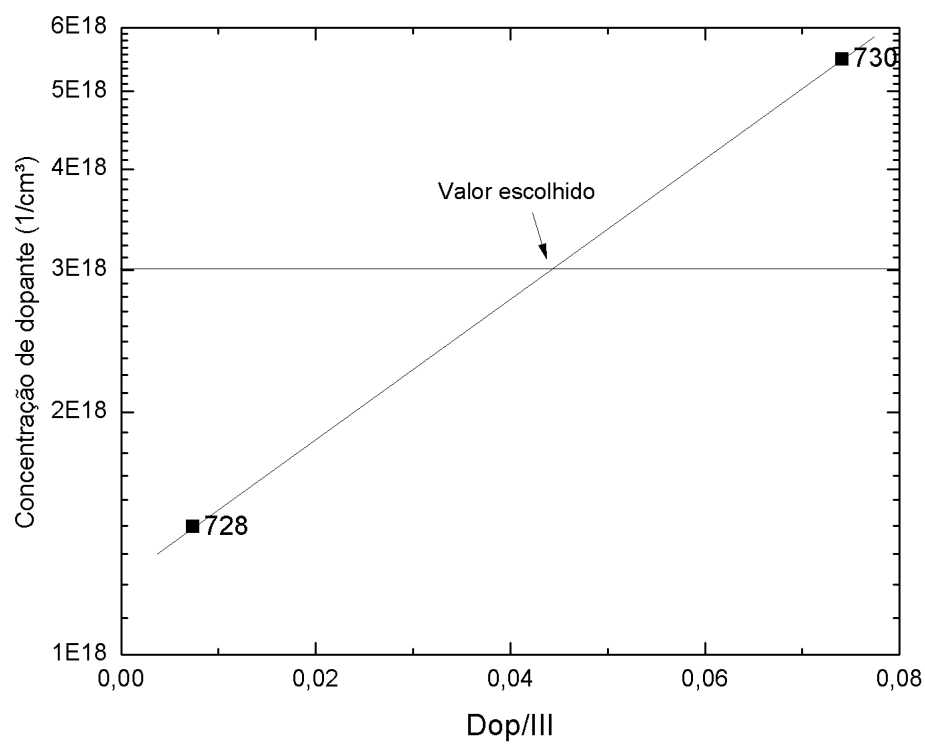

Figura 4.16: Concentração de dopantes vs razão do fluxo de dopantes sobre o grupo III para calibração da camada de InGaP tipo- $n$.

Calibrada a camada do emissor, prosseguimos com a calibração da base. Esta camada possui dopagem tipo- $p$ e teve seu crescimento baseado na camada de InGaP não dopado, o fluxo do dopante foi baseado em um crescimento antigo. A figura 4.17 é o gráfico com o descasamento das amostras em relação ao fluxo de dopante. A dopagem objetivo é $2 x 10^{17} \mathrm{~cm}^{-3}$ de acordo com o que foi obtido pela simulação.

Como podemos observar através da figura 4.17 estas amostras apresentaram um descasamento em torno do zero para um fluxo de TMGa fixo obtido na calibração da amostra não dopada. Logo, nesta etapa o objetivo foi encon- 


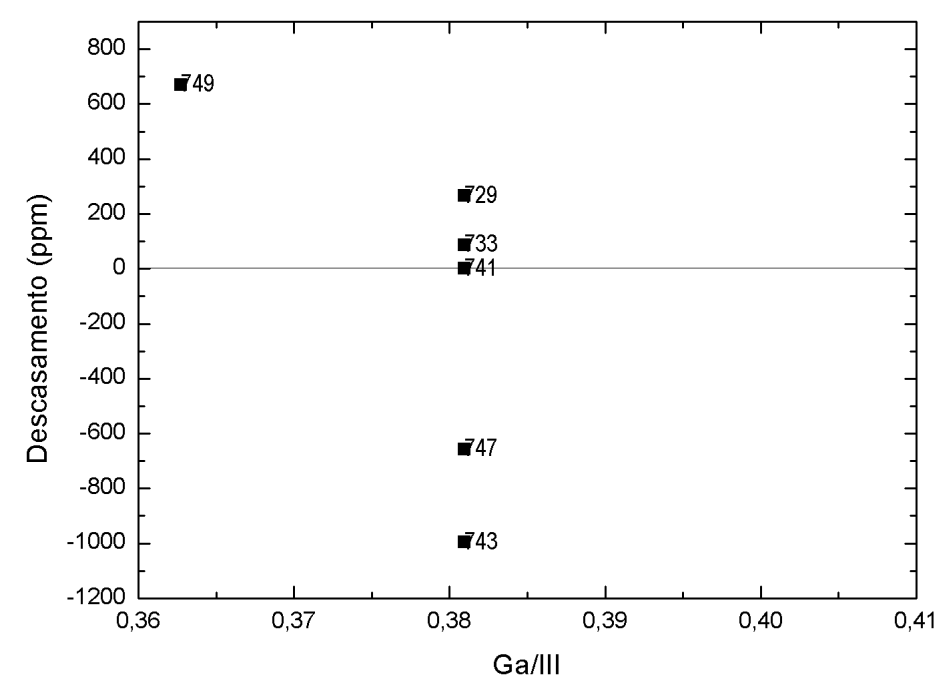

Figura 4.17: Descasamento vs razão do fluxo de gálio sobre o grupo III para calibração do InGaP tipo- $p$.

trar o fluxo de dopante para atingir a dopagem esperada. Na figura 4.18 está apresentado o gráfico de dopagem vs fluxo de dopante sobre o grupo III.

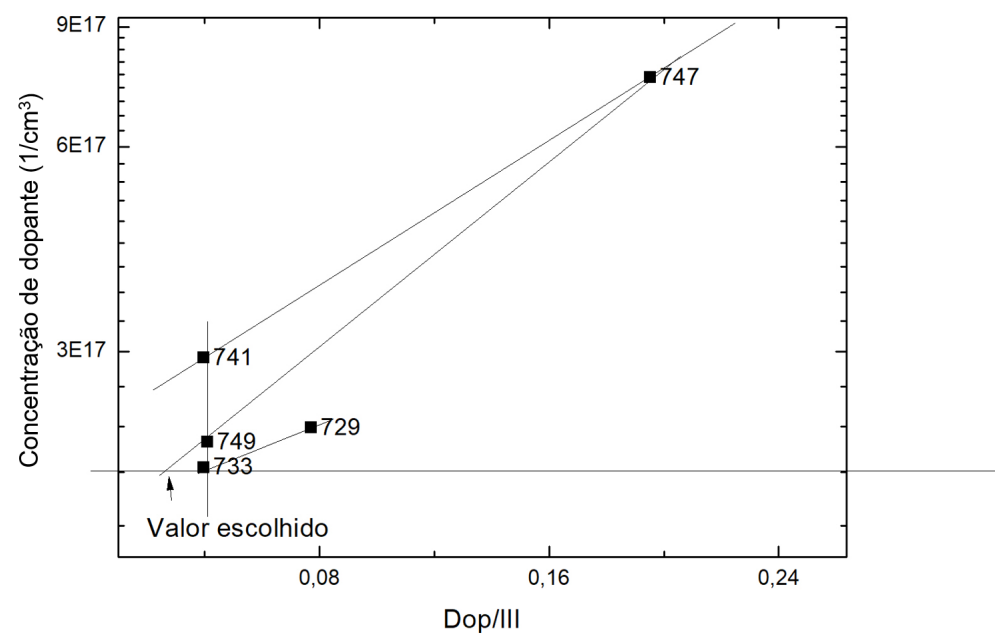

Figura 4.18: Dopagem vs razão do fluxo de dopantes sobre o grupo III para calibração do InGaP tipo- $p$.

Estas amostras de InGaP-p foram calibradas e seus valores de fluxos foram utilizados para o crescimento da amostra finais. No entanto, a primeira amostra com a estrutura completa apresentou alguns defeitos na superfície como pode ser observado na figura 4.19.

Para resolver este problema nós produzimos mais duas amostras com a razão V/III mais baixa que a utilizada na calibração. Isto foi feito, pois a razão 
V/III alta pode gerar esse tipo de defeito na superfície, de acordo com o artigo (28). Após o crescimento destas duas amostras, os defeitos na superfície das amostras finais subsequentes diminuíram, porém, não desapareceram.

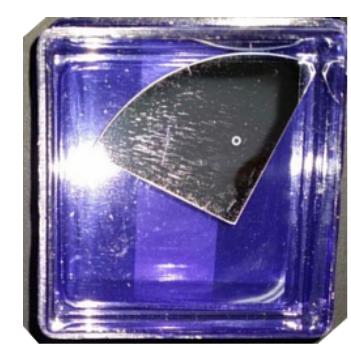

Figura 4.19: Fotografia da amostra final que apresentou microestruturas na superfície.

Foram realizadas medidas de PL das amostras de $\operatorname{InGaP} n$ e $p$. Estas medidas não influenciam diretamente na calibração das amostras, pois como visto na figura 4.3 a composição das ligas ternárias pode ser facilmente obtida com o resultado do parâmetro de rede. No entanto, o resultado da PL é importante, pois a largura a meia altura (FWHM - Full Width Half Maximum) do pico da PL é uma indicação da qualidade cristalina do material.

Na figura 4.20 estão apresentados os espectros de PL das camadas de calibração de InGaP tipo $n$.
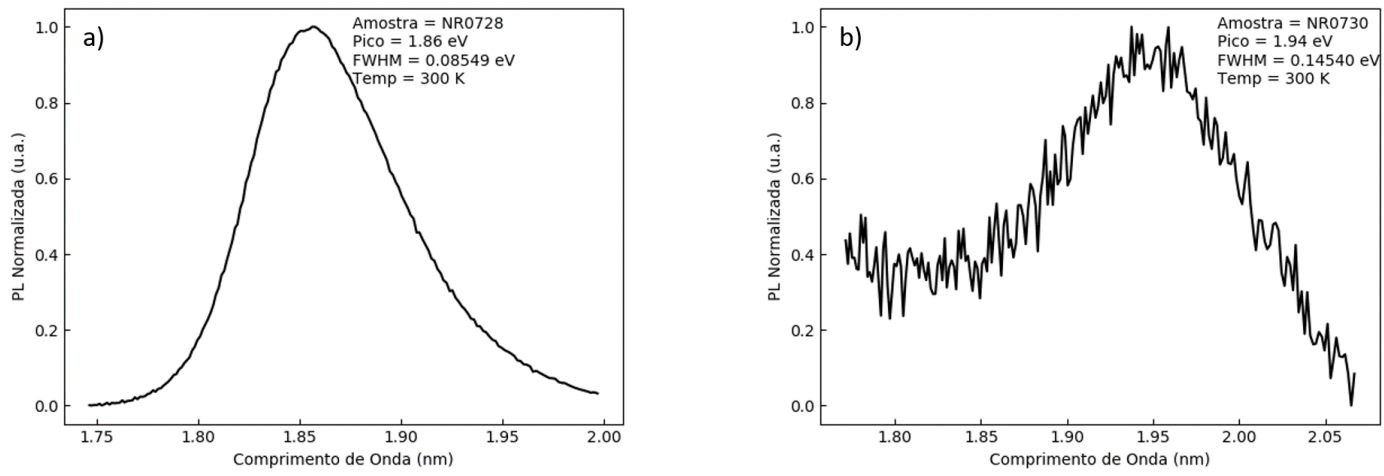

Figura 4.20: Espectros de PL obtidos para amostras de InGaP-n. Em (a) temos um fluxo de dopante dez vezes menor que em (b).

A diferença dos espectros é devido ao fluxo de dopantes. Na figura 4.20(b) o fluxo de dopante foi maior que a camada da figura 4.20(a), logo, a camada da figura 4.20(b) possui uma dopagem maior do que a camada referente a figura 4.20(a). Neste caso podemos observar a influência da incorporação de dopante na estrutura do filme crescido. Comparando as duas curvas, podemos perceber que a qualidade cristalina piorou com o aumento na incorporação de dopantes. A FWHM aumentou em aproximadamente $60 \mathrm{meV}$. No entanto, 
para o crescimento na estrutura final o fluxo de dopante foi ajustado e a tendência da qualidade cristalina é melhorar, pois a quantidade de dopante será menor. Também é interessante observar que o gap apresentado pela figura 4.20 (b) é $100 \mathrm{meV}$ maior que o da figura 4.20(a). Esse efeito pode ser devido ao aumento de dez vezes do fluxo de dopante entre os crescimentos causando uma variação na cinética da superfície acarretando um aumento no desordenamento do InGaP e assim aumentando o gap do material.

Na figura 4.21 estão apresentados dois espectros de PL de InGaP- $p$, nesta camada como podemos observar que o pico é bem estreito, o que indica uma boa qualidade cristalina. A $F W H M$ desses picos é praticamente a mesma.
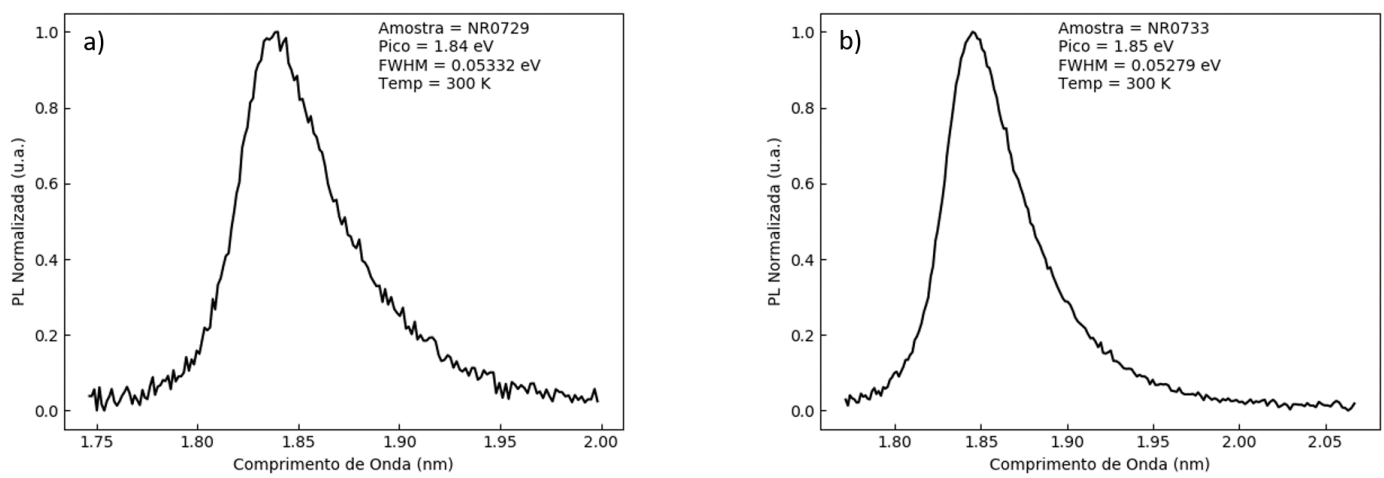

Figura 4.21: Espectros de PL obtidos para amostras de InGaP-p. A amostra do espectro (b) possui um fluxo de dopante aproximadamente duas vezes menor que o da amostra em (a).

Sobre as camadas de material quaternário temos na figura 4.22 um recorte da figura 4.3, onde podemos observar que a linha inferior corresponde às composições de InGaP e a linha superior corresponde às composições de AlInP. Desta forma podemos entender a formação do quaternário como o percentual de InGaP e AlInP. Podemos observar na figura uma linha pontilhada onde o parâmetro de rede é o mesmo do GaAs. Existem alguns gaps possíveis de AlGaInP que podem dar origem a material casado com GaAs. É através do pico de energia da PL que podemos calcular a composição desse quaternário.

Vale ressaltar que uma composição de AlGaInP casada com GaAs vai ter aproximadamente $50 \%$ de In, pois os dois ternários fornecem In, os outros $50 \%$ será divido entre Ga e Al. Lembro que o nosso objetivo para as duas camadas de quaternário é obter um gap com pelo menos $60 \mathrm{meV}$ a mais que a energia do gap da região ativa. O aumento do gap é dado pela incorporação de $\mathrm{Al}$ na estrutura, ou seja, quanto mais alumínio maior o gap porém, outro fator importante sobre a incorporação de Alumínio, é que materiais com Al são mais difíceis de se atingir dopagens tipo- $p$ mais altas. E a razão por optarmos por 


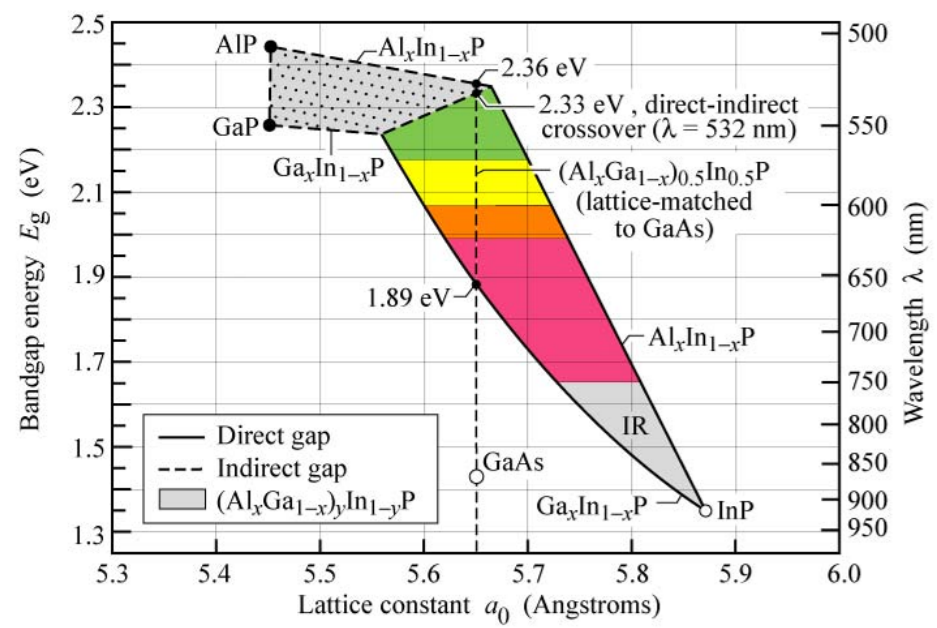

Figura 4.22: Recorte do gráfico de gap vs parâmetro de rede. (37)

substituir o AlInP (conforme citado no capítulo III) pelo AlGaInP, foi que o quaternário possui um percentual menor de AL em sua composição.

A composição casada do quaternário fica na forma $\left(A l_{y} G a_{1-y}\right)_{0,50} I n_{0,50} P$. Conforme já sabemos o cálculo da composição do AlGaInP é feito a partir do parâmetro de rede e do pico da PL. Os dois ternários que formam o quaternário fornecem In para a estrutura. Logo, o primeiro passo é calcular o percentual de In na estrutura. Para esse cálculo utilizamos a equação 4-8:

$$
a=G a P(1-x)+\operatorname{In} P(x)
$$

onde em $a$ inserimos o parâmetro de rede obtido através do DRx e $x$ é o percentual de In incorporado.

Sabendo o percentual de In, podemos calcular o gap do InGaP e do AlInP, utilizando as equações 4-9 (38):

$$
\left\{\begin{array}{l}
\operatorname{Al} \operatorname{In} P\left(E_{g}\right)=1,34+2,23(1-x) \\
\operatorname{In} \operatorname{GaP}\left(E_{g}\right)=1,34+1,15(1-x)
\end{array}\right.
$$

Com os gaps dos ternários, utilizamos o pico da PL na equação 4-10 para calcular o percentual de Ga e Al.

$$
y=\frac{E_{g}(P L)-E_{g}(\operatorname{In} G a P)}{E_{g}(A l \operatorname{In} P)-E_{g}(\operatorname{In} G a P)}
$$

Onde y é o valor utilizado para calcular o percentual de Ga e Al. 
Posto isso iniciamos a calibração do AlGaInP- $n$ baseados em um crescimento já realizado. Com a medida de PL das camadas de AlGaInP- $n$ obtivemos picos de aproximadamente 2,00 eV. As energias dos gaps encontradas estão de acordo com o que esperávamos para a camada janela, visto que esta camada deve ter $60 \mathrm{meV}$ acima do gap da região ativa. Com o resultado de descasamento a partir do Rx, calculamos as composições que estão apresentadas na tabela 4.6, e podemos observar que apesar de termos um aumento no descasamento das amostras as composições estão próximas do que seria uma composição casada. A tabela 4.6 é um resumo da calibração da camada da janela, os valores de dopagem serão discutidos logo em seguida.

\begin{tabular}{|c|c|c|c|c|}
\hline amostra & PL (eV) & $\begin{array}{c}\text { descasamento } \\
(\mathrm{ppm})\end{array}$ & $\begin{array}{c}\text { dopagem } \\
\left(\mathrm{x} 10^{18} \mathrm{~cm}^{-3}\right)\end{array}$ & composição \\
\hline 1 & 2,02 & $-544,8$ & 6 & $A l_{0,062} G a_{0,471} I n_{0,467} P$ \\
\hline 2 & 2,01 & $-824,9$ & 1,4 & $A l_{0,043} G a_{0,499} I n_{0,457} P$ \\
\hline 3 & 2,00 & $-862,5$ & 2,18 & $A l_{0,094} G a_{0,392} I n_{0,514} P$ \\
\hline
\end{tabular}

Tabela 4.6: Resumo dos resultados do crescimento do material quaternário.

O desafio desta calibração foi encontrar o fluxo de dopante para atingir a dopagem esperada. Na figura 4.23, estão apresentadas as amostras produzidas. Neste gráfico temos a dopagem medida vs o fluxo de dopante sobre o grupo III.

A dopagem obtida na primeira amostra foi da ordem de $6 x 10^{18} \mathrm{~cm}^{-3}$, muito acima do que esperávamos de acordo com as simulações (lembrando que o valor é $\left.2 x 10^{18} \mathrm{~cm}^{-3}\right)$. Então diminuímos a injeção de dopante à metade $\mathrm{e}$ o fluxo diminuiu de $1,02 \times 10^{-2}$ para $5,1 \times 10^{-3}$ sccm. Com essa modificação obtivemos uma dopagem da ordem de $1,4 x 10^{18} \mathrm{~cm}^{-3}$. Na terceira amostra aumentamos a injeção de dopante e o fluxo aumentou de $5,1 \times 10^{-3}$ para $7,29 \times 10^{-3} \mathrm{sccm}$. A dopagem ficou da ordem de $2,17 \times 10^{18} \mathrm{~cm}^{-3}$ mais próximo do que esperávamos de acordo com as simulações.

Por fim realizamos a calibração da camada de BSF, cujo material é o AlGaInP-p. A receita deste crescimento foi baseada em um crescimento já realizado no LabSem. As energias obtidas através dos picos de PL foram de aproximadamente 2,00 eV, valor este que está de acordo como o que esperávamos, pois semelhante à janela um BSF com gap maior que da região ativa fornece uma barreira maior para os portadores minoritários.

Através do Rx obtivemos o parâmetro de rede da camada crescida, e com essa informação em conjunto com a PL, calculamos as composições. A tabela 4.7 possui os valores de PL, descasamento, dopagem e composição. A dopagem será discutida logo em seguida à tabela apresentada. 


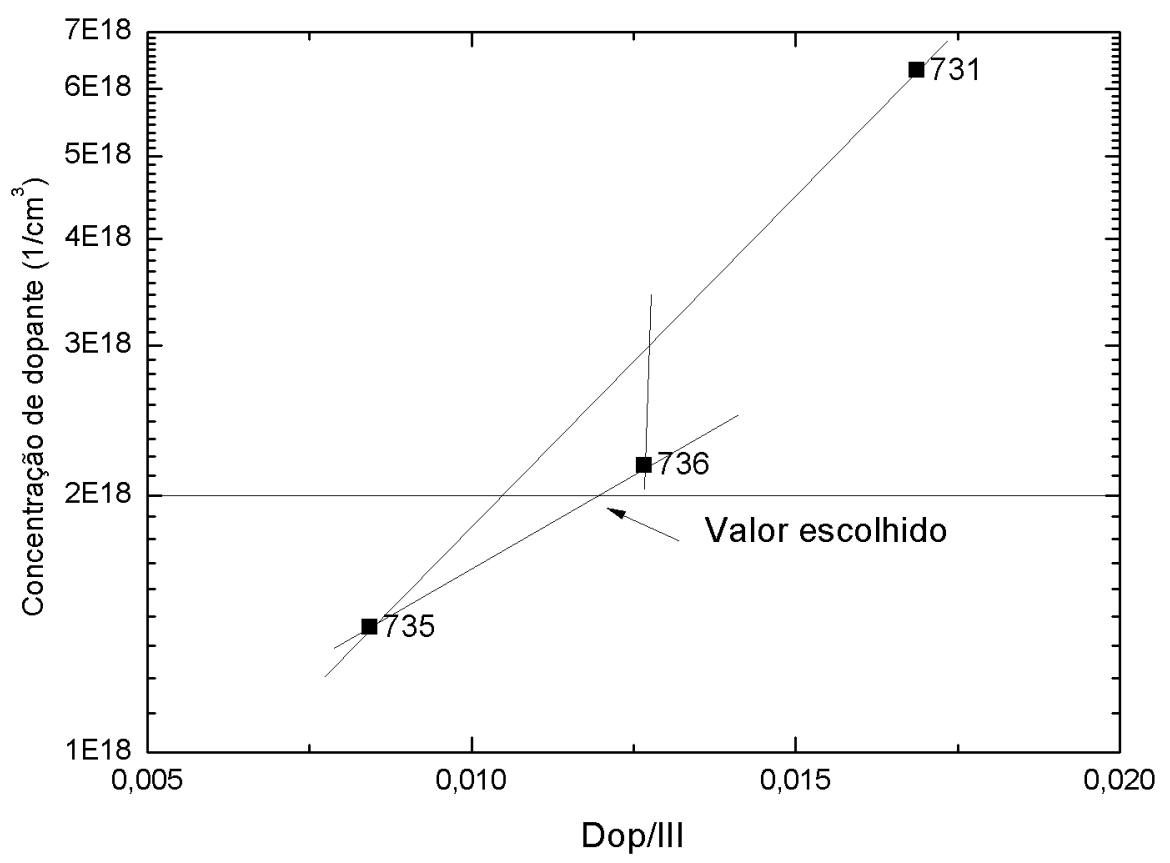

Figura 4.23: Dopagem vs razão do fluxo de dopantes sobre o grupo III para calibração do AlGaInP tipo- $n$.

\begin{tabular}{|c|c|c|c|c|}
\hline amostra & PL $(\mathrm{eV})$ & $\begin{array}{c}\text { descasamento } \\
(\mathrm{ppm})\end{array}$ & $\begin{array}{c}\text { dopagem } \\
\left(\mathrm{x} 10^{18} \mathrm{~cm}^{-3}\right)\end{array}$ & composição \\
\hline 1 & 2,00 & $-247,6$ & 0,285 & $A l_{0,065} G a_{0,447} \operatorname{In}_{0,487} P$ \\
\hline 2 & 2,00 & $-229,5$ & 0,323 & $A l_{0,055} G a_{0,467} I n_{0,477} P$ \\
\hline 3 & 1,99 & $-812,7$ & $\approx 1,3$ & $A l_{0,025} G a_{0,517} I n_{0,458} P$ \\
\hline
\end{tabular}

Tabela 4.7: Resumo dos resultados da calibração do crescimento do quaternário tipo $p$.

Nesta camada o desafio de dopar a camada conforme esperado de acordo com a simulação foi ainda maior. Na primeira amostra a dopagem obtida foi de $2,85 \times 10^{17} \mathrm{~cm}^{-3}$, esse resultado está aproximadamente uma ordem de grandeza menor que o resultado esperado que é da ordem de $3 x 10^{18} \mathrm{~cm}^{-3}$. Na segunda amostra de quaternário tipo- $p$ nós aumentamos o fluxo efetivo de dopante de 15,39 para $25 \mathrm{sccm}$, e mantivemos fixos os fluxos de: TMGa, TMAl, TMIn e $\mathrm{PH}_{3}$.

Com essa mudança a segunda amostra apresentou dopagem da ordem de $3,23 \times 10^{17} \mathrm{~cm}^{-3}$. Como podemos observar, não houve aumento significativo da dopagem conforme o esperado, devido à dificuldade de dopar tipo- $p$ materiais com Al. O fluxo de dopante $(25 \mathrm{sccm})$ estabelecido para esta amostra já representava o fluxo de DMZn máximo que o reator poderia fornecer.

A alternativa que nós utilizamos para o crescimento da terceira amostra 
de quaternário, foi repetir a receita anterior e fazer a dopagem via difusão. Conforme citado no tópico sobre MOVPE no início deste capítulo, o substrato é aquecido durante o crescimento. Então fizemos um buffer de GaAs super dopado, da ordem de $7 \times 10^{18} \mathrm{~cm}^{-3}$, que foi a fonte de Zn para a difusão.

Nesta amostra como pode ser observado na tabela 4.7 o descasamento aumentou significativamente, esse aumento muito grande é devido à incorporação de Zn, pois este "disputa"os sítios do grupo III. Outro fator que pode explicar esse descasamento foi que, por uma falha, a pressão do TMIn foi dobrada, porém, isso foi corrigido para a amostra final. Nesta amostra nós utilizamos a técnica de CV para obter a dopagem feita via difusão. A dopagem obtida foi de aproximadamente $1,3 \times 10^{18} \mathrm{~cm}^{-3}$, que ainda está abaixo do valor esperado de acordo com a simulação.

Devido ao descasamento apresentado nas últimas amostras crescidas de quaternário $n$ e $p$, nós utilizamos a teoria de Matthews e Blakeslee (39) para saber se alguma das camadas atingiriam a espessura crítica. Neste cálculo foram utilizados os valores de descasamento e o parâmetro de rede a fim de obter a espessura crítica. A equação utilizada foi:

$$
h_{C} \approx \frac{a}{2|\Delta a / a|}=\frac{a^{2}}{2|\Delta a|}
$$

onde $h_{C}$ é a espessura crítica e $\Delta a$ o descasamento.

$\mathrm{Na}$ tabela ?? também está apresentado um resumo com os valores obtidos da calibração para cada camada juntamente com as espessuras críticas, incluindo as camadas da região ativa.

\begin{tabular}{lcccc}
\hline & PL $(\mathrm{eV})$ & $\begin{array}{c}\text { dopagem } \\
\left(\mathrm{x} 10^{18} \mathrm{~cm}^{-3}\right)\end{array}$ & $\begin{array}{c}\text { espessura crítica } \\
(\mathrm{nm})\end{array}$ & $\begin{array}{c}\text { espessura crescida } \\
(\mathrm{nm})\end{array}$ \\
\hline AlGaInP-n & 2,00 & 2,18 & 328 & 20 \\
\hline InGaP-n & 1,86 & 1,44 & 1815 & $60 / 80 / 120$ \\
\hline InGaP-p & 1,85 & 0,19 & 1252 & 1000 \\
\hline AlGaInP-p & 1,99 & $\approx 1,2$ & 350 & 30 \\
\hline
\end{tabular}

Tabela 4.8: Resumo dos resultados das calibrações.

Estes resultados estão de acordo com nossas expectativas, pois o gap das camadas da região ativa estão próximos de 1,84 eV. Os gaps dos quaternários estão acima de $60 \mathrm{meV}$ que era o valor mínimo esperado para as camadas de janela e BSF. Conforme a calibração conseguimos obter uma dopagem próxima do que era esperado pela simulação, exceto pela dopagem do BSF. E apesar do descasamento encontrado nenhuma das camadas atingiu a espessura crítica. 
Das amostras finais foram crescidas 3 estruturas cuja diferença foi a espessura da camada emissora. Os valores de espessura crescidos foram 60 , 80 e $120 \mathrm{~nm}$. Na figura 4.24 estão as estruturas crescidas conforme o resultado obtido na simulação.
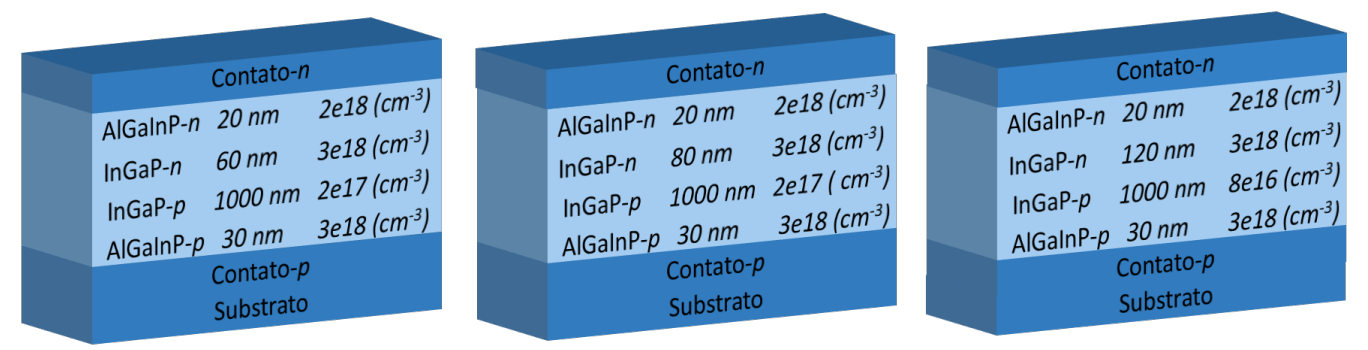

Figura 4.24: Representação das amostras crescidas a partir da estrutura escolhida. Com modificação na camada do emissor.

\subsection{2}

\section{Processamento}

Agora passemos aos resultados do processamento. A primeira etapa do processamento foi a fotolitografia, na figura 4.25 está apresentada a microscopia óptica dos padrões obtidos. Como podemos observar o resultado é de boa qualidade, pois o contorno dos padrões da máscara é bem definido. Este é um indicativo de que a calibração foi bem sucedida.

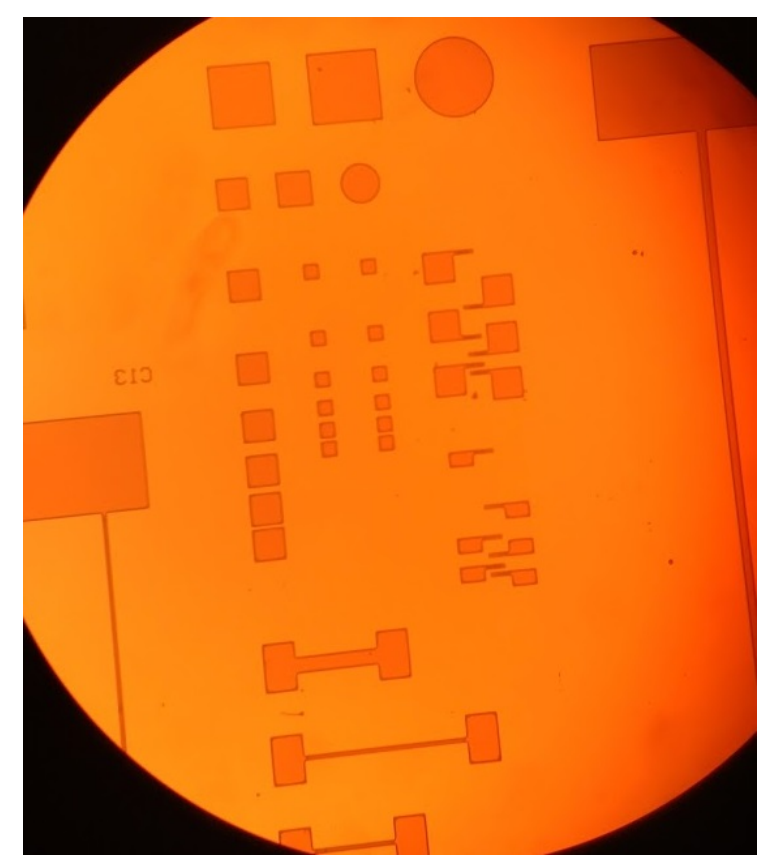

Figura 4.25: Microscopia ótica das figuras de TLM obtidas através no processo de fotolitografia.

$\mathrm{Na}$ corrosão das mesas encontramos alguns problemas. Na calibração nós verificamos a taxa de corrosão para cada camada. A taxa da camada de 
GaAs não apresentou divergência quanto ao que foi definido na calibração. No entanto, as camadas de InGaP e quaternário apresentaram divergência na taxa de corrosão antes estipulada. Após cada corrosão, foi realizada uma medida com perfilômetro a fim de verificar a espessura corroída. Porém, de acordo com a espessura medida, algumas amostras não teriam chegado à profundidade desejada.

Na figura 4.26 estão apresentados dois perfis de corrosão: um que corroeu a altura total de acordo com o perfilômetro e outro que não atingiu a profundidade correta.
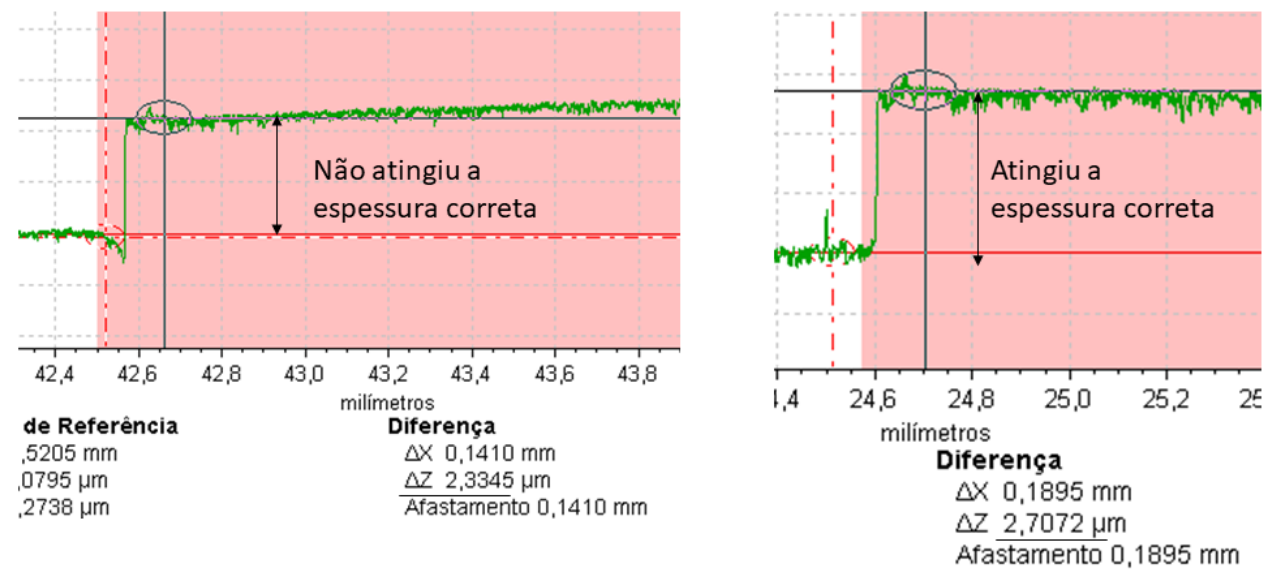

Figura 4.26: Perfis da altura corroída das camadas obtidos no perfilômetro mecânico.

Sobre esses perfis de corrosão é preciso ressaltar que a espessura do fotorresiste era de aproximadamente 1,6 $\mathrm{m}$ e a profundidade a ser corroída era de $1,2 \mu \mathrm{m}$. Logo, a amostra que atingiu a profundidade de $2,7 \mu \mathrm{m}$ conseguiu corroer toda a estrutura, e a outra amostra que atingiu o valor de 2,33 $\mu \mathrm{m}$ não chegou a profundidade correta. Esta amostra foi deixada 1 minuto a mais na solução de corrosão e não houve mais corrosão. Devido a essa paralisação na corrosão, foi assumido que a mesma havia chegado ao fim, pois a corrosão escolhida foi do tipo seletiva.

Sobre a metalização dos contatos, são apresentados em seguida os valores obtidos através da técnica de TLM.

Os valores de resistência de contato apresentados na tabela 4.9 foram obtidos a partir das curvas de TLM apresentadas nas figuras 4.27 e 4.28.

Como podemos observar através da tabela 4.9 os contatos tipo $p$ apresentaram resistência semelhante. No entanto, o contato tipo- $n$ processado no LNMS apresentou uma resistência de contato menor. Essa diferença é devido ao tratamento térmico rápido (RTA Rapid Thermal Anneling). Este tratamento é feito com o intuito de melhorar o contato, ou seja, reduzir a resistência. Essa 


\begin{tabular}{|c|c|c|c|}
\hline Processamento & Tipo & Contato & Resistência de contato $(\Omega)$ \\
\hline LNMS & $n$ & Ôhmico & $6,08+-0,69$ \\
\hline LNMS & $p$ & Ôhmico & $22,26+-3,17$ \\
\hline LabSem & $n$ & Schottky & $19,25+-0,39$ \\
\hline LabSem & $p$ & Ôhmico & $22,28+-3,17$ \\
\hline
\end{tabular}

Tabela 4.9: Melhores valores de resistências de contato obtidas através da medida de TLM.

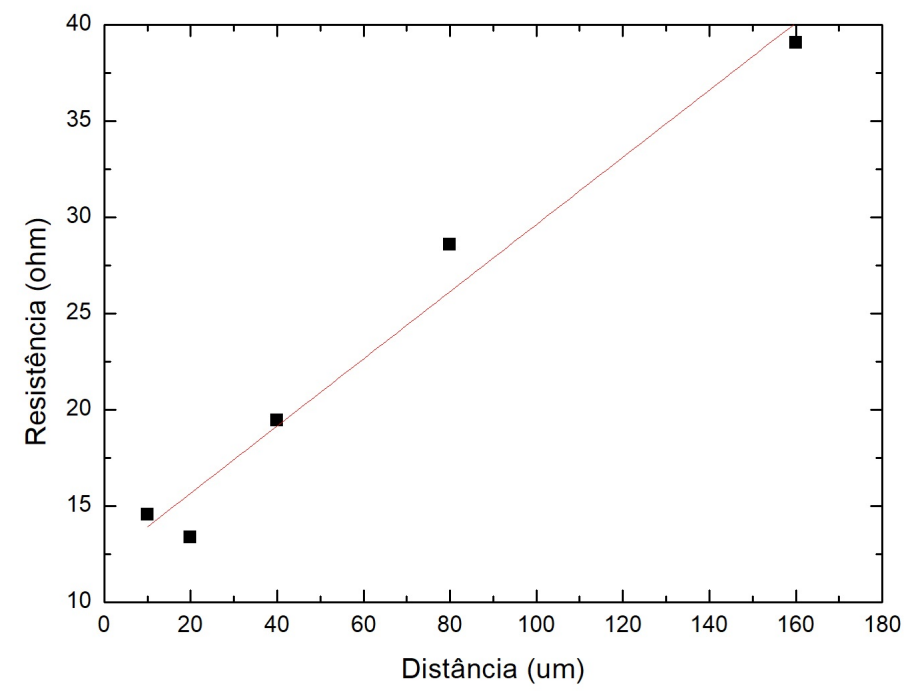

Figura 4.27: Curva de resistência vs distância, obtidas a partir das medidas de TLM para o contato $n$.

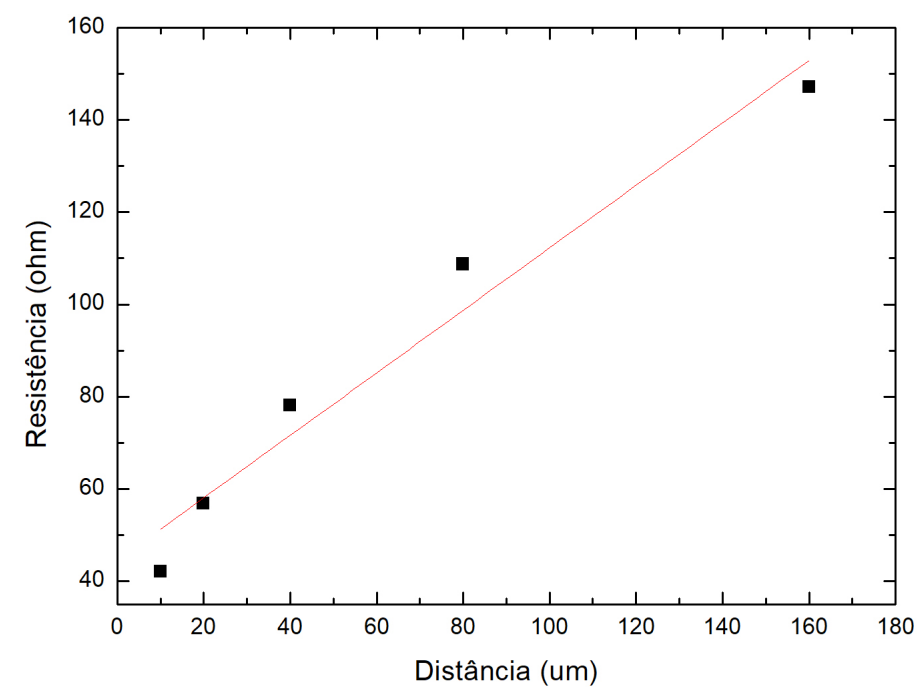

Figura 4.28: Curva de resistência vs distância, obtidas a partir das medidas de TLM para o contato tipo $p$. 
melhora acontece, pois ocorre uma pequena difusão do metal para dentro da camada de contato e também ocorre a formação de uma liga entre os metais que compõem o contato. No caso do contato produzido no LabSem o RTA foi feito a uma temperatura de $420^{\circ} \mathrm{C}$ por $5 \mathrm{~min}$, este tratamento acabou produzindo um contato com tendência a uma barreira Schottky, já no LNMS o RTA feito teve temperatura de $520^{\circ} \mathrm{C}$ por $30 \mathrm{seg}$, este contato ficou ôhmico.

Mais sobre o processamento será discutido no próximo capítulo, pois reflete diretamente na qualidade das amostras produzidas. 


\section{5 \\ Caracterização do dispositivo}

Neste capítulo será abordada a caracterização dos dispositivos produzidos. Iniciaremos com uma explicação básica das técnicas utilizadas na caracterização que são: curva de corrente vs tensão sob iluminação, corrente vs tensão no escuro e a eletroluminescência. Por fim passaremos aos resultados e discussões.

\section{1}

\section{Técnicas de caracterização}

\subsection{1}

\section{Curva corrente vs tensão sob iluminação}

Através da curva $I V$ apresentada na figura 2.7 na página 29, podemos obter os seguintes resultados: a corrente de curto circuito $\left(I_{s c}\right)$, a tensão de circuito aberto $\left(V_{o c}\right)$, o fill factor, a eficiência de conversão da célula $(\eta)$, a corrente na potência máxima $\left(I_{m p}\right)$, tensão na potência máxima $\left(V_{m p}\right)$ e a potência máxima que o dispositivo é capaz de fornecer. Além dessas informações supra citadas, a curva $I V$, através da sua forma, pode nos fornecer informações como efeitos resistivos que também já foram apresentados na figura 2.8 na página 31.

A figura 5.1 é uma representação esquemática da montagem utilizada para fazer a medida $I V$. Este aparato pode ser utilizado para a medir o $I V$ do dispositivo no escuro, retirando o simulador solar e protegendo o dispositivo de qualquer fonte luminosa.

Como apresentado na figura, a montagem possui um simulador solar e a fonte de potência utilizada foi um analisador de parâmetros semicondutores da HP, modelo HP4145B, que aplica uma diferença de potencial entre os contatos do dispositivo e mede a corrente produzida. Estes dados são coletados por um software que os salva. 


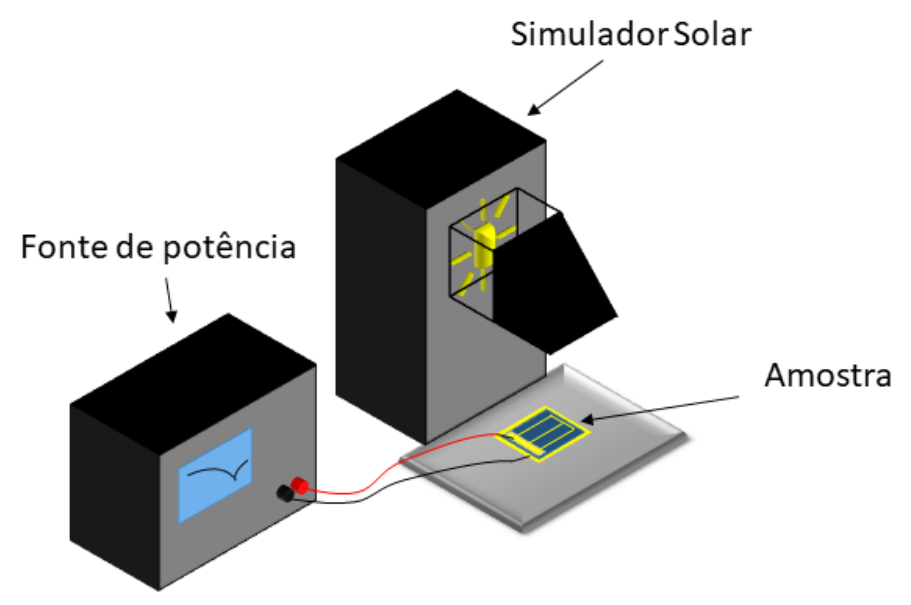

Figura 5.1: Esquema da montagem utilizada para medir a curva $I V$.

\section{1 .2}

\section{Curva corrente vs tensão no escuro}

Como a função das células solares é converter energia luminosa em energia elétrica, não parece interessante medir estes dispositivos no escuro. No entanto, medidas $I V$ no escuro são de grande valor na análise das propriedades do diodo. Uma simples medição de $I V$ no escuro produz a curva exponencial característica do diodo. A equação da célula ideal no escuro, ou seja, sem considerar os efeitos resistivos é dada pela equação 5-1.

$$
I=I_{0}\left(e^{\frac{q V}{n k T}}-1\right)
$$

onde $\mathbf{n}$ é o fator de idealidade. Acima de $100 m V$ o termo -1 pode ser desconsiderado e a equação se torna:

$$
I=I_{0}\left(e^{\frac{q V}{n k T}}\right)
$$

A curva $I V$ de escuro plotada em escala linear nos fornece muitas informações sobre o dispositivo, entretanto, esta mesma curva $I V$ em escala semilog facilita observação e aquisição dos resultados. Então aplicando o logaritmo em ambos os lados da equação 5-2 ela fica apresentada como na equação 5-3.

$$
\log (I)=\log \left(I_{0}\right)+\left(\frac{q V}{n k T}\right)
$$

Deste modo podemos obter facilmente o fator de idealidade através do 
coeficiente angular da curva log $I V$. O fator de idealidade é uma função da tensão. Este fator é próximo de 1 a altas tensões, e a baixas tensões o fator se aproxima de 2 , pois a recombinação na região de depleção é dominante. A modelagem do circuito equivalente foi apresentada no capítulo 2.

A curva de escuro em semilog está apresentada na figura 5.2, onde podemos observar a região afetada pelos efeitos resistivos, e também a obtenção do fator de idealidade.

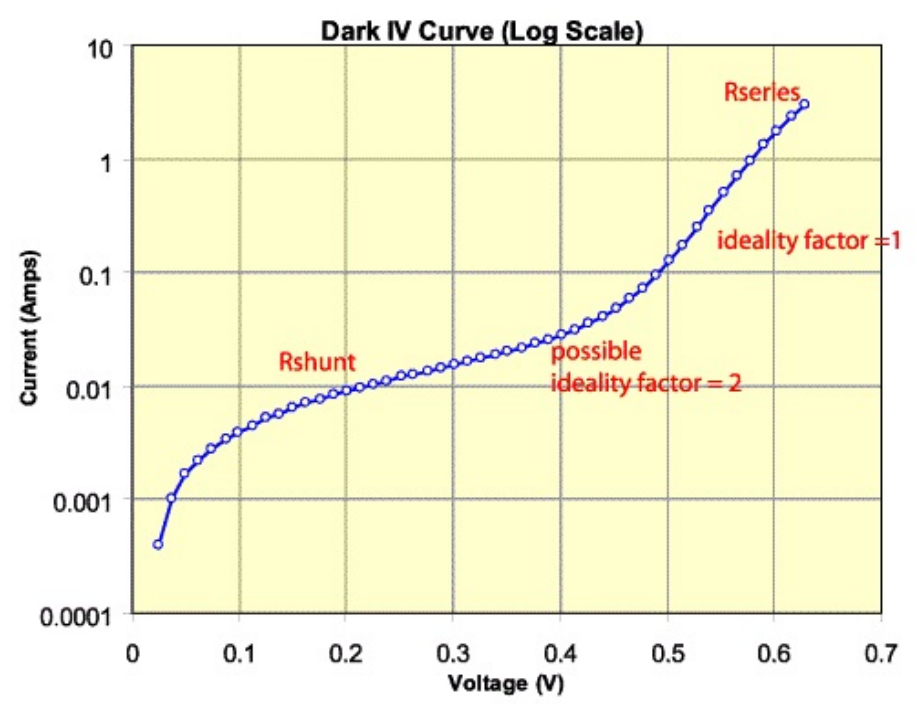

Figura 5.2: Curva ilustrativa da corrente de escuro de uma célula solar com as indicações das regiões das resistências e os fatores de idealidade. Fonte:(40)

A partir desta curva podemos observar através do grau de curvatura da curva em correntes mais altas, o efeito da resistência em série. Semelhantemente a curvatura a correntes menores indica uma baixa resistência shunt (42).

\subsection{3}

\section{Eletroluminescência}

A medida de eletroluminescência é baseada no princípio de funcionamento de um diodo emissor de luz (LED). Uma corrente é fornecida a uma célula solar e a recombinação radiativa de portadores causa emissão de luz. Utilizando uma câmera apropriada podemos capturar a imagem do dispositivo emitindo radiação. A emissão ocorre em um comprimento de onda próximo do gap do material. Com eletroluminescência é possível observar a uniformidade das recombinações do dispositivo. O esquema experimental está apresentado na figura 5.3 e é bem simples, possuindo apenas uma fonte de corrente e a câmera para aquisição das imagens. 


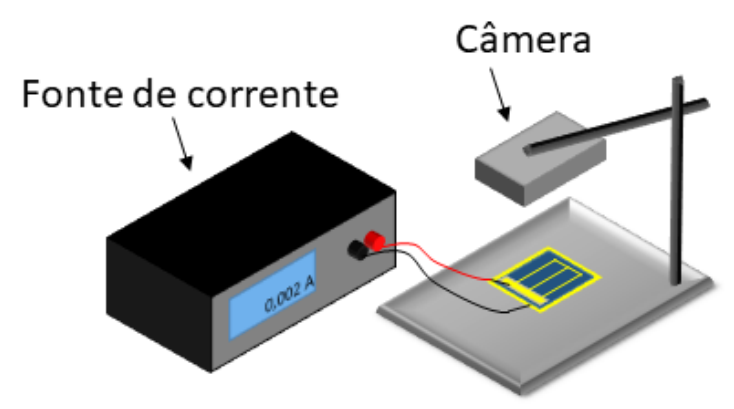

Figura 5.3: Esquema da montagem utilizada para obter as imagens de eletroluminescência.

\section{2}

Resultados

\subsection{1}

\section{Curva corrente vs tensão sob iluminação}

Nesta seção serão apresentadas as curvas $J V$ e as figuras de mérito das células solares. Apenas relembrando que uma das células foi processada em nosso laboratório e as demais foram produzidas no LNMS da USP. As amostras serão identificadas a partir das seguintes legendas: local onde foi processada ("1"para o LabSem e "2"para o LNMS), o número da mesa e a espessura do emissor, por exemplo, 1-06-60.

Comecemos a apresentação dos resultados com as células que foram processadas no LabSem. Na figura 5.4 estão apresentadas as curvas $J V$ da amostra que foi processada no LabSem. E na sequência, nas tabelas 5.1 e 5.2 , estão apresentadas, respectivamente, as figuras de mérito e as resistências obtidas.

\begin{tabular}{|c|c|c|c|c|}
\hline Amostra & Jsc $\left(\mathrm{mA} / \mathrm{cm}^{2}\right)$ & Voc $(V)$ & Fill Factor $(\%)$ & Eficiência $(\%)$ \\
\hline $1-03-60$ & 7,77 & 1,30 & 79,06 & 5,92 \\
\hline $1-06-60$ & 8,21 & 1,28 & 71,72 & 5,59 \\
\hline $1-14-60$ & 8,46 & 1,32 & 74,70 & 6,19 \\
\hline
\end{tabular}

Tabela 5.1: Figuras de mérito obtidas das células processadas no LabSem.

\begin{tabular}{|c|c|c|}
\hline Amostra & Resistência shunt $\left(\Omega \mathrm{cm}^{2}\right)$ & Resistência em série $\left(\Omega \mathrm{cm}^{2}\right)$ \\
\hline $1-03-60$ & $12,83 \mathrm{k}$ & 17,27 \\
\hline $1-06-60$ & $3,08 \mathrm{k}$ & 20,49 \\
\hline $1-14-60$ & $115,25 \mathrm{k}$ & 20,28 \\
\hline
\end{tabular}

Tabela 5.2: Valores de resistências das amostras processadas no LabSem.

A $V_{o c}$ média obtida nestas células é 1,30 $V$. Este valor é aproximadamente $5 \%$ menor do que o esperado de acordo com a simulação. Os FFs obtidos estão 


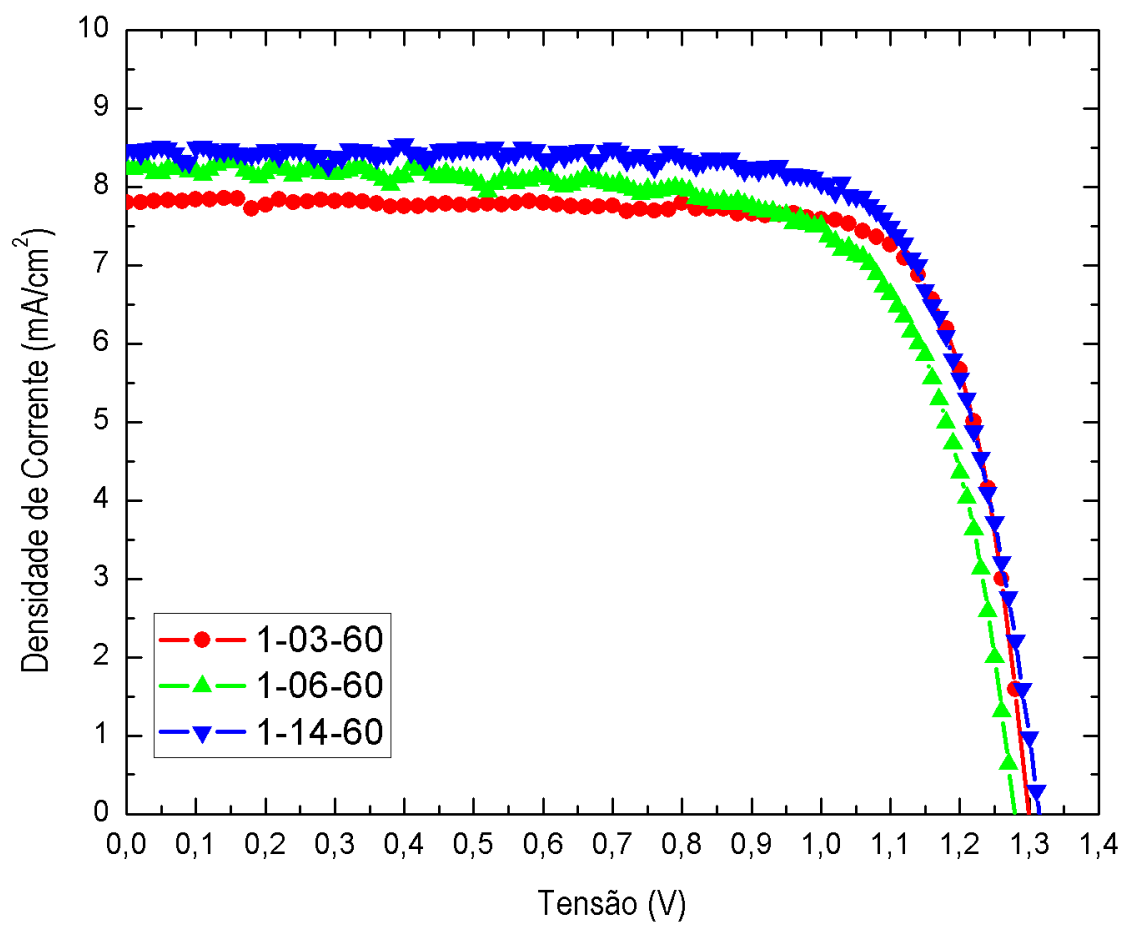

Figura 5.4: Curva $J V$ para a amostra produzida no LabSem. A diferença entre as curvas de são as quantidades de fingers e a área da mesa.

em torno de $75 \%$, este valor é $17 \%$ menor do que o valor obtido na simulação. No entanto, o valor $90 \%$ de $F F$ obtido na simulação é super estimado, pois ainda não é possível atingir este valor experimentalmente. Então comparando o $F F$ obtido experimentalmente com o $F F$ de $86 \%$ de uma célula com recorde de eficiência (41), vemos que nosso valor está adequado, pois está apenas 11\% menor.

Antes de comparar as correntes medidas com a corrente simulada é preciso fazer uma consideração. O software de simulação não considera reflexões na superfície, logo, para que a comparação entre as correntes seja válida é preciso descontar $30 \%$ do valor da corrente simulada, pois este é mais ou menos o percentual de perdas por reflexões na superfície de uma célula sem camada anti-reflexiva. Logo, o valor de $21,47 \mathrm{~mA} / \mathrm{cm}^{2}$ obtido na simulação, considerando as reflexões, se torna 15,03 $\mathrm{mA} / \mathrm{cm}^{2}$. Então, comparando a densidade de corrente obtida experimentalmente, ela é aproximadamente $50 \%$ menor do que a densidade de corrente corrigida. A este valor baixo de corrente nós atribuímos a resistência em série $\left(\mathrm{R}_{s}\right)$ associada à amostra. Os valores de $\mathrm{R}_{s}$ apresentados na tabela 5.2 estão próximos de $20 \Omega \mathrm{cm}^{2}$ que é uma resistência muito alta, já que idealmente este valor é nulo. A baixa dopagem do BSF é outro fator 
que pode estar contribuindo para esta corrente baixa, pois não conseguimos atingir a dopagem esperada para esta camada. Se a dopagem é menor, o campo elétrico produzido pelo BSF será menor, aumentando a probabilidade de recombinação nas regiões em que o portador tenha que percorrer, ou seja, uma distância eventualmente maior que o comprimento de difusão. E ainda um último fator que está contribuindo para esta corrente baixa, é o underetching que ocorreu na região das mesas. Este problema faz com que a área de absorção da célula seja menor, logo, haverá uma diminuição na absorção de fótons.

Sobre as amostras processadas no LNMS, estão apresentadas na figura 5.5 as curvas $J V$ obtidas e na tabela 5.3 e 5.4 estão apresentadas as figuras de mérito e as resistências.

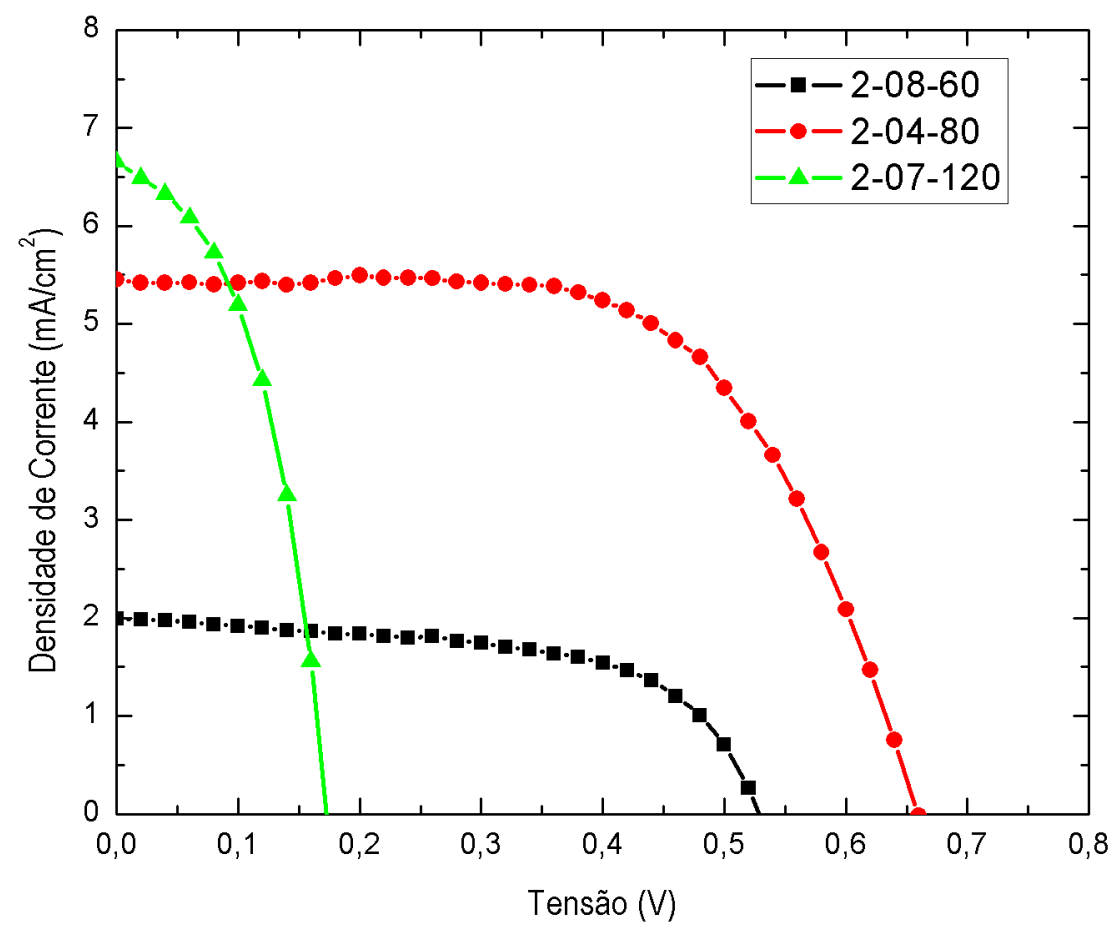

Figura 5.5: Curvas $J V$ de amostras processadas no LNMS. As curvas preta, vermelha e verde possuem emissor com 60, 80 e $120 \mathrm{~nm}$ de espessura, respectivamente.

\begin{tabular}{|c|c|c|c|c|}
\hline Amostra & Jsc $\left(\mathrm{mA} / \mathrm{cm}^{2}\right)$ & Voc $(V)$ & Fill Factor $(\%)$ & Eficiência (\%) \\
\hline $2-08-60$ & 1,98 & 0,49 & 63,2 & 0,45 \\
\hline $2-04-80$ & 5,45 & 0,67 & 61,25 & 1,66 \\
\hline $2-07-120$ & 6,65 & 0,17 & 47,87 & 0,40 \\
\hline
\end{tabular}

Tabela 5.3: Figuras de mérito das células processadas no LNMS. 


\begin{tabular}{|c|c|c|}
\hline Amostra & Resistência shunt $\left(\Omega c m^{2}\right)$ & Resistência em série $\left(\Omega c m^{2}\right)$ \\
\hline $2-08-60$ & $1,23 \mathrm{k}$ & 37,55 \\
\hline $2-04-80$ & $12,40 \mathrm{k}$ & 32,66 \\
\hline $2-07-120$ & 71,02 & 11,27 \\
\hline
\end{tabular}

Tabela 5.4: Resistências em série e shunt das amostras processadas no LNMS.

As três células solares da figura 5.5 possuem o mesmo processamento, a diferença entre cada curva é a espessura do emissor. As densidades de corrente destas curvas ficaram bem abaixo do esperado de acordo com a simulação. No entanto, comparando o $I V$ da amostra 2-08-60 com a curva da amostra 2-04-80, vemos que a segunda célula apresentou uma corrente maior, como esperado. De acordo com as simulações uma estrutura com $80 \mathrm{~nm}$ de espessura do emissor de fato fornece uma corrente maior. A estrutura que possui a espessura do emissor de $80 \mathrm{~nm}$ deveria apresentar a maior corrente por ser a estrutura otimizada. Porém, a amostra 2-07-120 que possui o emissor com uma espessura de $120 \mathrm{~nm}$ apresentou uma corrente maior. Para explicar esse resultado podemos utilizar a relação de Einstein que está dada na equação 5-4:

$$
\frac{D_{p}}{\mu_{p}}=\frac{D_{n}}{\mu_{n}}=\frac{k_{B} T}{e}
$$

Nesta equação temos a relação entre a mobilidade do portador e o coeficiente de difusão, que, por sua vez, está atrelado ao comprimento de difusão. Então se a mobilidade da camada do emissor é maior, o comprimento de difusão será maior aumentando a corrente fotogerada. O aumento da espessura só irá afetar a corrente quando ela for maior que o comprimento de difusão do portador minoritário. Então para comprovar, esta hipótese fizemos novamente uma simulação da estrutura da célula variando a espessura do emissor, porém, com uma mobilidade 1 ordem de grandeza maior que a utilizada no processo de otimização. O resultado desta simulação está apresentado no figura 5.6, onde podemos comprovar que de fato com a mobilidade alta a corrente aumenta junto com a espessura da camada. Com este resultado confirmamos também que a camada de emissor crescida é de boa qualidade, pois os portadores de corrente possuem uma mobilidade alta nela.

Na figura 5.7 está apresentada a curva $J V$ da célula 2-07-120, e nela, os efeitos das resistências (em série e shunt) ficam muito evidentes.

A célula 2-07-120 apresenta um valor $\mathrm{R}_{s}$ aproximadamente $50 \%$ menor que as demais células. Entretanto, notamos uma resistência $\operatorname{shunt}\left(\mathrm{R}_{s h}\right)$ com 


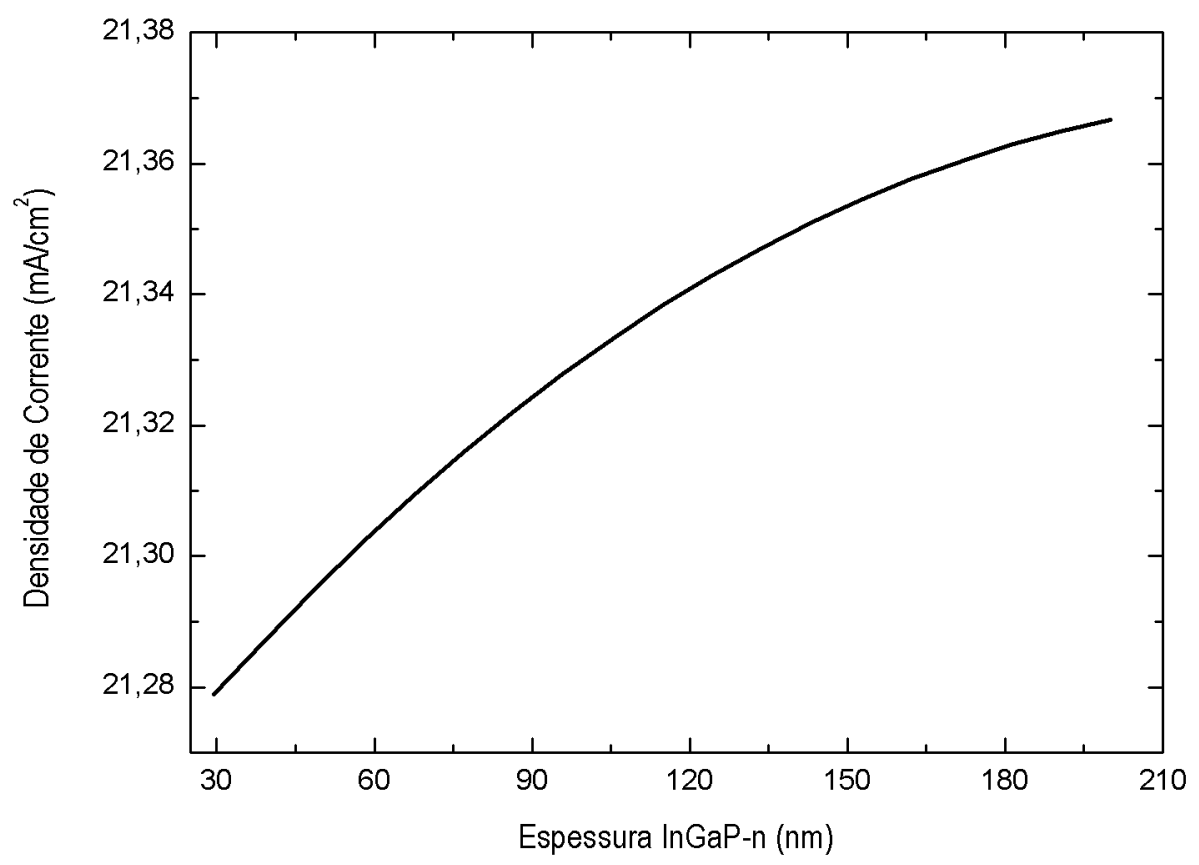

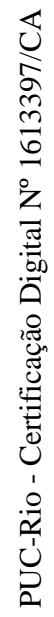

Figura 5.6: Curva $J_{s c}$ vs espessura de InGaP-n resultado de nova simulação realizada com o aumento da mobilidade da camada.

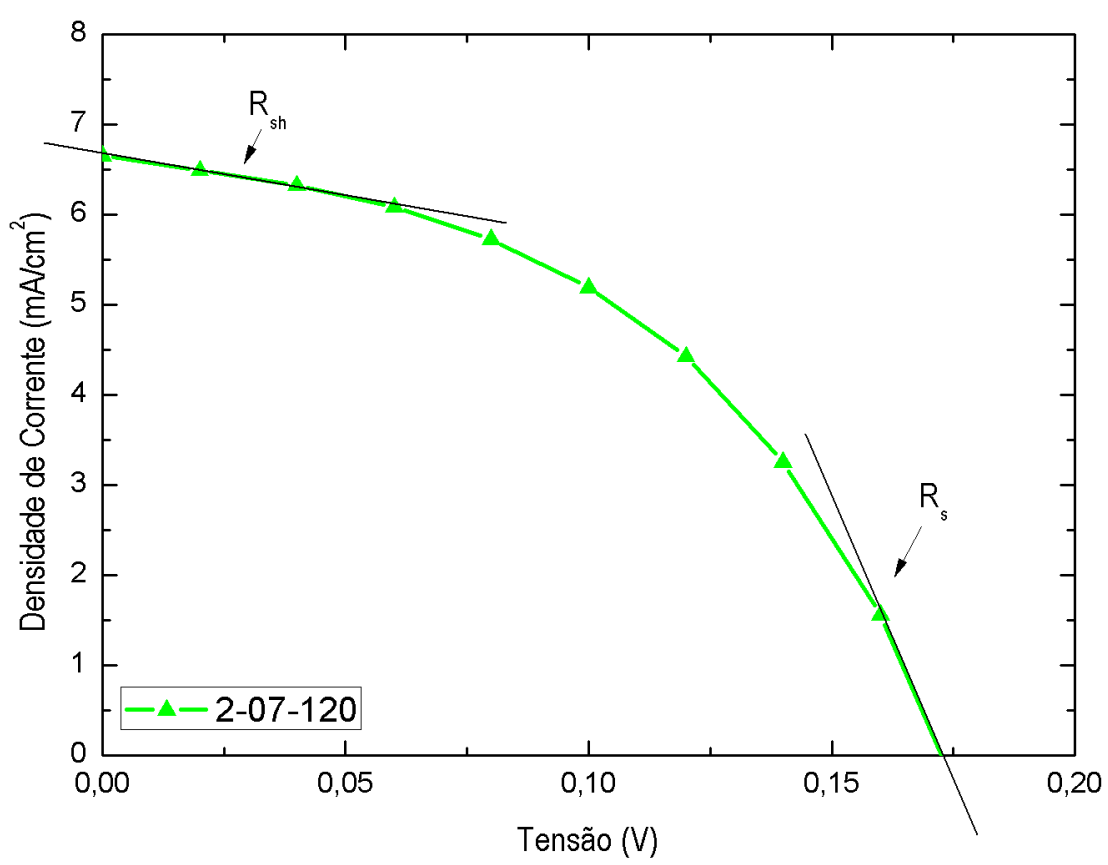

Figura 5.7: Curva $J V$ referente a amostras 2-07-120 com as indicações das regiões onde foram calculadas $\mathrm{R}_{s}$ e $\mathrm{R}_{s h}$. 
valor muito baixo em relação ao ideal. Com esses valores de resistências podemos explicar o FF abaixo de 50\%. Os FFs das células 2-08-60 e 2-0480 foram pouco maior que $60 \%$, a este valor podemos atribuir ao efeito da $\mathrm{R}_{s}$ associado. Podemos confirmar isto, visto que, na tabela 5.4 os valores de $R_{s h}$ foram bem elevados, conforme o esperado.

Conforme apresentado na figura 2.8 (capítulo 2, página 31), sabemos que a $\mathrm{R}_{\text {sh }}$ afeta diretamente a $\mathrm{V}_{o c}$. Ao comparar as $\mathrm{R}_{s h}$ obtidas, a célula que obteve o maior valor de $\mathrm{R}_{s h}$ foi a 2-04-80, que também obteve, conforme o esperado, a maior $\mathrm{V}_{o c}$.

Ao comparar as figuras de mérito das células de ambos os processamentos, observamos que as células processadas no LabSem apresentaram um resultado melhor. No intuito de compreendermos mais os resultados aqui obtidos, em relação às figuras de mérito obtidas realizamos a medida $J V$ no escuro. Esta medida nos fornece as características de diodo da célula solar e os resultados serão apresentados e discutidos a seguir.

\section{2 .2}

\section{Curva corrente vs tensão no escuro}

Na figura 5.8 está apresentada a curva de escuro para uma das células processadas no LabSem e na figura 5.9 estão apresentadas as curvas de escuro para as células processadas no LNMS.

A curva apresentada na figura 5.2, nos indica as regiões onde estão presentes os efeitos das resistências e o fator de idealidade. Comecemos pelo fator de idealidade. Podemos observar na curva $I V$ da figura 5.8 da amostra 107-60, o fator de idealidade obtido é igual a 2, isto indica que as recombinações estão acontecendo na região de depleção. Nas curvas apresentadas na figura 5.9 a curva da amostra 2-04-80 forneceu um fator de idealidade igual a 1,3. Este valor indica que a maior parte das recombinações está acontecendo nas regiões $p$ e $n$. Para as demais amostras o fator encontrado foi maior que 2. O artigo (43) discute sobre o fator de idealidade acima de 2 em células comerciais de Si. Os autores indicam que a resistência shunt e recombinação multi-nível estão relacionados a este fator maior que 2. No entanto, podemos observar outros detalhes sobre as curvas de escuro, por exemplo, a corrente de saturação do diodo. A corrente de saturação para a célula processada no LabSem foi menor do que para as demais células. Este comportamento corrobora com o fato desta célula apresentar uma $V_{o c}$ maior. Podemos observar a relação entre a corrente de saturação, $I_{0}$, e a $V_{o c}$ através da equação 5-5: 


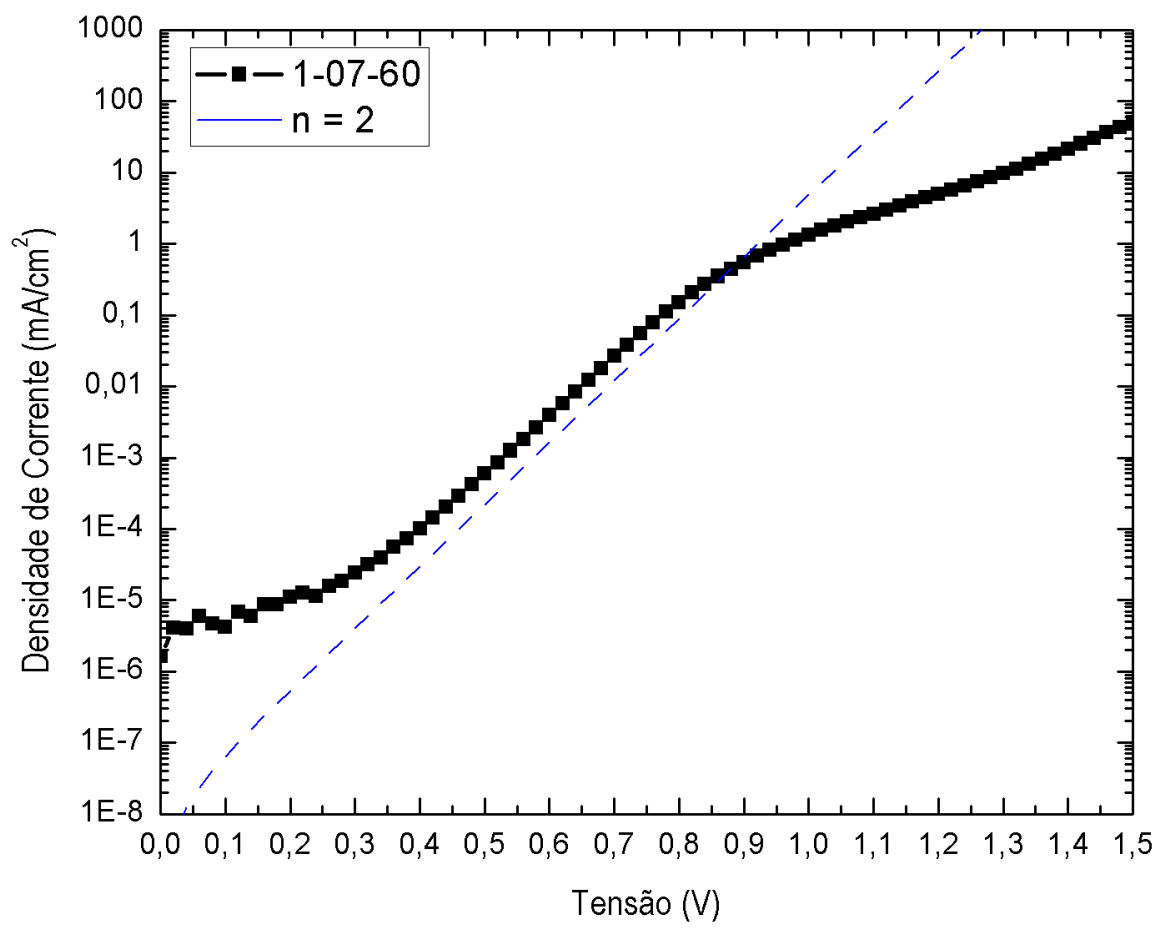

Figura 5.8: Corrente de escuro da célula processada no LabSem. Este dispositivo possui $60 \mathrm{~nm}$ de emissor e mesma quantidade de fingers que as amostras produzidas no LNMS. A linha azul tracejada é referente ao fator de idealidade obtido.

$$
V_{o c}=\frac{k T}{q} \ln \left(\frac{I_{s c}}{I_{0}}+1\right)
$$

onde $I_{0}$ é a corrente de saturação. Se $I_{0}$ apresenta um valor muito alto minimiza o logaritmo, e com isso diminui o valor da $V_{o c}$.

Ao comparar as correntes de escuro entre as amostras processadas no LNMS, podemos observar que a célula 2-04-80 apresenta uma corrente de saturação menor e a mesma possui a maior $V_{o c}$ dentre elas. A célula 2-0860 possui um corrente de saturação e uma $V_{o c}$ intermediárias entre as três células de igual processamento. E para a célula 2-08-120, que apresentou a menor $V_{o c}$, obtivemos a maior corrente de saturação.

Em relação à resistência shunt podemos observar seu efeito nas regiões de baixas tensões, onde a curvatura da curva pode nos dizer muito sobre a magnitude dos efeitos dessa resistência. Conforme apresentado no tópico anterior, as amostras 1-07-60 e 2-04-80 apresentaram as maiores $R_{s h}$, seguidas da amostra 2-08-60 e, por fim, a amostra 2-07-120 que apresentou a menor $\mathrm{R}_{s h}$ 


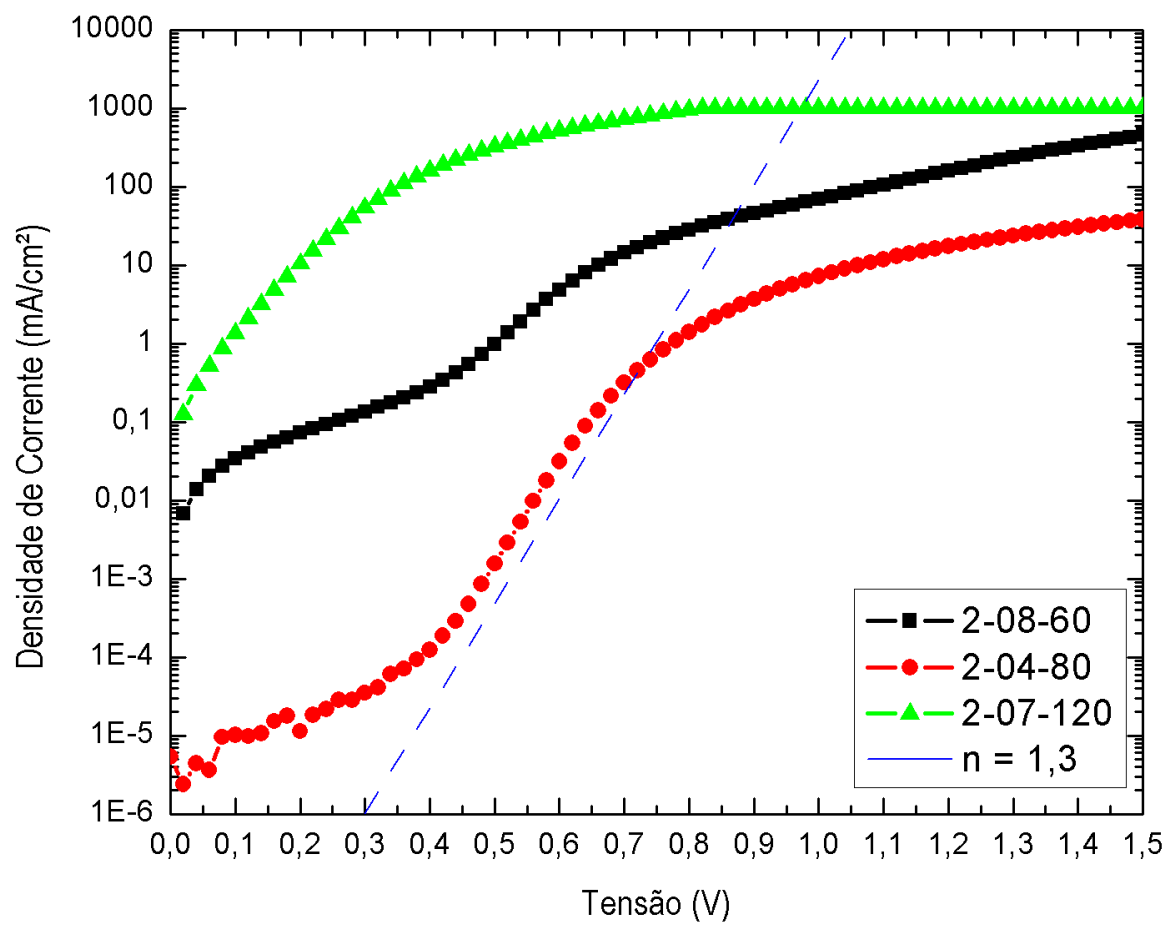

Figura 5.9: Corrente de escuro das células processadas no LNMS. As curvas preta, vermelha e verde possuem emissor com 60, 80 e $120 \mathrm{~nm}$ de espessura respectivamente. A linha azul tracejada é referente ao fator de idealidade obtido.

dentre todas as células. As curvas de corrente de escuro obtidas corroboram com este resultado, pois como podemos observar para as amostras 1-07-60 e 2-04-80 a corrente tende a um valor constante a baixas tensões. Na região de baixas tensões a amostra 2-08-60 apresenta uma leve curvatura e a amostra 2-07-120 apresenta uma grande curvatura, conforme esperado, dado que as $\mathrm{R}_{s h}$ calculadas são pequenas.

$\mathrm{A} \mathrm{R}_{s}$ afeta a curva na região de alta tensão. Quanto menor a inclinação nesta região maior esse efeito resistivo. Como podemos observar nas curvas de escuro, vemos que todas as amostras apresentam uma pequena inclinação indicando, um efeito importante da resistência. Vale ressaltar que a curva da amostra 2-07-120 apresentou saturação na região da $\mathrm{R}_{s}$.

Como podemos observar, a amostra 1-07-60 foi a única que conseguimos obter o fator de idealidade entre 1 e 2 . Então para compreender o comportamento dos efeitos de recombinação das amostras, nós utilizamos a técnica de eletroluminescência, cujos resultados serão abordados na próxima seção. 


\section{2 .3}

\section{Eletroluminescência}

As amostras 2-08-60 e 2-07-120 não apresentaram luminescência. Então serão apresentadas e comparadas a célula processada no LabSem e a célula que possui emissor de $80 \mathrm{~nm}$ que foi processada no LNMS. Estão apresentadas na figura 5.10 duas imagens obtidas das amostras 1-08-60 e 2-04-80. Nestas imagens ambas amostras foram alimentadas com a mesma corrente de 3,2 $m A$.

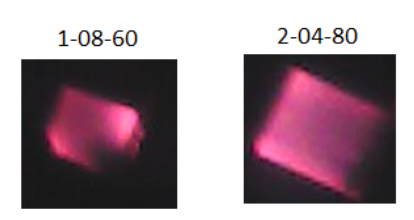

Figura 5.10: Eletroluminescência das células 1-08-60 e 2-04-80. Ambas amostras excitadas com a mesma corrente. A amostra 1-08-60 possui $60 \mathrm{~nm}$ no emissor e foi processada no LabSem, já a amostra 2-04-80 possui $80 \mathrm{~nm}$ no emissor e foi processada no LNMS.

Como podemos observar, com a mesma corrente aplicada, a célula 204-80 apresentou uma luminescência mais uniforme, no entanto, a amostra 1-08-60 apresentou uma luminescência mais intensa. Podemos utilizar o valor do fator de idealidade para explicar essa luminescência mais intensa, pois a amostra 1-08-60 apresentou $n=2$ que indica que as recombinações radiativas estão acontecendo na região de depleção, e por isso conseguimos visualizar a luminescência mais intensamente. Já a amostra 2-04-80 apresentou $\mathrm{n}=1,3$ indicando que apesar de haver recombinação radiativa na região de depleção, ela é predominante nas regiões $p$ e $n$, por isso, a luminescência é menos intensa, pois há maior probabilidade de haver reabsorção.

Na figura 5.11 temos duas células a 1-10-60 e a 2-10-80. Neste caso temos uma corrente de $4 \mathrm{~mA}$ aplicada na célula 1-10-60 e na célula 2-10-80 está sendo aplicada uma corrente de 6,4 $\mathrm{mA}$.

Ao comparar estas células podemos observar que mesmo fornecendo uma corrente maior para a célula 2-10-80 esta não apresentou uma luminescência igual à da célula 1-10-60. Com este resultado observamos que a recombinação não radiativa está se sobrepondo à recombinação radiativa. O fato de precisar fornecer uma corrente maior para a célula de 2-10-80 para que esta apresente uma luminescência maior, corrobora com o fato de que a amostra 2-10-80 apresentou uma resistência em série maior que a amostra 1-10-60.

Os resultados aqui apresentados estão de acordo com os resultados apresentados das demais técnicas, pois as amostras que apresentaram os 


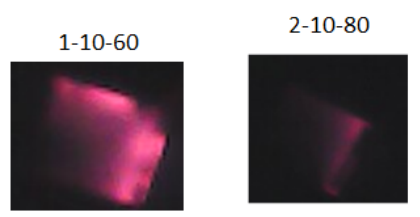

Figura 5.11: Eletroluminescência das células 1-10-60 e 2-10-80. Cada amostra foi excitada com uma corrente diferente, corrente essa necessária apenas para luminescer. A amostra 1-10-60 possui $60 \mathrm{~nm}$ no emissor e foi processada no LabSem, já a amostra 2-10-80 possui $80 \mathrm{~nm}$ no emissor e foi processada no LNMS.

maiores valores de resistência em série e os menores valores de resistência shunt (2-08-60 e 2-07-120) não apresentaram luminescência. Este fato indica que as recombinações não radiativas estão predominando em relação as recombinações radiativas.

No caso das amostras 1-08-60 e 2-04-80 podemos ver que as recombinações radiativas são predominantes e este resultado corrobora com o fato de que estas amostras apresentaram melhores figuras de mérito. Conforme esperado, a amostra 1-08-60 processada no LabSem apresentou uma luminescência mais intensa, pois esta foi a amostra que forneceu maior corrente.

A amostra 2-04-80 apresentou luminescência, porém, em intensidade menor. Podemos atribuir essa baixa intensidade à resistência em série que esta amostra apresentou cujo valor é maior em relação ao da amostra 1-08-60. 


\section{6}

\section{Conclusões e trabalhos futuros}

O objetivo deste trabalho foi apresentar um novo design otimizado para a célula de InGaP a fim de que haja o casamento de corrente com as demais células que compõem a célula de tripla junção.

A densidade de corrente encontrada através da simulação do dispositivo, juntamente com as demais figuras de mérito obtidas, estão de acordo com nosso objetivo. Desta forma, podemos concluir que a estrutura simulada é capaz de compor a célula de tripla junção.

Os resultados da caracterização das células solares nos permitiram entender o funcionamento dos dispositivos fabricados. Observamos que as figuras de mérito obtidas a partir da caracterização das células processadas no LabSem, exceto pela baixa corrente, foram semelhantes à simulação. A baixa corrente fornecida está associada tanto à dopagem da camada de BSF que não atingiu o valor esperado, quanto à resistência em série apresentada pelos dispositivos.

Os dispositivos processados no LNMS apresentaram uma corrente de saturação alta, o que fez com que a $V_{o c}$ fosse menor. Portanto, concluímos que é necessário aperfeiçoar a fabricação dos dispositivos, a fim de encontrar figuras de mérito de acordo com o que foi simulado.

Em relação ao crescimento das camadas do dispositivo, exceto o BSF, as demais camadas apresentaram boa qualidade cristalina, ótica e elétrica. Quanto ao processamento do dispositivo, as etapas de fotolitografia e metalização apresentaram bons resultados. Entretanto, na etapa de corrosão encontramos problemas com a taxa de corrosão e com sua uniformidade. A partir disso, podemos concluir que é necessário melhorar esta etapa do processamento, a fim de diminuir as resistências em série associadas e com isso aumentar a corrente fornecida. Além disso, melhorando o processamento, é possível diminuir a corrente de saturação a fim de aumentar a $V_{o c}$.

Como resultado desta dissertação, conseguimos produzir a primeira célula solar de InGaP do Laboratório de Semicondutores (LabSem). Na produção desta célula foram envolvidos diversos processos dentro das etapas de crescimento, processamento e caracterização, que possibilitaram um grande aprendizado, além de fornecer uma visão geral de como se dá a fabricação de um dispositivo fotovoltaico. 
Como trabalhos futuros, medidas de resposta espectral e eletroluminescência quantitativa são necessárias para que seja possível entender ainda mais sobre os mecanismos de recombinação e a eficiência quântica do dispositivo. 


\section{Referências bibliográficas}

[1] INTERNATIONAL ENERGY AGENCY. World energy outlook 2017. Technical report, International Energy Agency, 2017.

[2] KABIR, E.; KUMAR, P.; KUMAR, S.; ADELODUN, ADEDEJI A.; SESHADRI, V.; KIM, KI-HYUN. Solar energy: Potential and future prospects. Renewable and Sustainable Energy Reviews, 82:894-_900, 2018.

[3] MICHA, D. N.; JUNIOR, R. T. S.; ROCHA, B. V.; SILVA, D. A.; ALMEIDA, L. B.. O atual desafio energÉtico-ambiental mundial e a energia solar fotovoltaica. Revista Tecnologia Cultura, 31:77-86, 2018.

[4] VALLÊRA, M. A.; BRITO, C. M.. Meio século de história fotovoltaica. Technical Report 10 - 15, Faculdade de Ciências da Universidade de Lisboa, 2006.

[5] CHAPIN, D. M.; FULLER, C. S.; PEARSON, G. L.; A new silicon p-n junction photocell for converting solar radiation into electrical power. Journal of Applied Physics, 25:676, 1954.

[6] BAILEY, S. G.; FLOOD, D. J.. Space photovoltaics. Prog. Photovolt. Res. Appl., 6:1-14, 1998.

[7] SHOCKLEY, W.; HANS, J. Q. Detailed balance limit of efficiency of p-n junction solar cells. Journal of Applied Physics, 32:510 - 519, 1961.

[8] YAMAGUCHI, M.. Multi-junction solar cells and novel structures for solar cell applications. Physica E, 14:84-90, 2002.

[9] LUQUE, A.; MARTÍ, A.. The intermediate band solar cell: Progress toward the realization of an attractive concept. Advanced Materials, 22:160-174, 2010.

[10] TIBBITS, T.N.D.; BEUTEL, P.; GRAVE, M.; KARCHER, C.; OLIVA, E.; SIEFER, G.; WEKKELI, A.; SCHACHTNER, M.; DIMROTH, F.; BETT, A.W.; KRAUSE, R.; PICCIN, M.; BLANC, N.; MUÑOZ-RICO, M.; ARENA, C.; GUIOT, E.; CHARLES-ALFRED, C.; DRAZEK, C.; JANIN, F.; FARRUGIA, 
L.; HOARAU, B.; WASSELIN, J.; TAUZIN, A.; SIGNAMARCHEIX, T.; HANNAPPEL, T.; SCHWARZBURG, K.; DOBRICH, A.. New efficiency frontiers with wafer-bonded multi-junction solar cells. In: 29TH EUROPEAN PHOTOVOLTAIC SOLAR ENERGY CONFERENCE AND EXHIBITION, Amsterdam, 2014.

[11] NATIONAL RENEWABLE ENERGY LABORATORY, NREL. Best research-cell efficiencies. Photovoltaic Research, 2018. Acesso em: Maio de 2018.

[12] HECHT, J.. Photovoltaics takes small steps on journey to greater efficiency. PHOTONIC FRONTIERS: HIGH-EFFICIENCY PHOTOVOLTAICS, 2012. Acesso em: Setembro de 2018.

[13] LUQUE, A.; HEGEDUS S.. Handbook of Photovoltaic Science and Engineering. John Wiley Sons, Ltd, Instituto de Energía Solar, Universidad Politécnica de Madrid, Spain and Institute of Energy Conversion, University of Delaware, USA, second edition edition, 2011.

[14] ABREU, R. A. S. DE. CaracterizaÇÃo elÉtrica de cÉlulas solares de tripla junÇÃo-gainp/gaas/ge. Dissertação de mestrado, Instituto Nacional de Pesquisas Espaciais, São José dos Campos, 2006.

[15] MICHA, D. N.; SOUZA, P. L.; COSTA, E. W.; CUNHA, V. R.; SAKAMOTO, R. M. S.; PINTO, L. D.; PIRES, M. P.; HERCULANO, E. P.; KLEIN, N. Y.. Desenvolvimento de células solares de múltiplas junções para aplicações espaciais no laboratório de semicondutores da pucrio. In: VII CONGRESSO BRASILEIRO DE ENERGIA SOLAR, Gramado, 2018.

[16] WINTER, E.; MICHA, D. N.; KLEIN, N. Y.; PIRES, M. P.; SOUZA, P. L.. Simulation of ingaas/ingap multiple quantum well systems for multijunction solar cell. In: 33RD SBMICRO 2017, Fortaleza, 2017.

[17] REZENDE, S. M.. Materiais e Dispositivos Eletr^onicos. Editora Livraria da Física, São Paulo, 2nd edition, 2004.

[18] STREetman, B. G.. Solid State Electronic Devices. Prentice-Hall, Inc., USA, 4th edition, 1995.

[19] FREIRE, C. A. S.; CARVALHO, P. C. M.. Comparação de dois modelos de células fotovoltaicas usando dados reais: modelo de dois diodos versus modelo de um diodo e quatro parâmetros. In: ENCONTRO DE ENERGIA NO MEIO RURAL, Campinas, 2000. 
[20] COMSOL. Software de modelamento. COMSOL Multiphysics, 2018. Acesso em: Setembro de 2018.

[21] ELIS, UNIVERSITY OF GENT. Simulation programme scaps-1d for thin film solar cells. Simulation programme SCAPS-1D for thin film solar cells, 2018. Acesso em: Setembro de 2018.

[22] BURGELMAN M.; DECOCK K.; NIEMEGEERS A.; VERSCHRAEGEN J.; DEGRAVE S.. SCAPS manual. Manual maio, 2018, Department of Electronics and Information Systems of the University of Gent, 2018.

[23] BURGELMAN M.; NOLLET P.; DEGRAVE S.. Modelling polycrystalline semiconductor solar cells. Thin Solid Films, 361-362:527-532, 2000.

[24] ABDERREZEK, M.; FATHI, M.; DJAHLI, F.; AYAD, M.. Numerical simulation of luminescent downshifing in top cell of monolithic tandem solar cells. Internation Journal of Photoenergy, 2013:1-7, 2013.

[25] NAYAK, P. P.; DUTTA, J. P.; MISHRA, G. P.. Efficient ingap/gaas dj solar cell with double back surface field layer. Engineering Science and Technology, an International Journal, 18:325-335, 2015.

[26] TAKAMOTO, T.; IKEDA, E.; KURITA, H.; OHMORI, M.. Structural optimization for single junction ingap solar cells. Solar Energy Materials and Solar Cells, 35:25-31, 1994.

[27] HOBSON, W. S.. Epitaxial growth, properties and device applications of algainp. In: WIDE BANDGAP SEMICONDUCTORS AND DEVICES, p. 26-41, USA, 1995.

[28] OHBA, Y.; ISHIKAWA, M.; SUGAWARA, H.; YAMAMOTO, M.; NAKANISI, T.. Growth of high-quality ingaaip epilayers by mocvd using methyl metalorganics and their application to visible semiconductor lasers. Journal ofCrystal Growth, 77:374—379, 1986.

[29] GEISZ, J. F.; STEINER, M. A.; GARCIA, I.; KURTZ, S. R.; FRIEDMAN, D. J.. Enhanced external radiative efficiency for $20.8 \%$ efficient single-junction gainp solar cells. Applied Physics Letters, 103:1-5, 2013.

[30] KAWABATA, R. M. S.. Produção e caracterização de fotodetectores de infravermelho baseado em poços quânticos com duas geometrias distintas de acoplamento com a luz. Dissertação de mestrado, 
Departamento de Engenharia Elétrica, Pontifícia Universidade Católica do Rio de Janeiro, Rio de Janeiro, 2011.

[31] FOLLSTAEDT, D. M. AND SCHNEIDER, JR., R.P. AND JONES, E.D.. Ordering and phase separation in mocvd ingap alloys and unicompositional quantum wells. In: PRESENTED AT THE FALL MEETING OF THE MATERIALS RESEARCH SOCIETY (MRS), Boston, MA, 1993.

[32] HAYASHI, A. M.; MARCON, R.. High resolution x-ray diffraction to characterize semiconductor materials. Revista Physicae, 1:21-27, 2000.

[33] MOURÃO, R. M.. Crescimento e caracterização de materiais e nanoestruturas semicondutores para aplicação em células solares. Dissertação de mestrado, Instituto de Física, Universidade Federal do Rio de Janeiro, Rio de Janeiro, 2013.

[34] HALL, E.. On a new action of the magnet on electric currents. American Journal of Mathematics, 2:287-292, 1880.

[35] VAN DER PAUW, L.J.. A method of measuring the resistivity and hall coefficient on lamellae of arbitrary shape. Philips Technical Review, 20:220-224, 1958.

[36] NOLDIN, J. H. Contribuição ao estudo da cinética de redução de briquetes autoredutores. Dissertação de mestrado, Departamento de Engenharia Elétrica, Pontifícia Universidade Católica do Rio de Janeiro, Rio de Janeiro, 2015.

[37] SCHUBERT, F.E.. Light-Emitting Diodes. E. Fred Schubert, Rensselaer Polytechnic Institute Troy, New York, USA, third edition edition, 2018.

[38] MADELUNG, O.. Semiconductors: group IV elements and IIIV compounds. Springer-Verlag, Druckhaus Langenscheidt KG, Berlin Germany, first edition edition, 1991.

[39] MATTHEWS, J. W.; BLAKESLEE, A. E.. Defects in epitaxial multilayers. Journal of Crystal Growth, 27:118-125, 1974.

[40] PHOTOVOLTAIC EDUCATION, PVE. Dark iv measurements. Dark IV Measurements, 2018. Acesso em: Setembro de 2018.

[41] ZHANG, L.; NIU, P.; LI, Y.; SONG, M.; ZHANG, J.; NING, P.; CHEN, P.. Investigation on high-efficiency ga0.51in0.49p/in0.01ga0.99as/ge 
triple-junction solar cells for space applications. AIP Advances, 7:118-125, 2017.

[42] KING, D. L.; HANSEN, B. R.; KRATOCHVIL, J. A.; QUINTANA, M. A.. Dark current-voltage measurements on photovoltaic modules as a diagnostic or manufacturing tool. In: 26TH IEEE PHOTOVOLTAIC, California, 1997.

[43] BREITENSTEIN, O.; ALTERMATT, P.; RAMSPECK, K.; SCHENK, A.. The origin of ideality factors $n>2$ of shunts and surfaces in the dark i-v curvas of si solar cells. In: 21TH EUROPEAN PHOTOVOLTAIC SOLAR ENERGY CONFERENCE, p. 625-628, Dresden, 2006. 


\section{Software de simulação}

Na tela inicial do SCAPS, apresentado na figura A.1, temos as configurações iniciais, que estão numeradas:

1- Working point: local do programa onde é configurada a condição de operação do dispositivo que será levada em consideração na simulação, por exemplo, a temperatura;

2- Ilumination: onde são feitas as configurações sobre a luz. Destacam-se as possibilidades de fazer a simulação iluminada ou não, qual lado do dispositivo será iluminado (isto ficará mais claro adiante quando for falado sobre a montagem da célula), e nesta opção é onde ficam armazenados os espectros;

3- Action: são as opções de medidas que podem ser simuladas e suas configurações pertinentes;

4- Os botões de configuração e simulação: set problem, onde é configurada estrutura do dispositivo; single shot, opção de fazer apenas uma rodada com a estrutura definida, batch, traz a possibilidade de fazer uma bateria de simulações variando um ou mais parâmetros e recorder, modo que utiliza a configuração do batch porém, em vez de apresentar apenas as curvas $I V$, o usuário pode configurar quais parâmetros deseja salvar.

5- Os botões que direcionam para as páginas específicas de cada resultado.

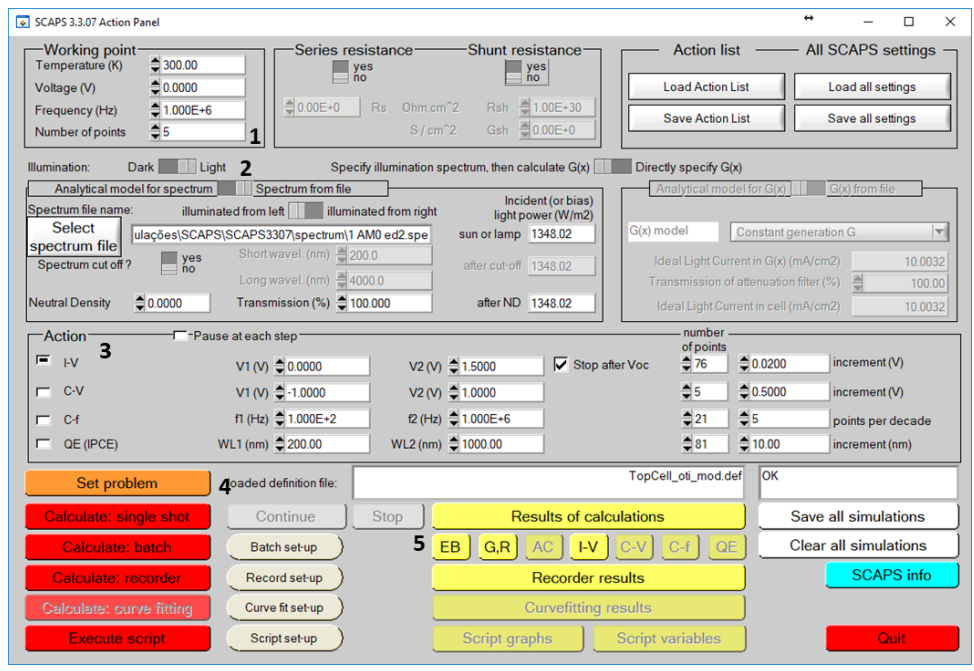

Figura A.1: Tela inicial do software SCAPS, onde são feitas as configurações gerais das condições nas quais o dispositivo ira operar. 
A definição da estrutura a ser utilizada pode ser feita ao clicar em set problem.

A figura A.2 apresenta a tela de configuração, onde estão numeradas as principais opções para a montagem do dispositivo.

1- Local onde são inseridas as camadas que compõem o dispositivo, a ordem, interfaces e também as configurações dos contatos.

2- Local onde pode ser configurado: local de aplicação tensão e se o dispositivo é um gerador de corrente. Também é possível marcar por onde será iluminado o dispositivo (conforme mencionado no tópico ilumination).

3- A representação gráfica do dispositivo montado na parte 1 da janela. Aqui estão representadas também a entrada da luz e a natureza dos contatos elétricos, ou seja, onde é aterrado e onde se pode ler a tensão.

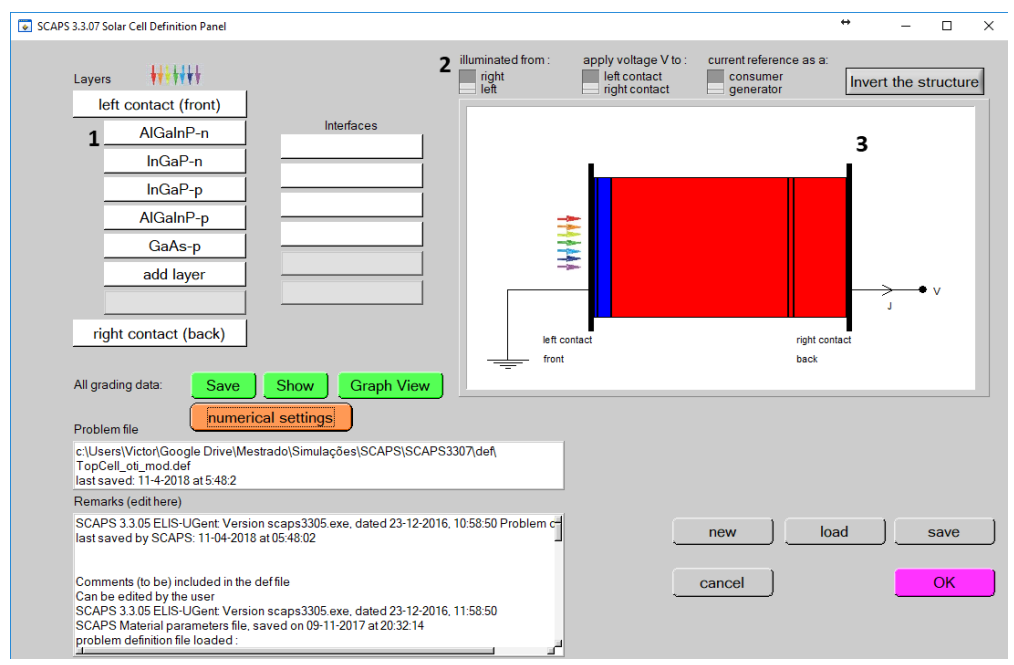

Figura A.2: Nesta tela é possível adicionar as camadas que compõem a célula e configurar a natureza elétrica dos contatos.

Ao inserir uma camada e clicar sobre a mesma, o usuário tem a acesso à janela de configuração do material, que está apresentada na figura A.3. À esquerda, há uma lista com os parâmetros que podem ser configurados pelo usuário a fim de delinear o material a ser trabalhado. Na parte de baixo, ainda à esquerda, está disponível para configuração o modelo de absorção a ser utilizado, podendo partir de um arquivo ou seguir um modelo padrão. À direita, temos na parte de cima os valores de recombinação que podem ser configurados, e na parte de baixo da tela é possível adicionar defeitos à estrutura do material.

Tendo já configurado os parâmetros iniciais e modelado a célula, pode-se então rodar uma ou várias simulações dependendo da opção escolhida.

No caso de uma única simulação, após os cálculos finalizados, os resultados são apresentados de acordo com a figura A.4 que mostra a curva $I V$ 


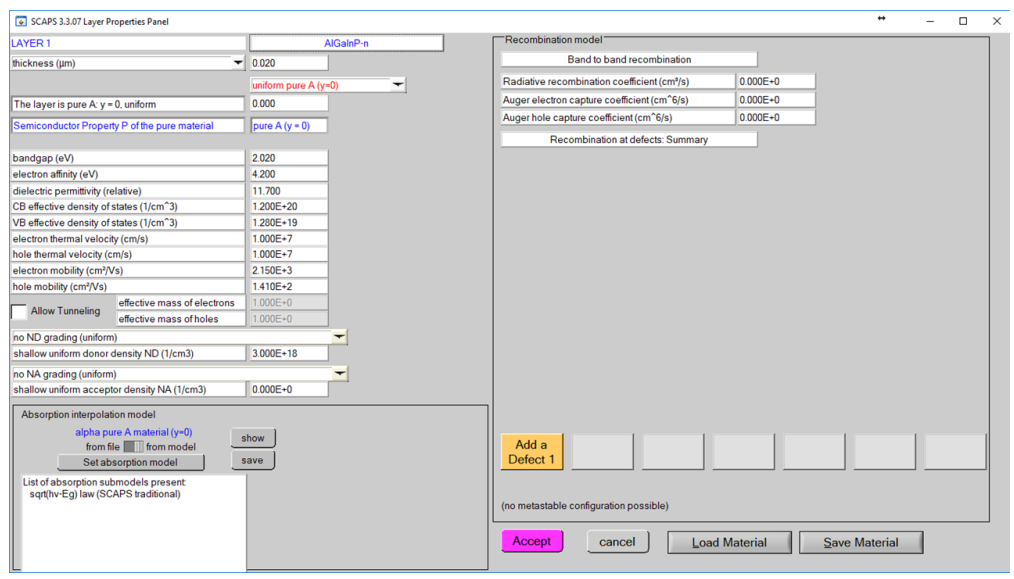

Figura A.3: Nesta tela é possível configurar as características do material adicionado.

obtida, e abaixo dela as figuras de mérito.

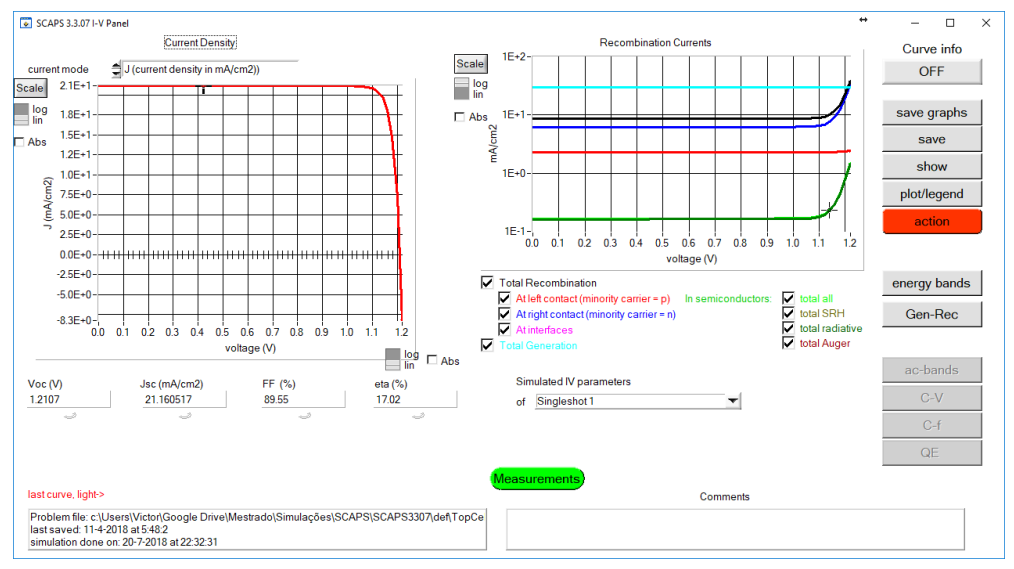

Figura A.4: Tela de apresentação do resultado da simulação.

Outra possibilidade é fazer uma bateria de simulações. Esta opção pode ser configurada na janela apresentada na figura A.5. Nesta janela podemos colocar o material juntamente com o parâmetro e o intervalo a ser variado. A configuração das baterias permite que os parâmetros sejam variados simultaneamente ou de forma independente. Ou seja, podemos variar somente a espessura ou variar espessura e dopagem na mesma bateria.

Os resultados da bateria de simulações são apresentados de maneira semelhante à figura A.4, porém, em vez de uma única curva $I V$, todas as curvas simuladas são apresentadas dentro da mesma área do gráfico. Esta maneira de apresentar os resultados não acrescenta muito na análise dos dados, pois não é possível visualizar com clareza como foi o comportamento do parâmetro variado.

A opção Record permite que sejam escolhidas características a serem gravadas pelo programa, no intuito de melhorar a apresentação dos resultados. Essas opções podem ser configuradas na tela apresentada na figura A.6, onde é 


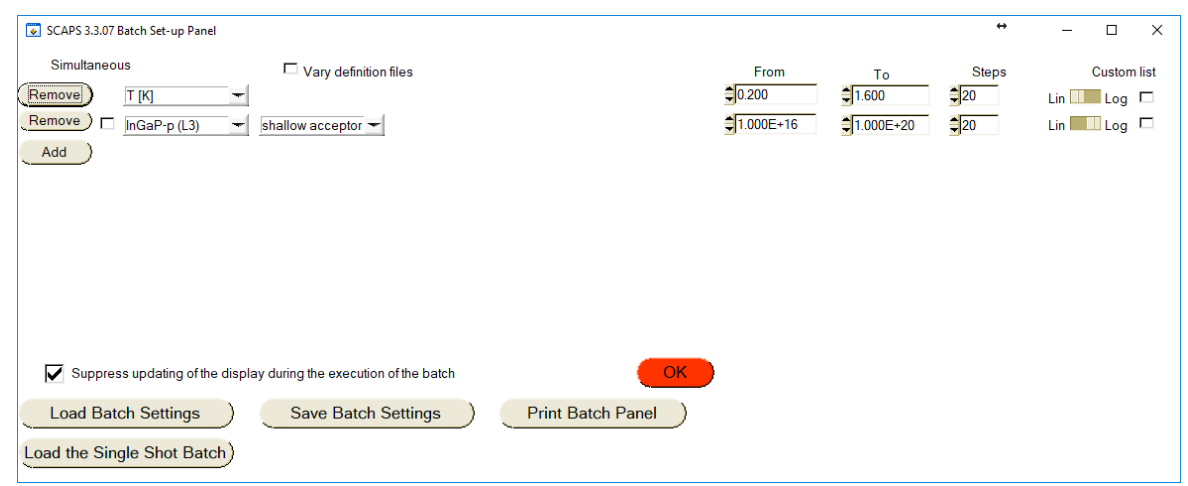

Figura A.5: Nesta tela é possível configurar uma bateria de simulações.

apresentada uma lista com os parâmetros a serem salvos e à direita é possível escolher as opções dentre os diversos resultados disponíveis. É preciso ressaltar que o Record só funciona a partir de um batch configurado.

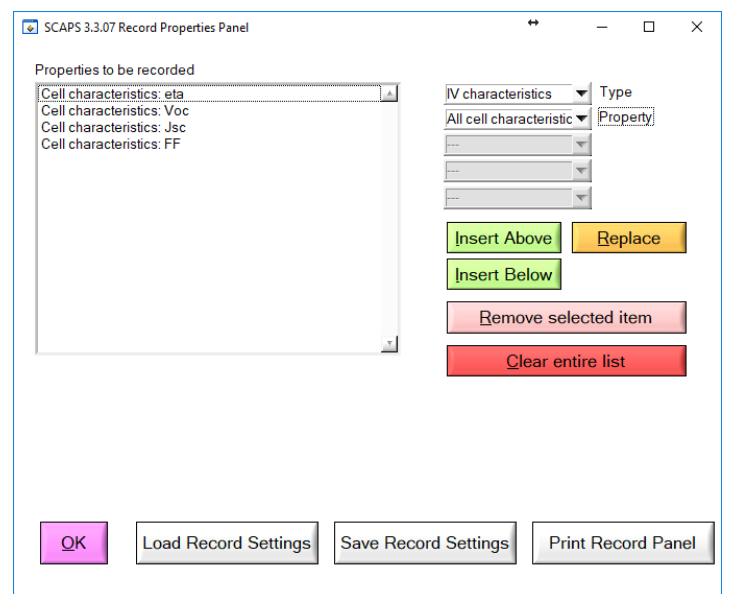

Figura A.6: Nesta tela é possível configurar as figuras de mérito à serem gravadas durante a simulação.

Após as baterias de simulações, se utilizada, a opção Record, os resultados são apresentados como na janela apresentada na figura A.7. Nesta janela o resultado é apresentado do seguinte modo: o eixo x contém o parâmetro variado, por exemplo, a espessura; e o eixo y contém as figuras de mérito, por exemplo, a $\mathrm{J}_{s c}$.

Seguindo estes breves passos é possível configurar uma simulação no SCAPS. No próximo tópico falaremos sobre como o programa resolve o sistema de equações. 


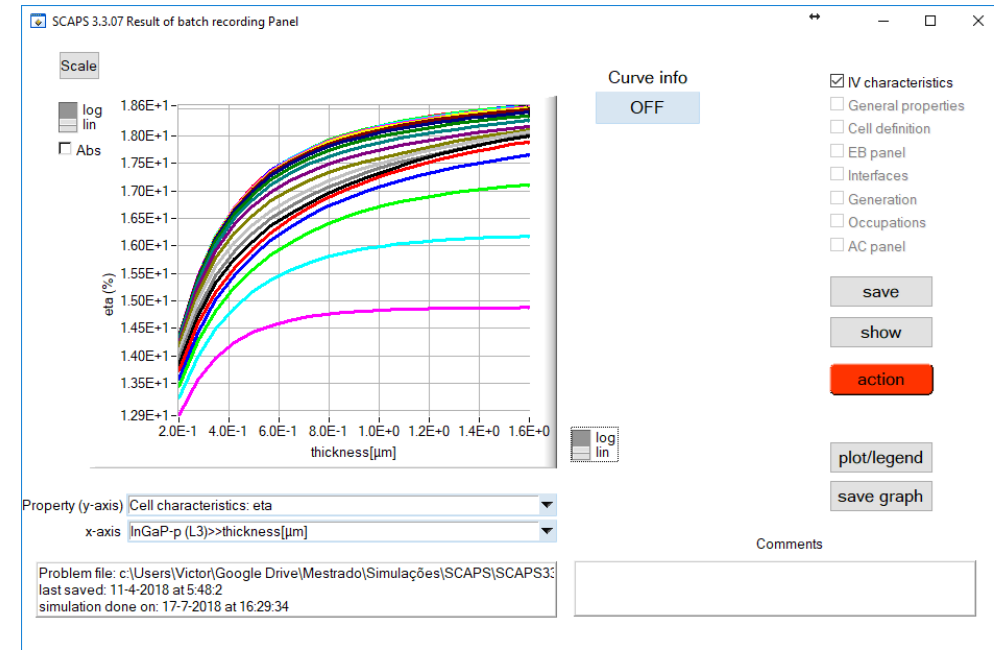

Figura A.7: Tela onde são apresentados os resultados obtidos no record da simulação. 
B

\section{Processamento}

\section{Formulário de processamento LABSEM}

Processamento $\mathrm{n}^{0}$ : Data:

Autor: Operador:

Amostras:

Objetivo:

Substrato: $\square \mathrm{GaAs} \quad \square \ln \mathrm{P} \quad \square \mathrm{Si} \quad \square \mathrm{Ge} \quad \square$ Outro:

$\underline{\text { Resumo: }}$ ฉ Limpeza $₫$ Fotolitografia $\square$ Metalização: $\square$ Tratamento térmico $\square$ Corrosão:

๑ Deposição: $\square$ Eletrodeposição $\square$ Processamento completo:

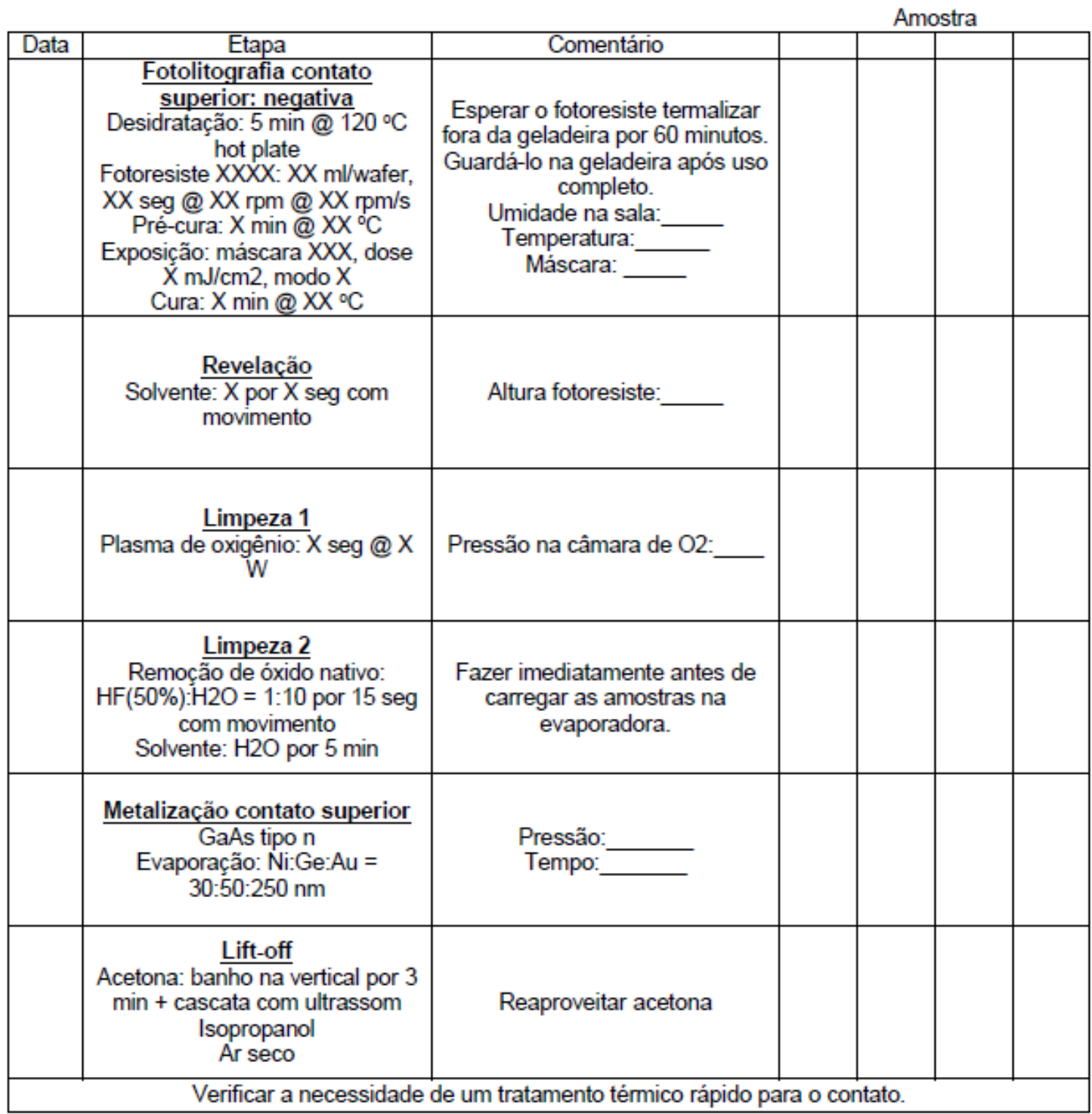




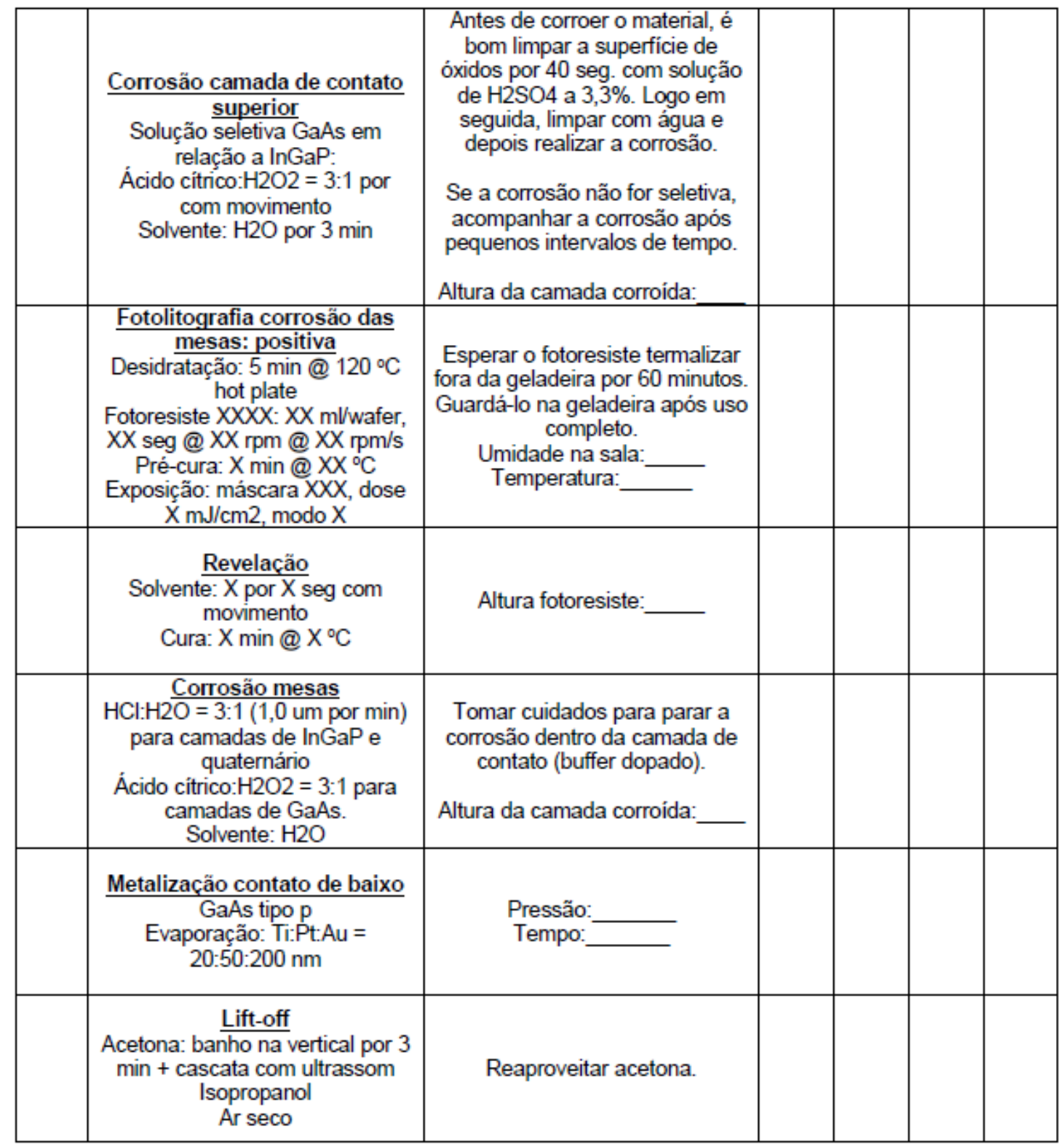

